\title{
The Origins of Urban Society
}

\section{I INTRODUCTION}

During the formative stage of ancient Egyptian culture, towns gradually emerged that already showed some of the characteristics of urban society, which became standard during the later Pharaonic period and continue to evolve over several millennia. The archaeological evidence from various sites located in different regions of Egypt, from the southern border town of Elephantine in Upper Egypt to the settlement at Buto in the northwestern Delta, shows remarkable indications for the beginnings of urban society (Figure 4.I). This is also the time frame during which the early Egyptian state was formed.

The archaeological evidence from these settlement sites is quite incomplete, and in most cases only small areas and exposures of a few structures have been excavated. However, it is possible to get some insight into the earliest development of the larger towns as well as a glimpse concerning their layouts, which also allows for a first evaluation of the characteristics of these earliest Egyptian settlements. The study of Predynastic and Early Dynastic Egypt has received increased scholarly attention since the I970s, but in comparison with the archaeological evidence from the Pharaonic period, there is still much less data available. This is to some extent related to the preservation of the archaeological evidence, much of it having been affected by high groundwater levels as well as covered by thick layers of alluvium or later settlement. A noticeable surge over the past ten years in excavations focusing on the earliest phases of ancient Egyptian civilization can be noted for the Nile Delta region, where a number of new sites have been excavated - such as Tell el-Farkha and Tell Ibrahim Awad, but also Tell Iswid (Figure 4.I). ${ }^{\mathrm{I}}$ Much of this work is still in progress. Given the incomplete nature of the preserved evidence from settlements, only a tentative evaluation of these sites can be given here; nevertheless, the evidence gathered is a start with which new archaeological results can be integrated in the future. The following analysis has the aim of bringing together several key aspects such as the emergence of mud-brick architecture, the appearance of buildings of official character, early sanctuaries, and trends in the more general development of early towns - for which Hierakonpolis is the prime example because it has been excavated and surveyed in much detail (Figure 4.I). By analyzing the excavated settlement remains, even if they only present a small portion of the whole settlement, it is possible to obtain an initial picture of what characterized and constituted these earliest towns and their inhabitants. This picture, in turn, provides a first opportunity to trace the beginnings of urban society in ancient Egypt.

\subsection{THE FIRST APPEARANCE OF URBAN ELEMENTS}

The formative period for the ancient Egyptian civilization, culminating in the inception of a politically unified territorial state around 3 IOO BCE and the following Early Dynastic Period, set in motion many of the traditions that later became so typical for the Pharaonic period. The emergence of complex settlement systems showing the first urban characteristics gradually appeared in the Nile Valley as well as the Delta region during the late Naqada II period (Naqada IIC-D, Table 4.I). It also indicates that, in the case of Egypt, a unified state was not a prerequisite for the emergence of urbanism. ${ }^{2}$

Even though our archaeological record is far from being complete, a number of urban elements can already be recognized at the end of the Naqada II period that will gradually become the dominant features of ancient 


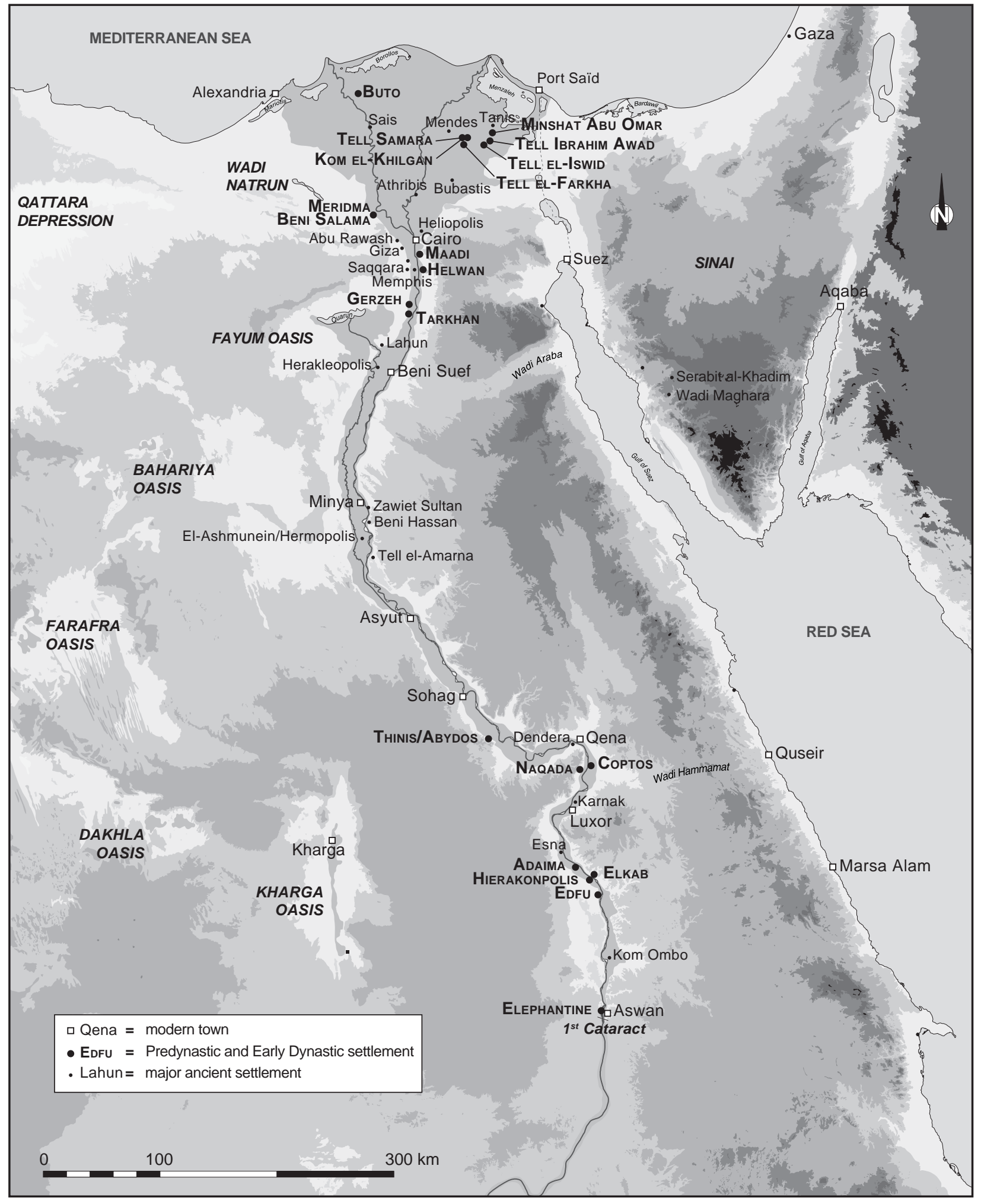

4.I. Map of Predynastic and Early Dynastic sites in Egypt. By G. Marouard. 
TABLE 4.I. Chronology of Predynastic and Early Dynastic Egypt

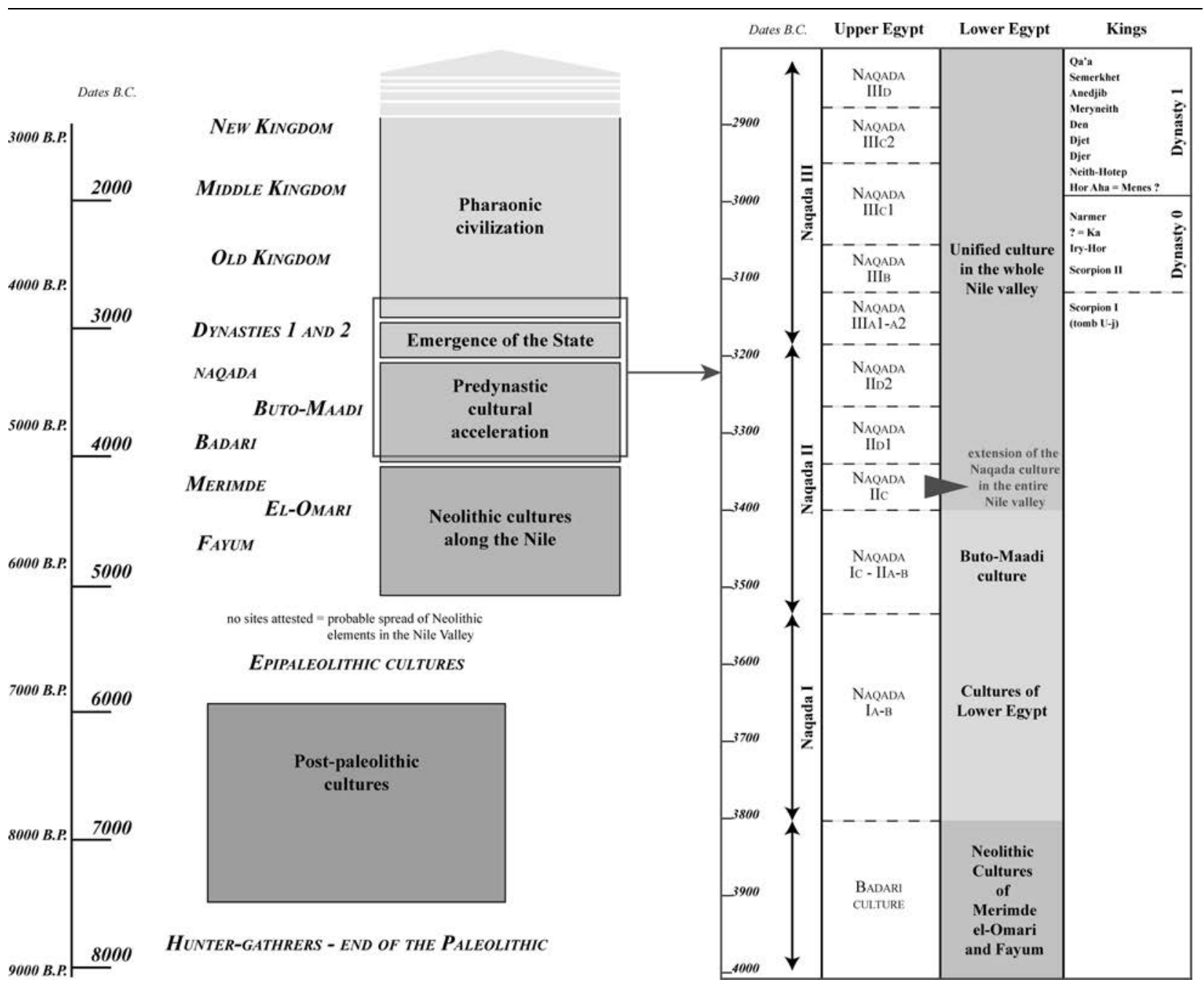

By G. Marouard, after B. Midant-Reynes, Aux Origines de l'Égypte. Du Néolithique à l'émergence de l'État, Paris 2003 , tab. I and 2.

Egyptian towns during the Early Dynastic Period. The latter is characterized by the appearance of local sanctuaries and temples, designated production and manufacturing areas along the settlement margins, hierarchies among buildings according to size and layout, and "palatial" complexes that functioned as the residence of the local chief but also seem to have held an important economic/administrative and even cultic function. There is, in addition, evidence for fortified enclosure walls during this formative stage of ancient Egyptian history. ${ }^{3}$ At the same time, elaborate cemeteries showing increasing social differentiation appeared in the vicinity of the settlements.

The choice of sites that will be discussed in depth in this chapter is mainly based on the availability of detailed archaeological data. With the exception of the case of Hierakonpolis, the archaeological evidence presented here dates to the late Predynastic and the Early Dynastic Periods. ${ }^{4}$ Hierakonpolis deserves a fuller treatment because of its continuous occupation from the early Predynastic Period to the late Old Kingdom, and in this respect it has much to offer in terms of a wider analysis of settlement patterns and the general evolution during these earliest phases of Pharaonic civilization.

Certain elements that are a prerequisite for urban development started to appear during the transition from the latter part of the Predynastic into the Early Dynastic Period. From the late Naqada II period onward (ca. 3400 BCE, see Table 4.I), it is possible to observe a gradual trend 

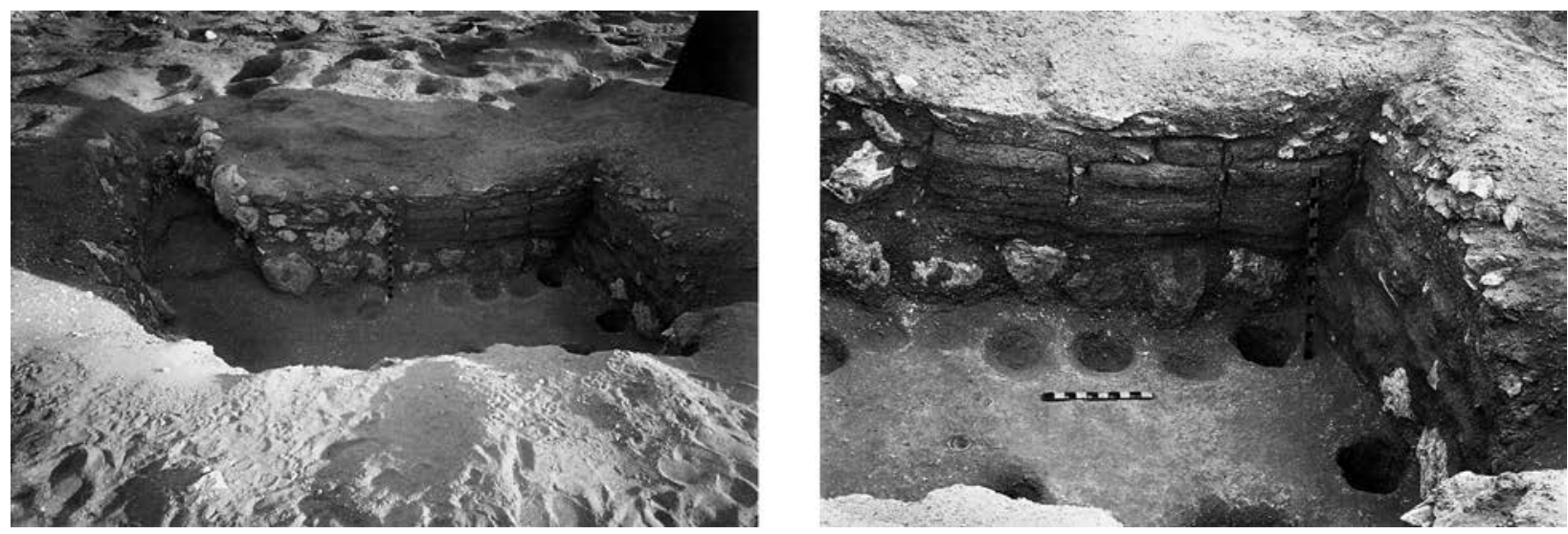

4.2. Semisubterranean house at Maadi and detail of the mud-brick wall (Buto-Maadi culture). After I. Rizkana J. Seeher, Maadi III. The Non-Lithic Small Finds and the Structural Remains of the Predynastic Settlement, AV 80, I989, pl. XV I, 2. C) Deutsches Archäologisches Institut, Kairo.

toward more-nucleated settlement with higher population densities, increasing craft specialization, and the existence of a network engaged in long-distance trade. ${ }^{5}$ Certain traits, such as the appearance of specific production areas, for example larger breweries, which are possibly also linked to the first emergence of the division of labor, appear already in the earlier Naqada II period. ${ }^{6}$ During the same time, growing social complexity is witnessed, especially by the appearance of elite cemeteries displaying variations in rank, but this remains less visible in the settlements where no real differences can be seen in terms of size or layout of individual structures. An early example of a kind of monumental building of ceremonial nature has been found at Hierakonpolis, at Locality 29A, which dates to late Naqada II/early Naqada III, but no real large-scale mud-brick or stone architecture seems to have existed here until the Early Dynastic Period. ${ }^{7}$

It is the time frame between the emergence of a unified territorial state and a certain level of cultural unity for all of Egypt - starting around the Naqada IIIA2 period (= Dynasty o, see Table 4.I) and evolving rapidly during the Early Dynastic Period - that appears to be the most formative period for the development of ancient Egyptian towns and cities. Among those elements and features that first become visible in the archaeological record during this time period (Dynasty o/Naqada IIIA-B) are:

I. Rectangular buildings made entirely of mud brick

2. Specific manufacturing and production areas along the settlement margins

3. Ceremonial centers and early temples/shrines
4. Appearance of buildings of administrative/official character as well as "palatial" structures

5. Large enclosure walls with various functions demarcating large building complexes of official, palatial, and ceremonial nature as well as serving as fortifications

\subsection{The appearance of mud-brick architecture}

The predominant building material employed in settlements was sun-dried mud brick, ${ }^{8}$ the use of which appears during the earlier culture of Buto-Maadi (ca. 3600 BCE; see Table 4.I) in the Delta, where mud brick is attested for the foundations of semisubterranean houses together with a stone and mortar construction (Figures 4.2 and 4.3). ${ }^{9}$ These earliest traces of the use of mud brick as a building material for domestic architecture appear in a settlement area where seemingly "foreign" types of houses have been uncovered - notably several subterranean constructions that resemble buildings from the Beersheva culture in the southern Levant (Figures $4.4 \mathrm{a}$ and b). ${ }^{\text {IO }}$ There is a good chance that the technique of mud-brick construction has Levantine origins, which would also fit with the earlier appearance in northern Egypt, before its use is attested in the south. ${ }^{\text {II }}$ At the Upper Egyptian site of Hierakonpolis, the sporadic use of mud brick in combination with stones set in mud mortar and upper walls made with the wattle-and-daub technique $^{\mathrm{I2}}$ date to the early Naqada II period, about Ioo years later than its first appearance at Maadi (ca. 3500 BCE; see Table 4.I). The use of mud brick is also attested for tomb architecture in the same time period. ${ }^{13}$ 


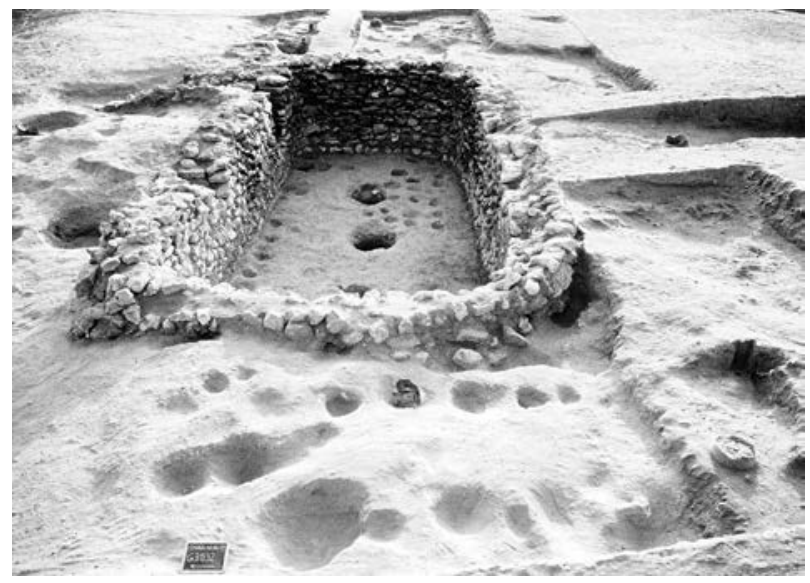

4.3. Semisubterranean house with stone wall at Maadi (ButoMaadi culture). After U. Hartung, "Puzzlearbeit zwischen Neubauten: Neue archäologische Untersuchungen in Maadi," in G. Dreyer, D. Polz (eds.), Begegnung mit der Vergangenheit100 Jahre in Ägyten, 2007, I27, Abb. I73. (C) Deutsches Archäologisches Institut, Kairo.

Although it is possible to observe that the beginnings of adobe architecture in Egypt are strongly linked to domestic buildings, its usage is also known to have been quickly adopted for the construction of funerary architecture. ${ }^{I 4}$ This observation indicates an increasing preference for mud brick as a building material, which had the advantage of relatively cost-effective and quick production as well as being adapted to the hot climate. Its adoption for tomb architecture was probably motivated by similar considerations but also suggests that tombs might have been to some extent modeled on houses and already conceptualized as "house of the dead" during the Predynastic period. By the Early Dynastic Period, mud brick was established as the principal building material in settlements and also widely employed for funerary architecture - in some cases even on a monumental scale, as can be witnessed by the royal tombs and funerary enclosures at Abydos as well as the elaborate elite tombs at Saqqara. ${ }^{\text {IS }}$

The long-term focus on funerary architecture has led to a considerable bias in the archaeological data in relation to what is available for the earliest settlements - a situation similar to what is seen for the later Pharaonic period. This makes any intersite comparison difficult, and one is often confronted with seemingly unique buildings that do not have any comparisons elsewhere, such as the "palace façade" structure at Hierakonpolis or the large building complex of the Early Dynastic Period excavated at Buto (Figures 4.26 and 4.32). The latter had been first

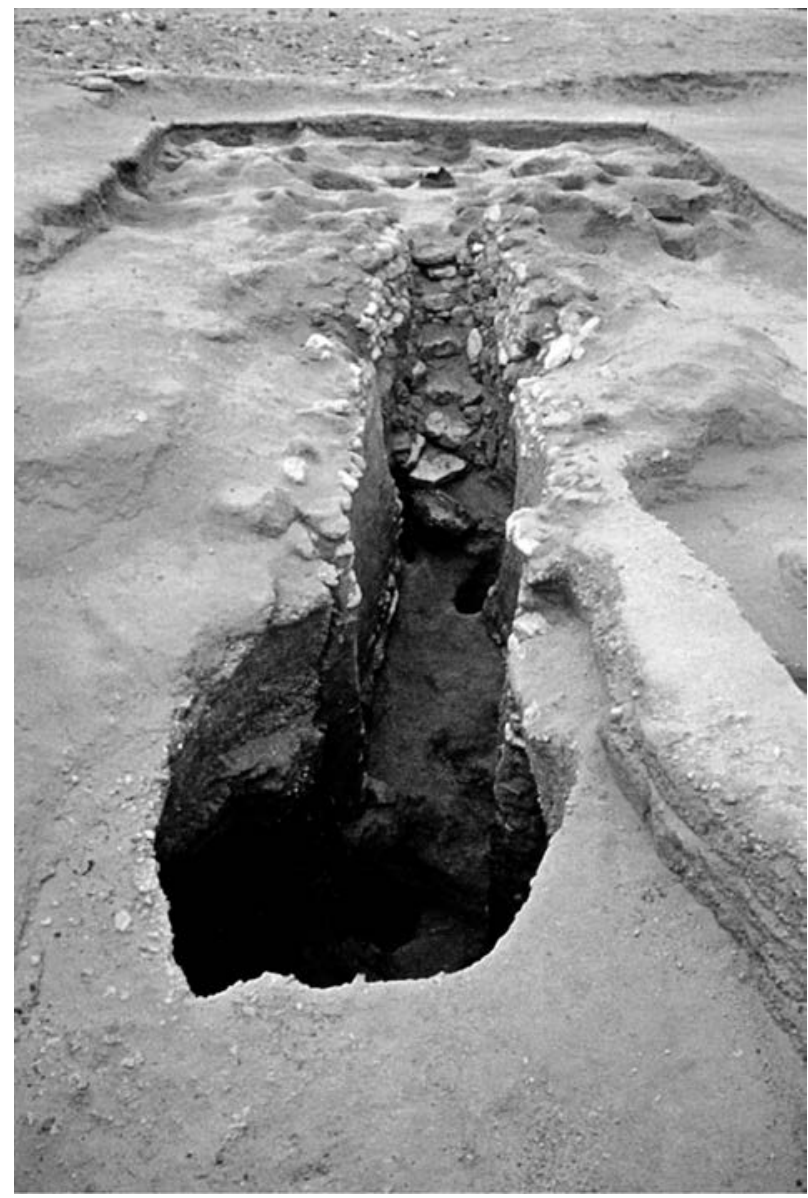

4.4a. Subterranean building at Maadi (Buto-Maadi culture). After U. Hartung, "Puzzlearbeit zwischen Neubauten: Neue archäologische Untersuchungen in Maadi," in G. Dreyer, D. Polz (eds.), Begegnung mit der Vergangenheit - 100 Jahre in Ägypten, 2007, I28, Abb. 175. (C) Deutsches Archäologisches Institut, Kairo.

interpreted as a funerary or cult complex because of the organization of doorways according to the bent-axis principle that also occurs in mortuary architecture. This view was later corrected. ${ }^{16}$

In the past, scholars frequently attempted to draw comparisons between domestic and funerary architecture because little else was available. It is important to realize that the origins of many architectural forms and traditions in Egypt have their roots in the settlement context, even though this context is often less well known in comparison with funerary and cult architecture. It is evident that certain forms and styles were quickly adopted in the latter and then developed further into their own tradition. ${ }^{17}$ For example, the layout of the large mud-brick tomb $U_{-j}$ at the early cemetery at Abydos (belonging to a late 


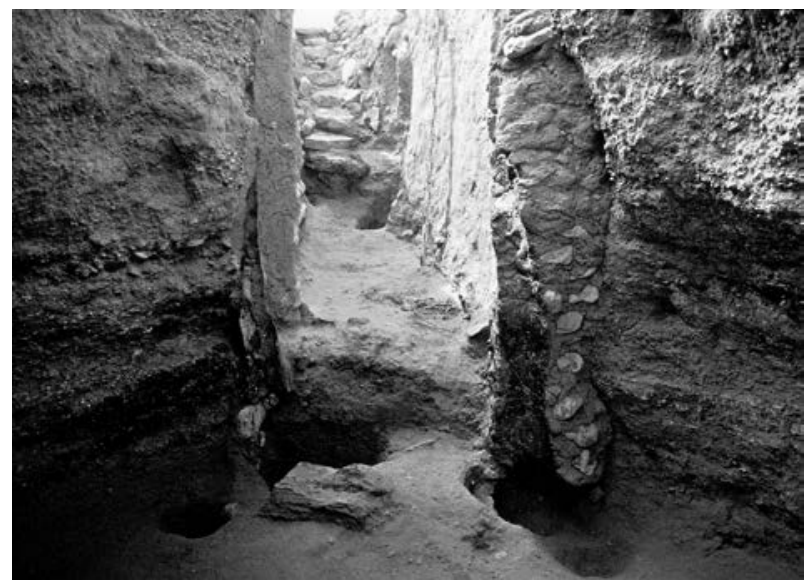

4.4b. Entrance to the subterranean building at Maadi. After U. Hartung, "Puzzlearbeit zwischen Neubauten: Neue archäologische Untersuchungen in Maadi," in G. Dreyer, D. Polz (eds.), Begegnung mit der Vergangenheit - 100 Jahre in Ägypten, 2007, I28, Abb. I75. (C) Deutsches Archäologisches Institut, Kairo.

Predynastic ruler) has been interpreted as a model of a palatial building that was transposed into the funerary sphere. ${ }^{18}$ However, it is necessary to exercise caution when comparing buildings from settlement contexts directly with funerary architecture, because both spheres clearly developed according to their own trajectories.

\subsubsection{Evidence for domestic buildings of rectangular layout}

The current archaeological evidence shows the presence of buildings with rectangular walls made entirely of mud brick from the Naqada IIC/Di period onward. ${ }^{19}$ They appear first quite sporadically in the north and south, and do not replace the previously existing building techniques such as wattle-and-daub and wooden constructions.

In the Delta, sites such as Buto/Tell el-Far'ain, Tell elFarkha, and Tell Ibrahim Awad (Figure 4.I) provide some evidence for complete buildings that show more than just the occasional mud-brick wall fragment. Mudbrick construction seems to appear increasingly in the archaeological record from the end of Naqada IID to early Naqada IIIA onward. The gradual introduction of mud bricks at Buto as the principal building material starts during the transitional settlement phase of IIIa-f, which is also equated with the beginning of the dominance of the Upper Egyptian Naqada culture at the settlement. ${ }^{20}$ The first full outline of a rectangular mud-brick building is visible in Phase IIId, which dates to the Naqada IIIA period at about $3200 \mathrm{BCE}$ (see Table 4.I). At least four rooms can be distinguished, the largest one being $2.8 \mathrm{~m}$ wide and $7.6 \mathrm{~m}$ long (Figure 4.5). ${ }^{2 \mathrm{I}}$ The associated finds are not providing any indications as to the use of this building - for example, whether it was domestic or official in character.

At the site of Tell el-Farkha in the eastern Delta, fully identifiable mud-brick houses appeared about the same time as in Buto, with comparable dimensions (Figure 4.6). ${ }^{22}$ Excavations in the southern part of the Central Kôm revealed elongated mud-brick rooms built around an open courtyard (Figure 4.7). The rooms measure $3.5 \mathrm{~m}$ in width and are about $\mathrm{IO} \mathrm{m}$ long. They have been dated to the Naqada III period. ${ }^{23}$ These settlement remains have been interpreted as a service complex according to the presence of kilns, hearths, and numerous storage installations such as grain silos. Evidence for administrative activity comes from the discovery of a cylinder seal. ${ }^{24}$ The same phenomenon has also been noticed at Tell Ibrahim Awad, where entire mud-brick structures are present from stratum 6 onward. ${ }^{25}$

In the south, the evidence is less clear, which is partly due to less settlement sites having been excavated. The evidence from the Naqada-period settlement remains at the island of Elephantine, situated in the First Cataract region, shows the first appearance of mud-brick buildings during Naqada IIICI, thus slightly later than in the Delta but of comparable dimensions and layout. ${ }^{26}$ The walls of this rectangular house are relatively thin, only one mud brick thick; and to its southern side, several postholes indicate the presence of a yard-like area demarcated by a wooden fence (Figure 4.8) ${ }^{27}$ This is also from the time when the first mud-brick wall was erected in front of the natural niche between the basalt boulders, which functioned as an early shrine and later developed into the temple dedicated to the local goddess Satet.

At the site of Hierakonpolis, ancient Nekhen, the evidence for the appearance of mud-brick buildings is less known. Although broken bricks were already used for the foundation of the house excavated in Locality HK 29 (Figure 4.22), dating to the beginning of the Naqada II period, complete rectangular house structures made entirely of mud brick from before the Early Dynastic Period have not been excavated. This is mainly related to the problem of high groundwater level at the site of ancient Nekhen, situated in the floodplain, which made it impossible for the excavators to carry out a larger-scale excavation. Michael Hoffman dug a Io $\mathrm{m} \times$ Io $\mathrm{m}$ square (IoN5 W; see Figure 4.25) at the settlement mound of 

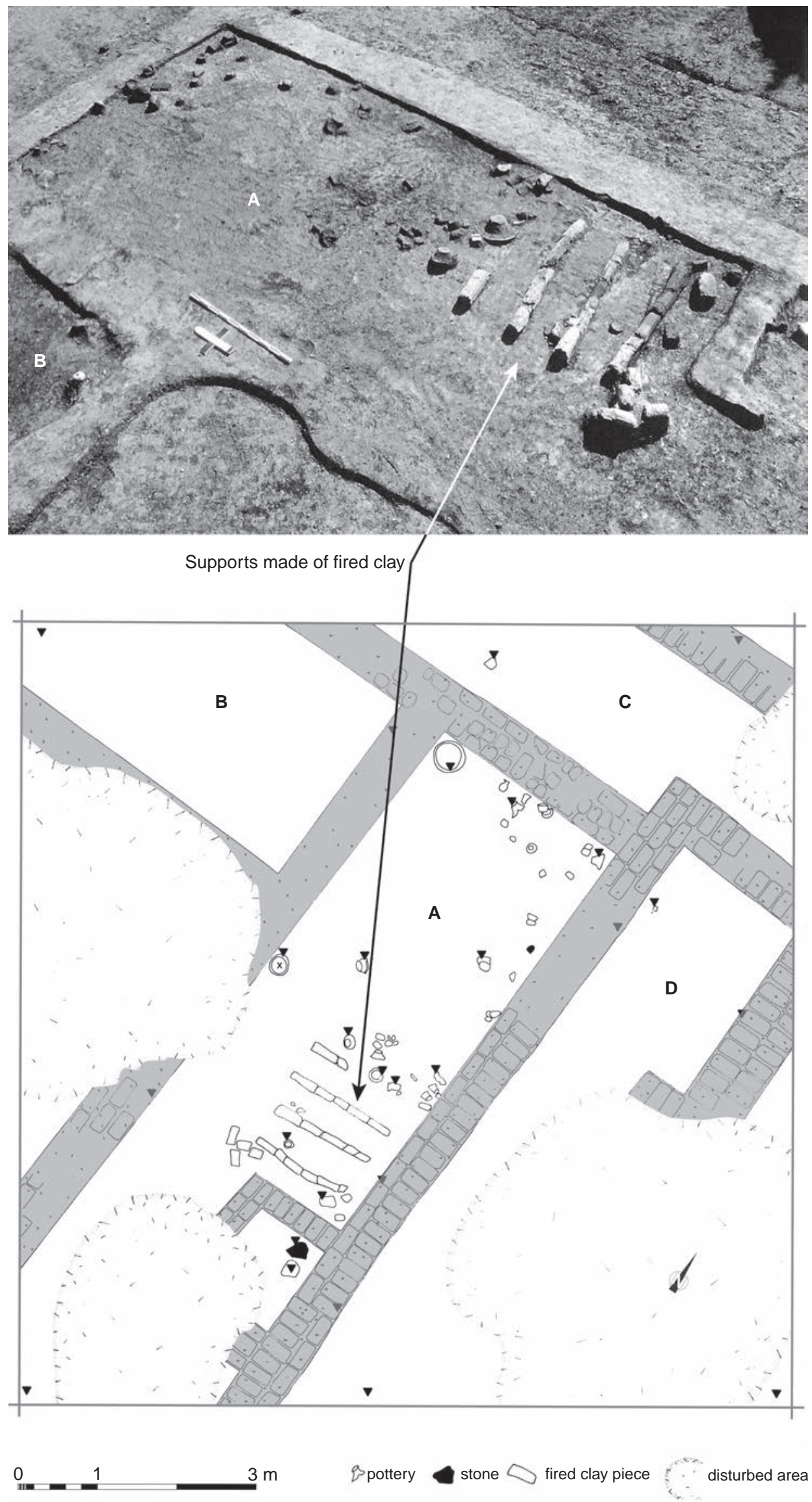

4.5. Mud-brick building, Phase IIId (Naqada IIIA period), at Buto. After T. Von der Way, Tell el-Fara'in-Buto I. Ergebnisse zum frühen Kontext. Kampagnen der Jahre 1983-1989, AV 83, I997, I I9, Abb. 62 and Tf. IXa. C Deutsches Archäologisches Institut, Kairo. 


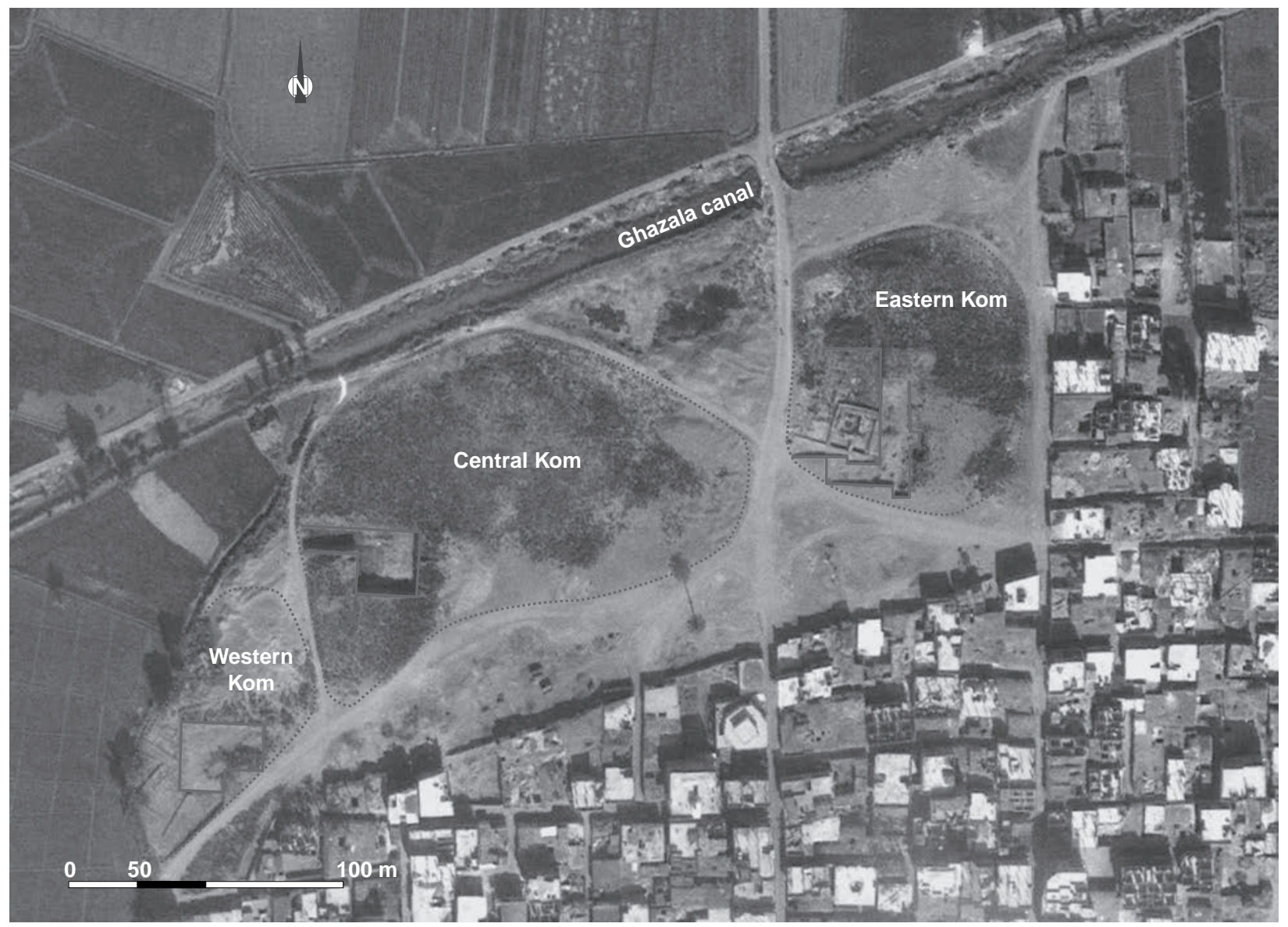

4.6. Satellite view (2009) of the archaeological area at Tell el-Farkha. By G. Marouard, using Google Earth ${ }^{\mathrm{TM}}$, image (C) $20 \mathrm{I} 4$ DigitalGlobe.

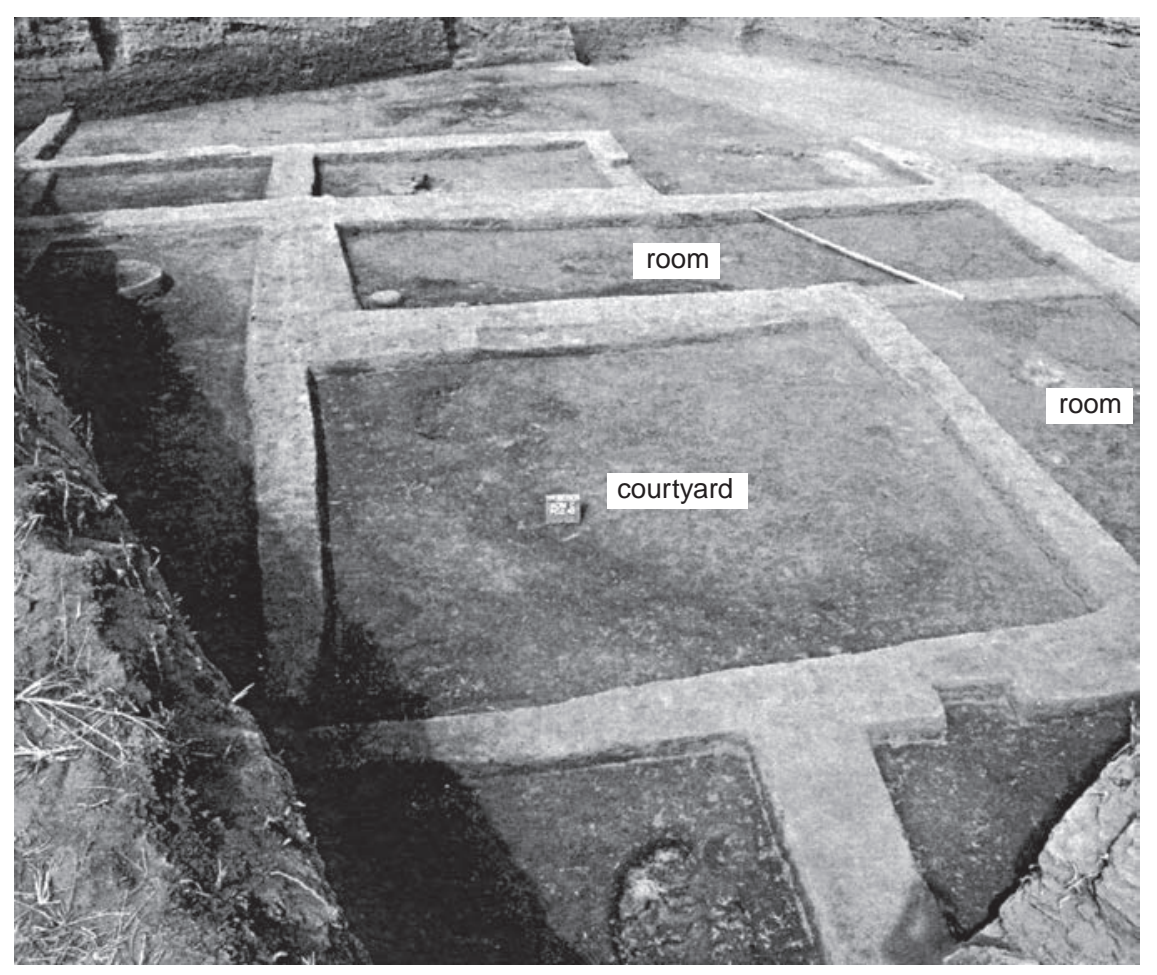

4.7. Mud-brick buildings (Naqada III period), at Tell el-Farkha. After M. Chłodnicki and K. M. Ciałowicz, "Tell El-Farkha (Ghazala): Season 2005," PAM I7 (2005), I48, fig. 5. Courtesy M. Chłodnicki and K. M. Ciałowicz. 


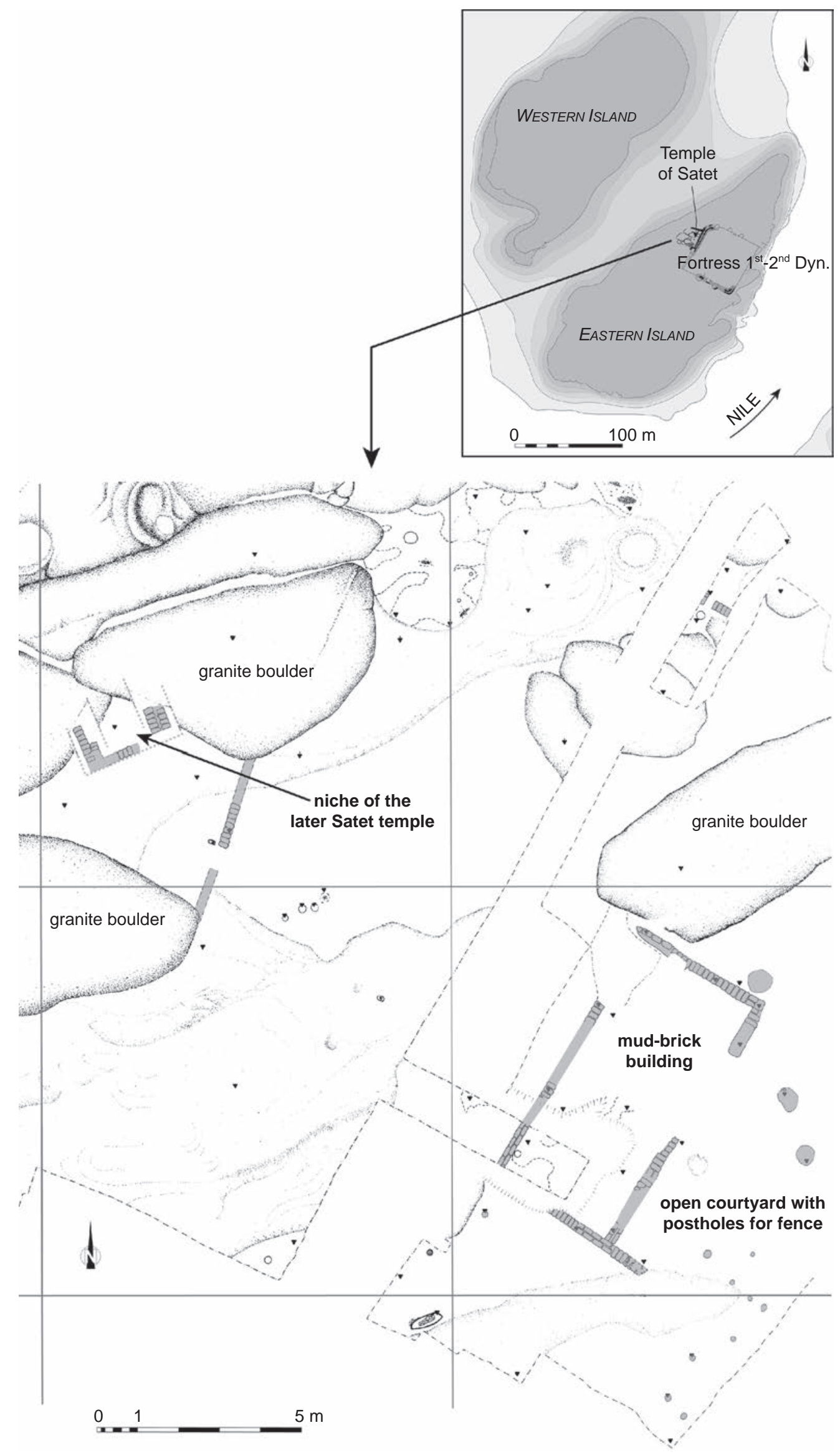

4.8. Mud-brick structures in the area of the later Satet temple (Naqada IIICI period), at Elephantine. By G. Marouard, after P. Kopp, Elephantine XXXII. Die Siedlung der Naqadazeit, AV I I 8, 2006, Abb. I5. 
Kôm el-Gemuwia, where he found a complete stratigraphic sequence of Predynastic to Early Dynastic settlement layers. Not enough was exposed to identify any larger buildings, apart from a house built in the wattleand-daub technique standing next to a thick mud-brick wall ( $3 \mathrm{~m}$ wide) of unknown function dating to the Naqada III period. ${ }^{28}$ Thus evidence for the emergence of full mud-brick buildings remains difficult to fully assess at this site.

More evidence but unfortunately less clearly datable was found by William Flinders Petrie and James Quibell at the site of Naqada - ancient Nubt - that is associated during later periods with the worship of Seth. The site is situated on the west bank of the Nile in the Qena bend region (Figure 4.9). While excavating a large Predynastic cemetery, remains of a substantial building complex were found at the so-called South Town area. The plan was published only as a sketch showing several mud-brick walls belonging to rectangular buildings that were surrounded by a substantial wall with a thickness of about $2 \mathrm{~m}$ (Figure 4.9). The preserved sections of this perimeter wall enclose an area of $34 \mathrm{~m}$ by $50 \mathrm{~m}$, but the full extent is not known, and it is also not entirely clear whether the wall was enclosing the settlement or an important building complex (see Figure 4.9). ${ }^{29}$ Later fieldwork at the site found no traces of the wall nor the structures on its inside, which must have been destroyed by the extensive sebakh digging that affected much of the ancient settlement. From this reinvestigation, a chronological framework for the Prehistoric cemetery and settlement at Naqada was much more firmly established and showed a continuous occupation from the Naqada I period onward. ${ }^{30}$ The buildings Petrie and Quibell excavated seem to be of late Naqada II/early Naqada III date. ${ }^{31}$

As can be seen from the various examples presented here, the comparison of mud-brick buildings of domestic character from different sites and regions in Egypt shows that there is some variation as to their sizes and layouts, and there seems to be neither any kind of house type(s) that can be recognized nor any specific hierarchy among the buildings of each settlement. In areas where a larger extent of the early settlement was uncovered, it is possible to observe smaller rooms in the front giving access to a larger, rectangular, hall-like room in the back.

In most cases it has been difficult to distinguish the various rooms that belonged to a single structure, because all that is visible on the plans are walls forming rooms that are built against each other in an agglutinated way, without any clearly demarcated building boundaries. The term "agglutinated" is used here with reference to the fashion in which buildings were constructed and organized within a given settlement. An agglutinated form of settlement is characterized by a multitude of mud-brick buildings that share common walls; rooms have been added consecutively against each other without showing any distinct organizational pattern. Individual houses and even streets or pathways are difficult to recognize in an agglutinated settlement layout. This seems to be one of the main characteristics of settlements dating from the end of the fourth millennium BCE well into the third millennium BCE in Egypt.

\subsubsection{Manufacturing and production areas along the settlement margins}

The archaeological evidence at Hierakonpolis shows the presence of specific parts within the wider settlement that were used for large-scale food production such as breweries and also for the manufacturing of stone and ceramics (see, for example, Figures 4.20 and 4.2I). These installations were clearly producing more than the demands of a single household. They start to appear during the second half of the fourth millennium BCE (ca. 3500/3400, Naqada IIA/B). ${ }^{32}$ The evidence for those installations is not restricted to Upper Egypt, however, but has also been discovered at the site of Tell el-Farkha in the eastern Nile Delta, where they belong to the Lower Egyptian culture (Figure 4.10). ${ }^{33}$ Three phases of breweries have been distinguished, and they were dated to about 3500-3350 BCE. ${ }^{34}$ Interestingly, there are also parallels in the layout of the breweries, which were equipped with large vats held up by firedogs at both sites. The large-scale exploration of the desert edge at Hierakonpolis has shown that these production and manufacturing sites were situated along the margins of the actual settlement. At Tell elFarkha this could also be the case when taking into account the regular flooding of brewery structures on the Western Kôm, where they were situated along its western side (Figure 4.Io). ${ }^{35}$

These installations provide first evidence for a certain division of labor and the possibility that some part of the inhabitants were not engaged full time in agricultural activities. For the brewery installations, it is likely that the people involved in beer brewing were supported by others in terms of food supply and ingredients, but more-practical issues need to be considered as well, such as the regular procurement of firewood. The appearance of specific workshops also dates to the time frame of the breweries. 


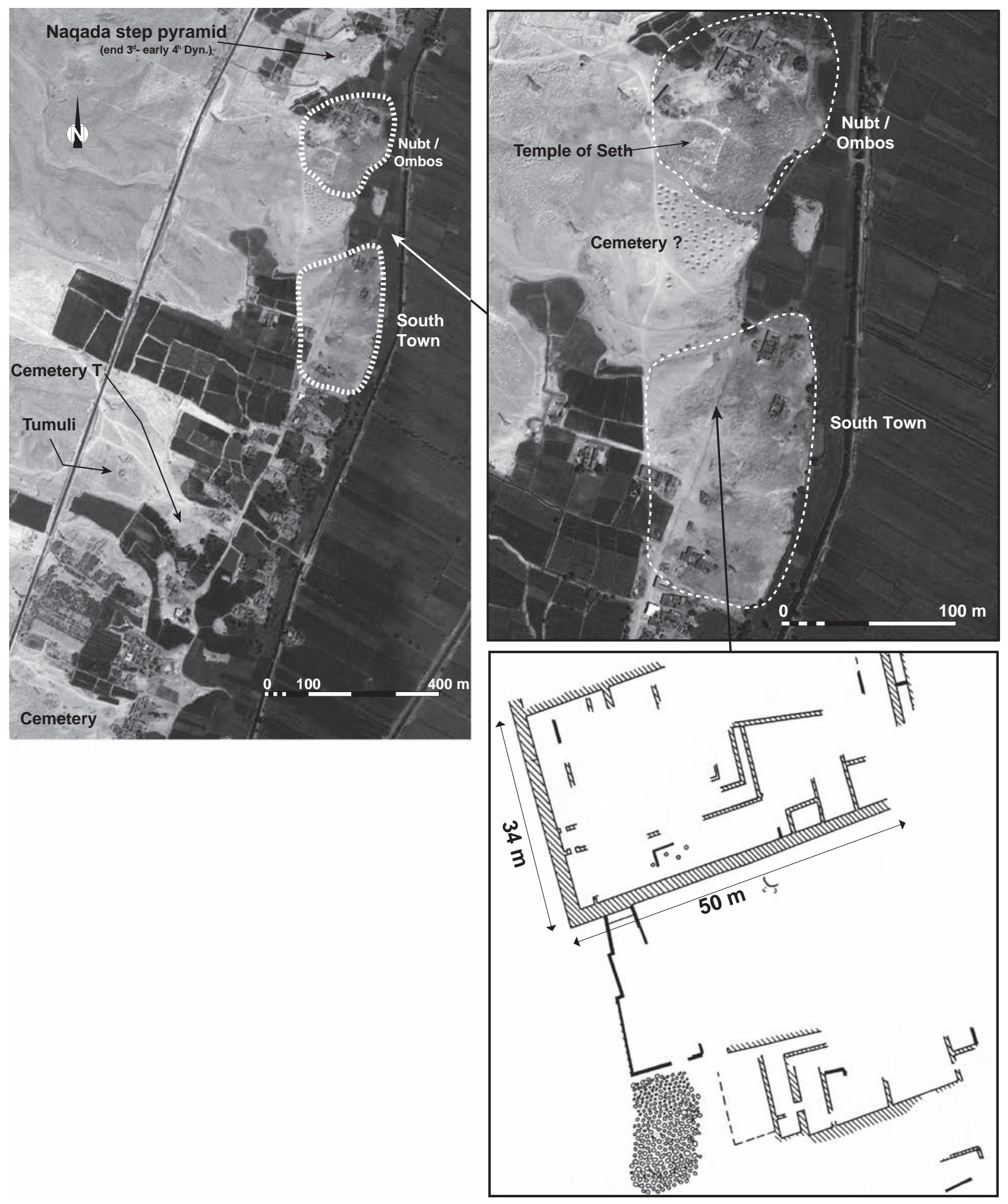

4.9. Satellite view (2006) of the archaeological area at Naqada and the South Town area at Nubt (late Naqada II-early Naqada III period). By G. Marouard, using Google Earth ${ }^{\mathrm{TM}}$, image C 2014 DigitalGlobe, and site plan after B. Kemp, Ancient Egypt, Anatomy of a Civilization, London/New York 2006, 79, fig. 24. 


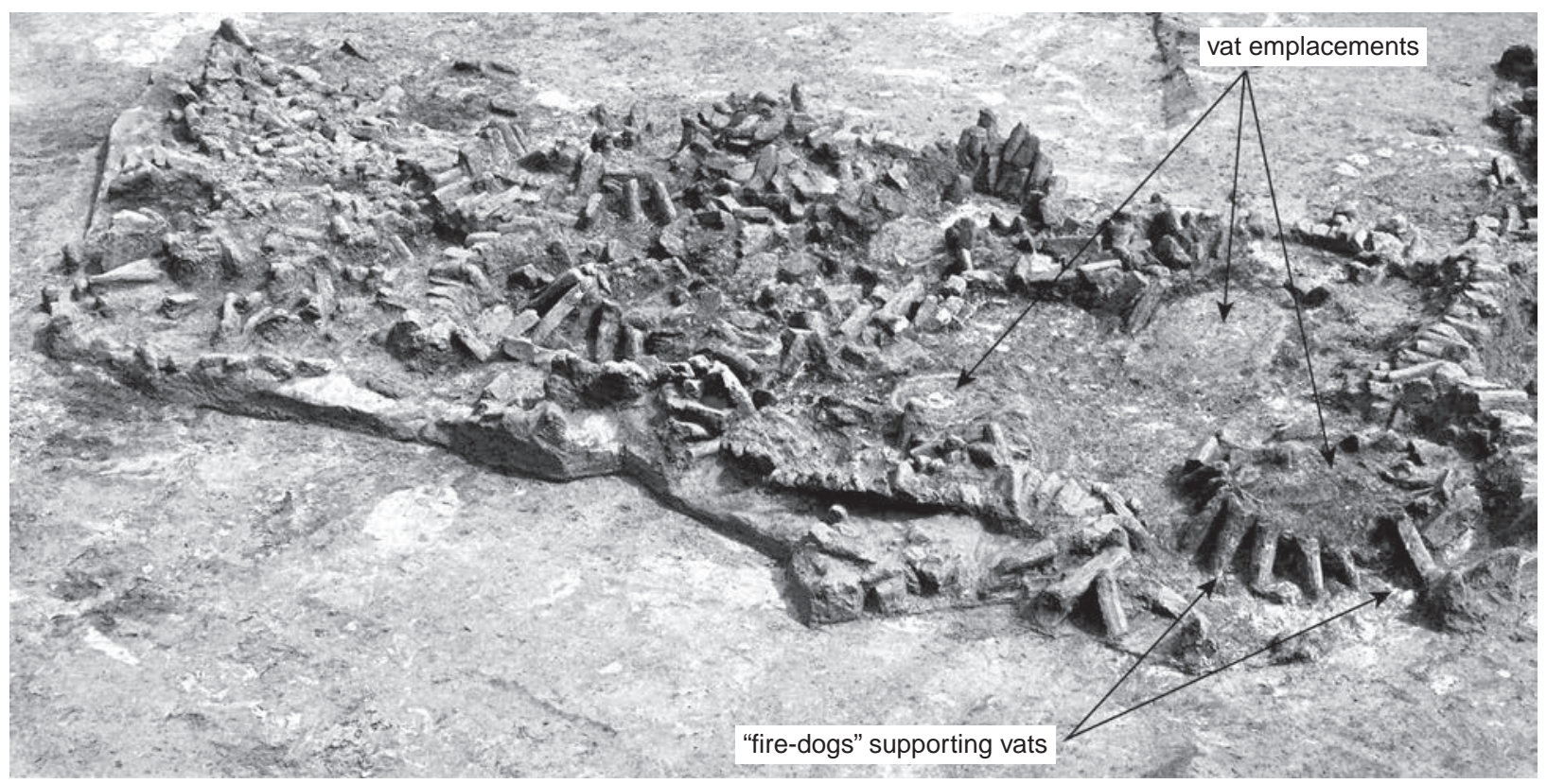

4.Io. First phase of breweries on the Western Kôm at Tell el-Farkha (Lower Egyptian culture). After K. M. Ciałowicz, "The Predynastic/Early Dynastic Period at Tell el-Farkha," in E. Teeter (ed.), Egypt before the Pyramids. The Origins of Egyptian Civilization, OIMP 33, 20I I, 57, fig. 6.2. Courtesy M. Chłodnicki and K. M. Ciałowicz.

At Hierakonpolis several pottery workshops have been identified that produced certain types of pottery. A production area along the Wadi Abu Suffian might have been related to the supply of the nearby elite cemetery, HK 6 (Figure 4.I8). ${ }^{36}$ This workshop is an interesting example for considering the possible purposes and functions of such installations, and it is situated along the south side of Wadi Abu Suffian, at about $300 \mathrm{~m}$ northeast of the elite cemetery. HK IIC is divided into two main areas of excavation: the pottery and beer production site (Operation $\mathrm{B}$ ) and, $20 \mathrm{~m}$ east of it, a much larger brewery installation (Operation A) (Figure 4.20). Dense scatter of broken pieces of pottery belonging to jars of the so-called straw-tempered rough-ware type have been found here and were obviously produced at the kiln site, as has been witnessed by a large amount of "wasters," sherds from misfired and often vitrified pottery vessels. This type of pottery was also found in tombs from the cemetery at HK 6. The archaeological evidence therefore shows clearly that this type of pottery was produced at the kilns located at HK I IC and then given as grave goods for the burials of the elite members of Hierakonpolis society during the early Naqada II period. When studied in depth, it turned out that these vessels were exclusively produced as funerary items for the elite tombs of the period, without ever being used. ${ }^{37}$ The nature of the pottery production site at Operation B has been commented on by the excavators as being more seasonal, with pottery production occurring as a lowintensity activity. ${ }^{38}$ The brewing facility in Operation $\mathrm{B}$, which consists of several vats, and the larger one at Operation A cannot be linked directly to the production of rough-ware jars, because beer was not stored in the vessels found. ${ }^{39}$ A question remains to be answered: What purpose was served by the large industrial brewery and food-producing installations at Operation A? There was certainly a connection with the elite cemetery, according to its location and the sheer amount of production capability. Evidence so far points to a more exclusive use for the cemetery. The presence of large wooden-columned halls near these tombs suggests that they were some kind of forerunner to the later "offering chapel." This is a fascinating piece of evidence in the evolutionary line of the ancient Egyptian mortuary cult. $^{40}$

\subsubsection{Evidence for early temples and ceremonial structures}

The Early Dynastic Period is also the time of the emergence of the so-called preformal temple buildings. ${ }^{4 I}$ 
Apart from Hierakonpolis, where a close link to the royal cult can be observed - for example, from the objects of the Main Deposit discovered at the temple at Kôm elGemuwia (see Figure 4.25 for location of the temple precinct) - other sites are much more obscure and resemble small, informal cult complexes and shrines. Even the worshipped deities are difficult to identify. However, what all these sanctuaries have in common are small votive figurines of animals and humans made of ivory or faience that were found in deposits utilized when these objects fell out of use and were ritually buried..$^{42}$ These earliest shrines are very informal in their layouts and were an integral part of the local community, which was responsible for the construction, supply, and functioning of the local cult. There is no evidence for these places of worship having received any attention by the central government before the end of the Old Kingdom. ${ }^{43}$ Nevertheless, they constitute an integral part of the emerging settlements and developed gradually into temples dedicated to the local town gods. One of the earliest ceremonial centers has been excavated at Locality HK $29 \mathrm{~A}$ at Hierakonpolis (Figure 4.23); it consists of a large oval courtyard flanked by four cedar beams probably used as flagstaffs during the ceremonies that were performed here. Excavations at Elephantine have revealed the location of the earliest shrine between the rock boulders of the eastern island, which formed a small niche (Figure 4.II). ${ }^{44}$ The development of this sanctuary from a small cave-like place of worship to the large formal temple buildings of Middle and New Kingdoms has been followed during the excavations. ${ }^{45} \mathrm{~A}$ large number of small votive objects from this place consist of ivory and faience figurines depicting various animals and human figures. Such figurines have been found at other sites even as far north as Tell el-Farkha and Tell Ibrahim Awad in the Nile Delta, indicating a remarkable similarity in the cultural expression for votive objects during the Early Dynastic period. ${ }^{46}$ At Tell Ibrahim Awad, a site located in the northeastern Delta, a sequence of shrines and small temples dating from the late Predynastic (Naqada IIIA/B) to the Middle Kingdom have been excavated (Figure 4.I2). The architectural remains show a similar development from informal local architecture to the more mature temple layout known from the Middle Kingdom onward, as can be witnessed at Elephantine. ${ }^{47}$ Only a few wall fragments remain of the earliest temple structure, and these outline a long, rectangular building measuring about $8.8 \mathrm{~m}$ in length and $3.5 \mathrm{~m}$ in width (Figure 4.I2).

\subsubsection{The archaeological evidence for "official" buildings}

The identification of official or administrative buildings remains difficult for these early periods. The earliest evidence for an administrative/official building complex has been excavated recently at Tell el-Farkha; the complex also served as a residence for the local elite. ${ }^{48}$ On the Western Kôm, a large building complex termed the "Naqadian residence" has been discovered for which two phases of construction can be distinguished: an earlier phase dating to the Naqada IID2/Naqada IIIAI period and later phase belonging to the Naqada IIIA2 period. The exceptionally large dimensions of this complex covering more than $500 \mathrm{~m}^{2}$ and built with substantial mud-brick walls, some of which measure between $2.5 \mathrm{~m}$ and $\mathrm{I} \mathrm{m}$ in width - distinguish it as one of the largest-known buildings for this time period (Figure 4.I3). The inhabitants already belonged to the sphere of the Naqada culture, which had replaced the earlier Lower Egyptian culture in the region by this time. As for the function of the massive building complex, it has been suggested that it might have played an important role in trade with the Palestinian region, according to fragments of foreign pottery found during the fieldwork. Evidence for administrative activity comes from clay sealings that have also been excavated at this site. The complex probably functioned as an elite residence, with possible links to the larger trade network connecting the Delta and Palestinian regions as well as Upper Egypt. This explanation fits well with the evidence for long-distance trade and the emergence of the administrative system, including evidence for early writing, that has been found at the exceptional tomb $U_{-j}$ situated at Abydos, which probably belonged to an early ruler controlling the northern parts of the country. ${ }^{49}$

However, currently the best-known examples of off1cial structures are two large building complexes of possibly palatial character and enclosed by a perimeter wall that have been excavated at Buto and Hierakonpolis, respectively (see Figures 4.32 and 4.26). Both examples date to the Early Dynastic Period. The internal layout consists of a multitude of connecting rooms and courtyards that are often difficult to assess in terms of their precise use and function. In both cases it is not clear how the building complex relates to the remainder of the settlement. At Hierakonpolis, the presence of clay sealings in one of the rooms indicates that some administrative activity might have taken place there. ${ }^{50}$ Magazine-like rooms probably 
THE ORIGINS O F URB A N S O C I E T Y

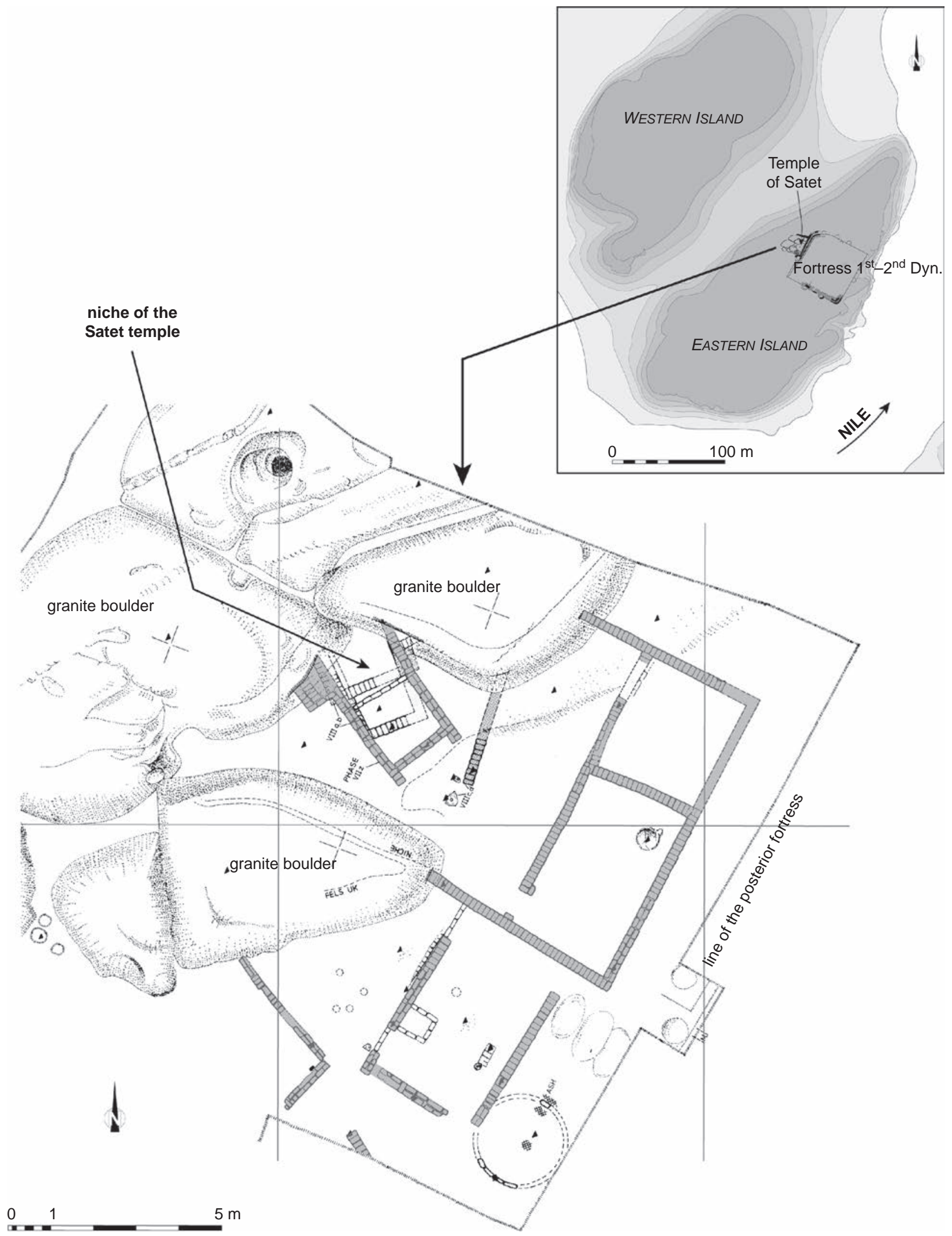

4.II. Temple of Satet during the Early Dynastic Period at Elephantine. By G. Marouard, after G. Dreyer, Elephantine VIII: Der Tempel der Satet, AV 39, I986, I3, Abb. I. 


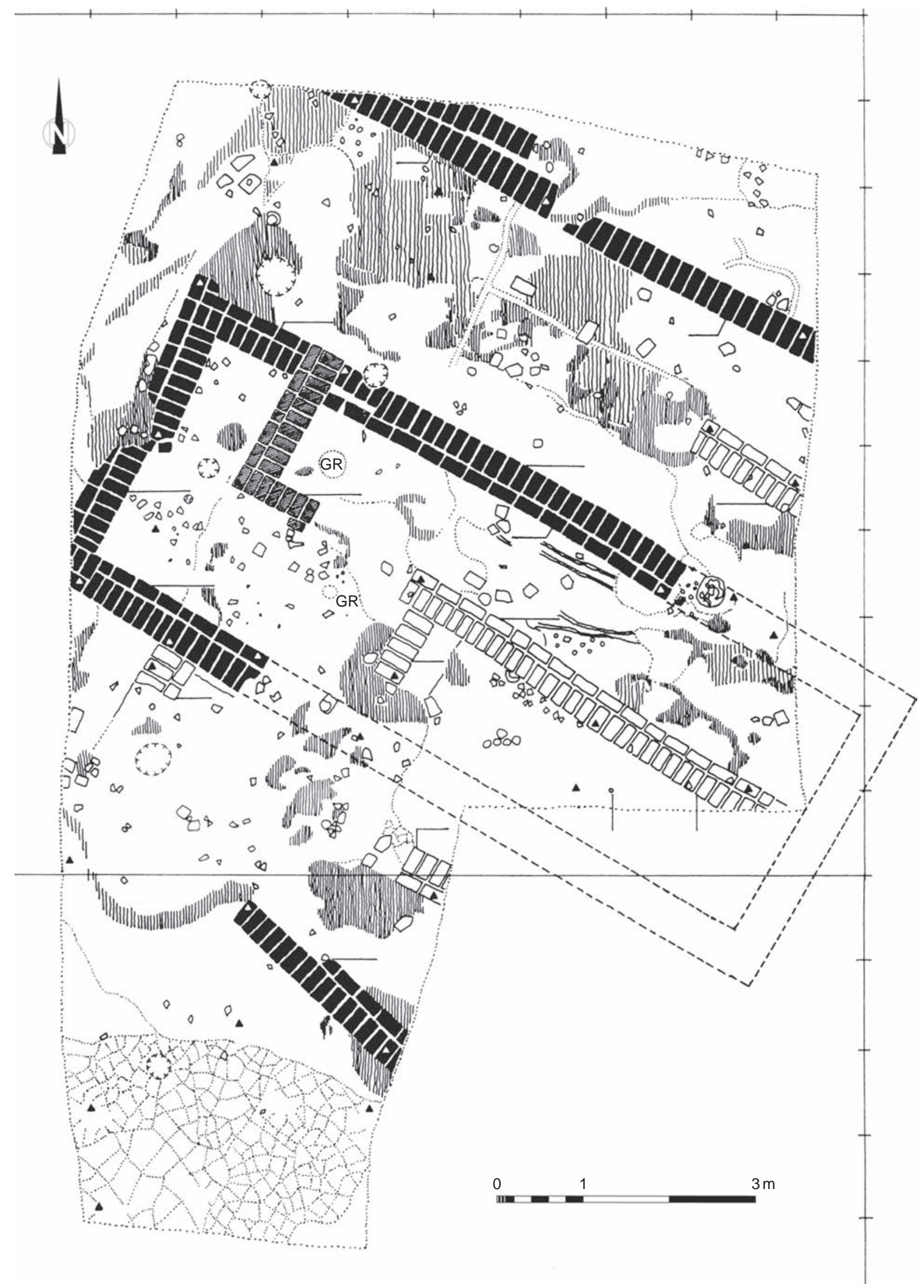

4.I2a. Plan of the early shrine (Dynasty o) at Tell Ibrahim Awad. After D. Eigner, "Tell Ibrahim Awad: Divine Residence from Dynasty o until Dynasty I I," Ägypten und Levante Io (2000), 34, fig. Io. Courtesy of D. Eigner. 


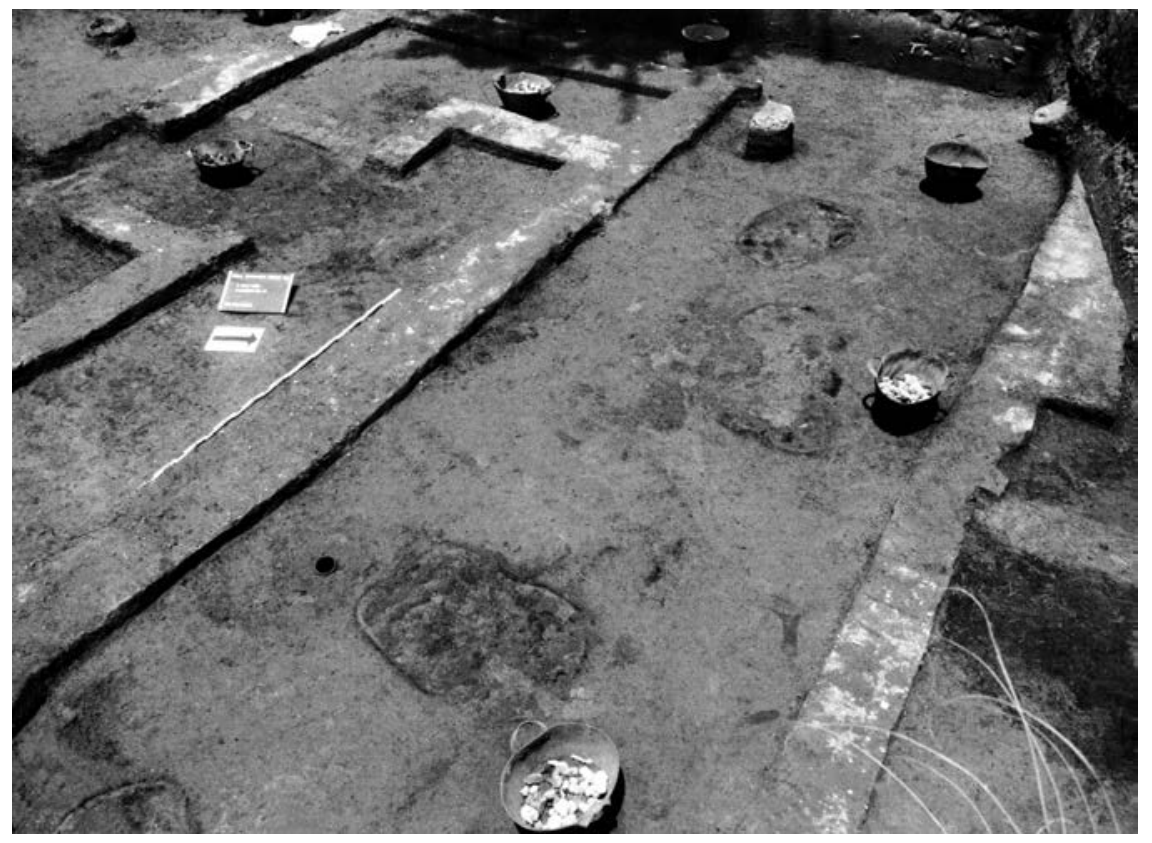

4.I2b. View of the early shrine (Dynasty o) at Tell Ibrahim Awad. After D. Eigner, "Tell Ibrahim Awad: Divine Residence from Dynasty o until Dynasty I I," Ägypten und Levante Io (2000), 3 I, pl. IIIb. Courtesy of D. Eigner.

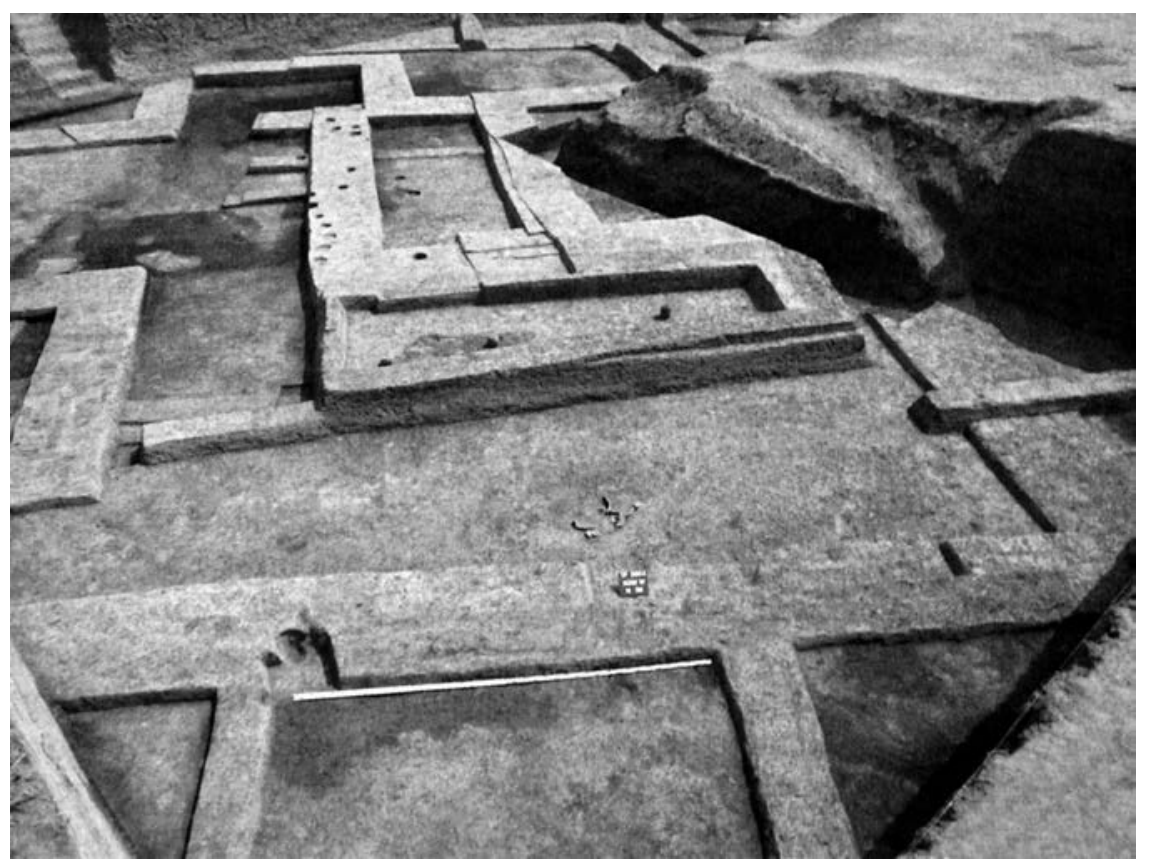

4.I3. View of the Naqada period "residence," Western Kôm at Tell el-Farkha. After K. M. Ciałowicz, "From the Residence to Early Temple: The Case of Tell el-Farkha," in K. Kroeper et al. (eds.), Archaeology of Early Northeastern Africa. In memory of Lech Krzyzaniak, Poznan 2007, 922, fig. 4. Courtesy M. Chłodnicki and K. M. Ciałowicz.

used for large-scale storage were excavated at Buto in one part of the building complex. ${ }^{5 \mathrm{I}}$ Such features suggest that these complexes functioned as a kind of palatial complex for a powerful leader in charge of the town or even on a wider regional level - a kind of early version of the governors' residences known from the Dynastic period. 


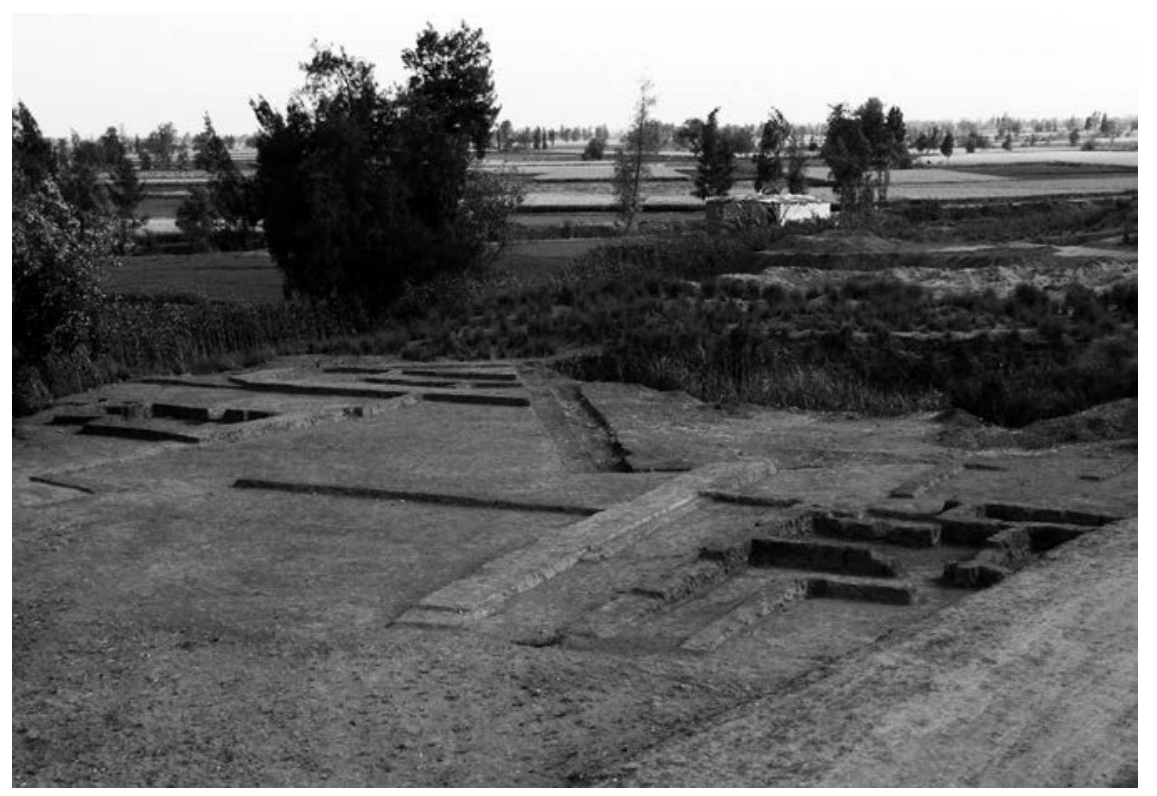

4.I4a. Early Dynastic administrative-residential complex, Western Kôm at Tell el-Farkha. After K. M. Ciałowicz, “The Early Dynastic Administrative-Cultic Centre at Tell el-Farkha," BMSAES I3 (2009), I03, fig. Io. Courtesy M. Chłodnicki and K. M. Ciałowicz.

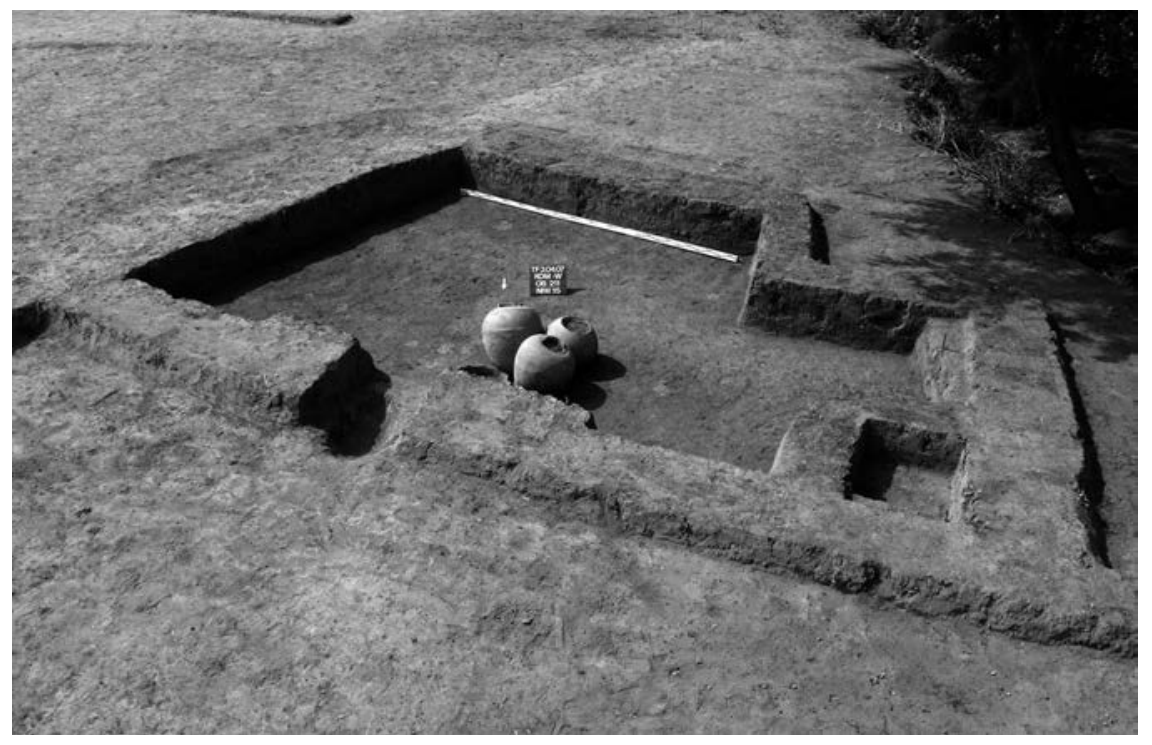

4.I4b. Early Dynastic administrative-residential complex, Western Kôm at Tell el-Farkha. After K. M. Ciałowicz, “The Early Dynastic Administrative-Cultic Centre at Tell el-Farkha,” BMSAES I 3 (2009), Io3, fig. I I. Courtesy M. Chłodnicki and K. M. Ciałowicz.

Another substantial administrative building complex of the Early Dynastic Period (early Dynasty I) has been discovered on the Western Kôm at Tell el-Farkha (Figure 4.I4). ${ }^{52}$ Residential and official areas have been excavated, including two deposits of votive objects that also suggest the presence of shrines within the complex. ${ }^{53}$
The excavations revealed two cult deposits consisting of small votive objects in the form of figurines made of ivory and faience. One of the deposits was found in a small room measuring $3 \mathrm{~m}$ by $3.2 \mathrm{~m}$ - of square layout and built with unusually thick mud-brick walls of I.2 $\mathrm{m}$ - which seems to have functioned as a cult place (Figure 4.I 4 b). It 
was surrounded by further rooms built of thinner walls and showing evidence for domestic use in features such as hearths, storage vessels, and grinding stones that seem to characterize the residential part. The interior of the whole building complex was constructed in the same way as has been observed at the other official structures described previously, where the interior of each large complex consists of numerous interconnecting rooms without any obvious hierarchy, in the agglutinated way typical for this period (Figure 4.I4a). ${ }^{54}$ It seems that the three typical elements (residential, official, and cultic parts) that characterize the residences of local governors and mayors of the later Pharaonic periods are already present here. Excavations at this site are still in progress, and the perimeters of the building have not yet been fully identified.

Another identifying element for official building complexes is the perimeter wall, which physically separated them from the rest of the settlement. The most elaborate enclosure was found at Hierakonpolis, where the gate area was built in a niched pattern that has been called "palace façade" style (Figure 4.26). ${ }^{55}$ This decoration has an intrinsic symbolic meaning closely but not exclusively linked to ancient Egyptian kingship. The remainder of the enclosure was decorated with a small protruding buttresses on the outside, for at least the stretch of wall that was directly linked to the gate (see Figure 4.27). Up to the discovery of this elaborately constructed gateway, all monuments and constructions showing a palacefaçade motif had come from the funerary sphere, such as the exterior decoration of mud-brick mastabas belonging to the highest elite of the time. Such a palace-façade decoration can also be seen on the exterior walls of the large funerary enclosures of the Early Dynastic Period at Abydos, the mastabas at Saqqara and at the later enclosure wall made in stone surrounding the Djoser pyramid complex (Third Dynasty). ${ }^{56}$

As for the precise purpose of this building complex within the town center of Hierakonpolis, the interpretation remains speculative (see full discussion following), but it is clear that the enclosure marked a very specific building area - possibly a type of "palace." At Buto, the enclosure wall is not decorated but also surrounds a building complex of importance and has a kind of monumental entrance gate in its center. There are, in addition, certain elements that were uncovered inside that clearly mark it as a structure with official functions (Figure 4.32). ${ }^{57} \mathrm{~A}$ possible third example of an official building complex was found at the "South Town" at Naqada. Only a part of the perimeter wall has been found, with few remains of mud-brick buildings inside it (see Figure 4.9). It has been suggested that it functioned as an early palace or administrative complex, but there is not enough data to confirm this hypothesis. ${ }^{58}$

These examples show quite clearly that official buildings can be recognized especially by their perimeter walls, while their internal layout is not much different from that of the rest of the settlement. A slightly different situation might be detectable at Tell el-Farkha, where substantial mud-brick walls of I.2 m thickness characterize the main walls and those surrounding one of the votive deposits; these walls seem to be different from the thinner ones in the areas that have been identified as domestic in function (Figure 4.14b). ${ }^{59}$

The perimeter walls may have primarily served the purpose of separating the more "official" building complex from the rest of the settlement, marking its exclusivity. At the same period during which these official structures appear in the archaeological record, the presence of larger town walls can be found too, delineating an increase in complexity within the layout of the earliest towns.

\subsubsection{The evidence for enclosure walls}

The Early Dynastic Period is also the time when the first enclosure walls appear around settlements, functioning as town walls and often fortified; however, the presence of such enclosures also marks fortresses. At the island of Elephantine, a square fortress with a thick mud-brick enclosure wall was erected during the First Dynasty. From the end of the First to the mid-Second Dynasty, additional walls were attached against the south and western sides of the fortress in order to include within a defensive enclosure the entire local settlement that had developed to the south and north of the fortress. ${ }^{60}$ The fortress remained at the heart of the settlement (see Figure 4.15). However, the mud-brick buildings inside it and those on the outside, which belong to the wider settlement at Elephantine, indicate no visible distinction between the two areas with regard to size, construction technique, thickness of walls, and layout of buildings (Figure 4.I5). ${ }^{\text {I }}$ They seem to be identical and consist of smaller rooms arranged around larger courtyards, with evidence for domestic activities such as storage (small round silos), fireplaces, and deposits from settlement waste. ${ }^{62}$ This marked lack of differences in the buildings within and outside of the fortress shows clearly that apart from the fortress walls themselves, no larger planning was 


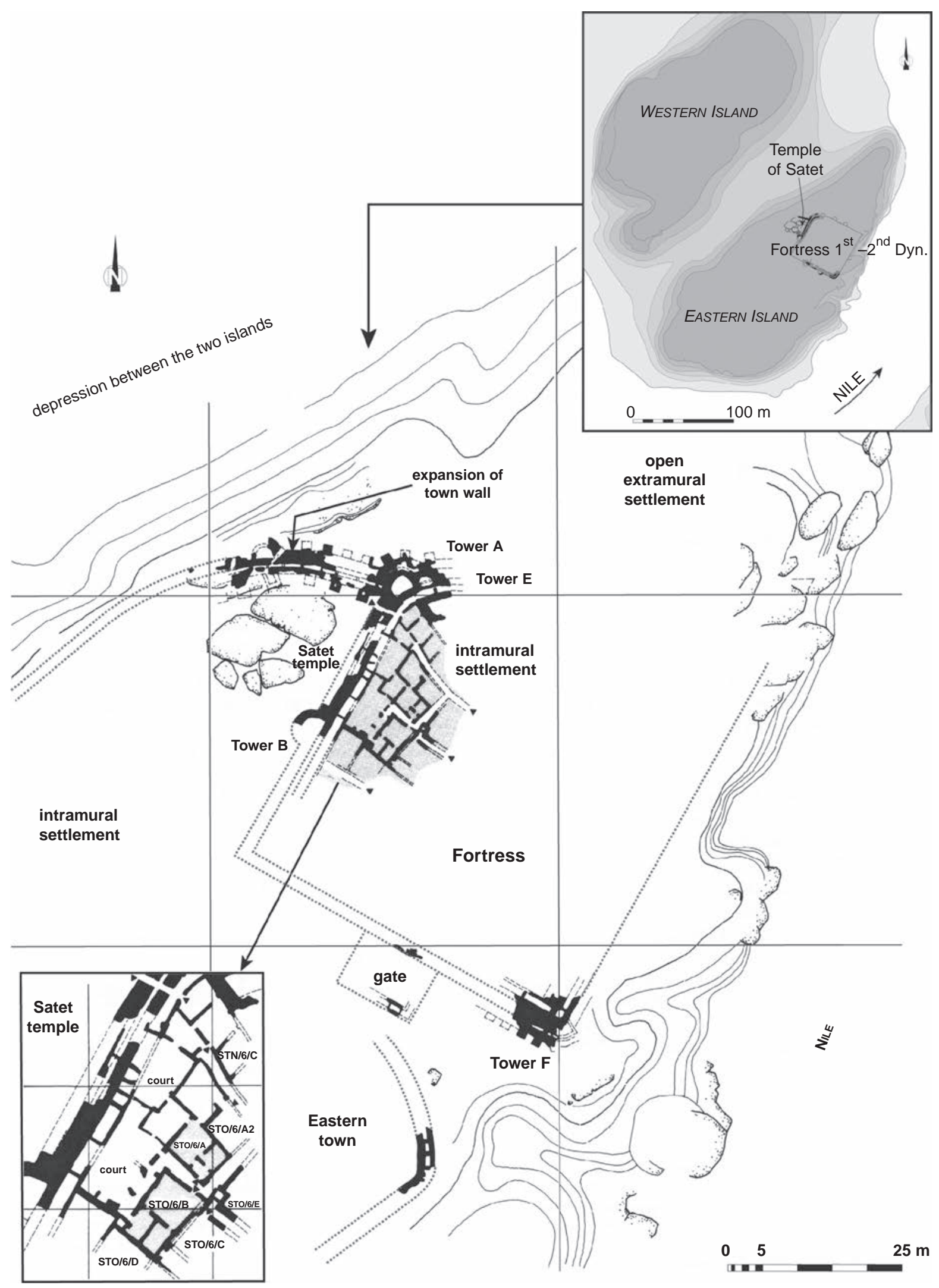

4.I5. Early Dynastic fortress and settlement (second half of Ist Dynasty-early 2nd Dynasty) at Elephantine. By G. Marouard, after W. Kaiser et al., "Stadt und Tempel von Elephantine, I9./20. Grabungsbericht," MDAIK 49 (I993), I37, Abb. I. 
conducted for the organization of the interior. And probably the same community occupied the inside of the fortress as well as the outer settlement at that time. The fortress is mainly characterized by its massive enclosure wall, but the internal structures do not follow any specific layout, nor does there seem to be any hierarchies among them that can be recognized from the architecture alone; it is also difficult to distinguish individual buildings, because they were constructed in the same agglutinated fashion that is typical for Early Dynastic settlement remains in general. This design stands in sharp contrast to that of the later fortresses in Lower Nubia, which were built during the Middle Kingdom. ${ }^{63}$ All of those fortified structures have a very specific and strictly orthogonal layout and organization in the interior - quite different from domestic quarters encountered in most contemporary settlements at the time (with the exception of stateplanned towns) and constituting evidence for large-scale planning. ${ }^{64}$

The fortress of Elephantine, dating to the First Dynasty, has one of the earliest examples of a large, fortified, mud-brick enclosure wall. During the Second Dynasty, additional wall segments of similar characteristics were added to enclose the growing settlement on the island (Figure 4.I5). These massive fortifications are certainly linked to the island location of this site at the southern border of Egypt, but they are also evidence for the existence of and the ability to build mud-brick walls of very large scale that early - at the end of the Predynastic/Early Dynastic periods. The walls stand in sharp contrast to the thin ones of domestic dwellings that were typical at that time.

Tell es-Sakan, which is situated about $5 \mathrm{~km}$ south of Gaza in southern Palestine (Figure 4.I6), provides new evidence for a sequence of fortified mud-brick enclosure walls; this is considered one of the earliest Egyptian examples known so far. ${ }^{65}$ The site was partially excavated in 1998 as part of a rescue excavation during modern construction work and yielded evidence for various phases of settlement dating to the Early Bronze Age. The Egyptian occupation encompasses phases A-9 up to A-6 (Figure 4.I7). The first phase of settlement was well preserved and did not show any signs for the presence of a defensive wall. However, from phase A-7 onward, three successive phases of enclosure walls ( $\mathrm{A}_{\mathrm{I}}, \mathrm{A} 2$, and $\mathrm{B}$ ) were discovered (Figure 4.7). The oldest one, enclosure AI, was $\mathrm{I} .5 \mathrm{~m}$ wide and still preserved to a height of about I. 5 m. ${ }^{66}$ In a second phase, enclosure A2 was added against its interior - probably in order to reinforce it.
The total width of both walls reached $3.55 \mathrm{~m}$, and three consecutive floor levels can be associated with it. In the next phase of occupation, both parts of Wall A were dismantled and a new, thicker enclosure wall, Wall B, was built above it, following the same orientation. Wall B had a thickness of $3.80 \mathrm{~m}$ and was preserved up to $\mathrm{I} .8 \mathrm{~m}$ in height in the cuts of the archaeological trenches. ${ }^{67}$ Additional evidence for its defensive function comes from a large glacis, also made of mud brick, added against its exterior; it measured $5 \mathrm{~m}$ in width and protected the base of the enclosure wall (Figure 4.I7).

Along the interior of this enclosure, thin mud-brick walls forming rectangular buildings and several round silos were uncovered, pointing to a domestic character, without any evidence for a hierarchy among the structures. This design is very similar to the evidence from Egypt of the same time period. Even the organization and layout of the buildings is comparable to that found in Egypt proper, and the fully Egyptian character of this settlement has also been confirmed by the presence of purely Egyptian objects, especially pottery. ${ }^{68}$ According to the pottery evidence, the various building phases of this enclosure and settlement date mainly from $3300 \mathrm{BCE}$ to about $3000 \mathrm{BCE}$, encompassing most of Dynasty o (= Naqada IIIB-C). ${ }^{69}$ The sequence of enclosure walls can therefore be considered the earliestknown Egyptian example of defensive character; the only other site that also shows clear evidence for successive fortified enclosure walls is Elephantine, which dates from the First Dynasty onward. Here the walls were continually enlarged to enclose the growing settlement on the eastern island. Interestingly, such mud-brick enclosure walls are rare in Palestine, and there are only two examples that are roughly contemporary to Tell esSakan: one was found at Megiddo and another at Tel Shalem, both dating also to the end of the Early Bronze Age IB period and located further north, though these examples were not enclosing Egyptian settlements. ${ }^{70}$ Tell es-Sakan is currently the only fortified settlement in the southwestern part of Palestine and probably functioned as an Egyptian colony securing important trade networks. For Egypt proper, it is difficult to assess whether the appearance of large, fortified enclosure walls can be linked to any specific region, but they are evidently present in the border regions.

The other main function of enclosure walls is as perimeter walls around specific building areas that are not defensive in nature but should be understood as delineating an exclusive zone or building complex of 


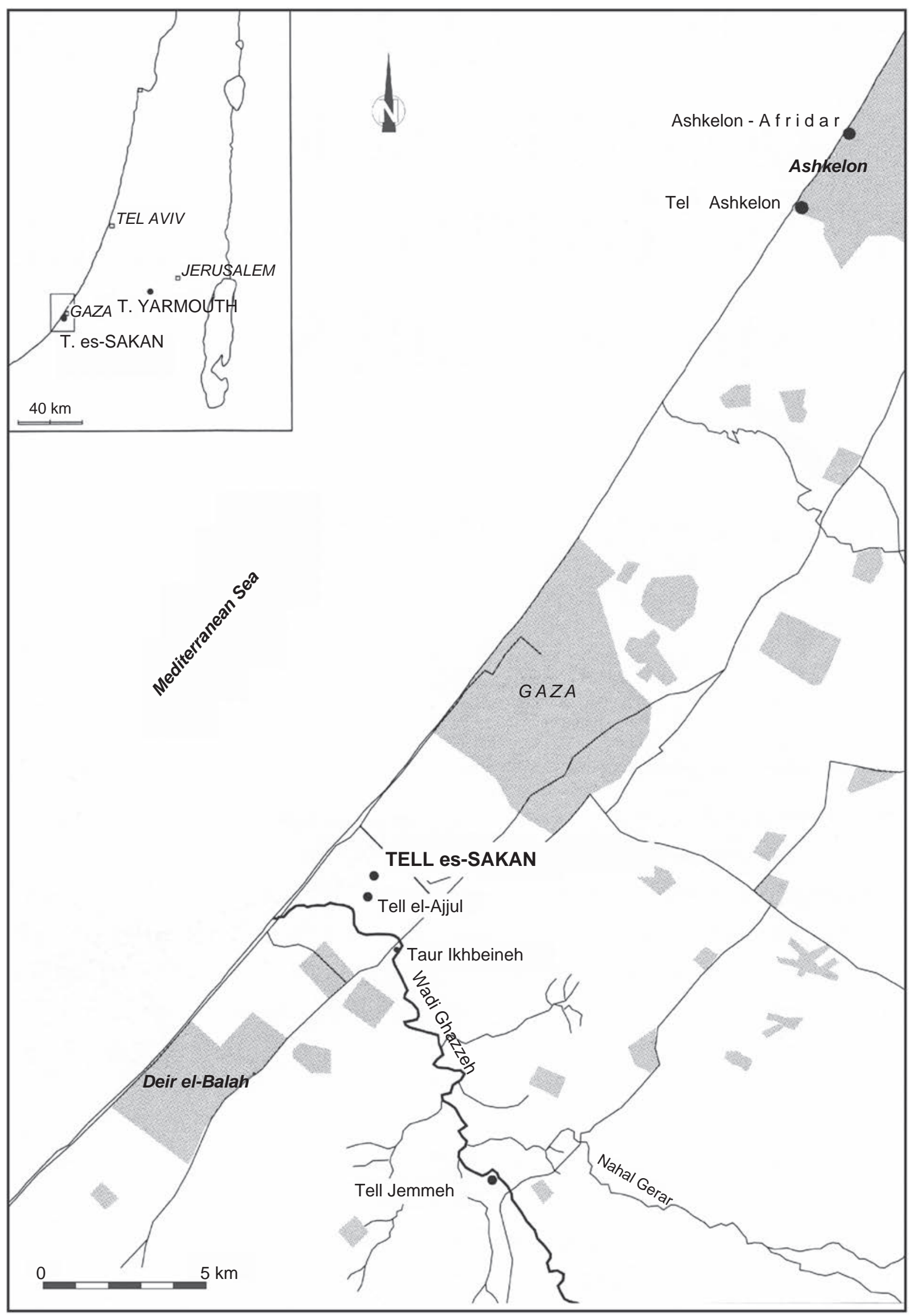

4.I6. Position of Tell es-Sakan in the Gaza region. After P. de Miroschedji et al., "Les fouilles de Tell es-Sakan (Gaza): Nouvelles données sur les contacts Égypto-Cananéens aux IVe-IIIe millénaires,” Paléorient 27 (200I), 76, fig. 7I. Courtesy of P. de Miroschedji. 
a)
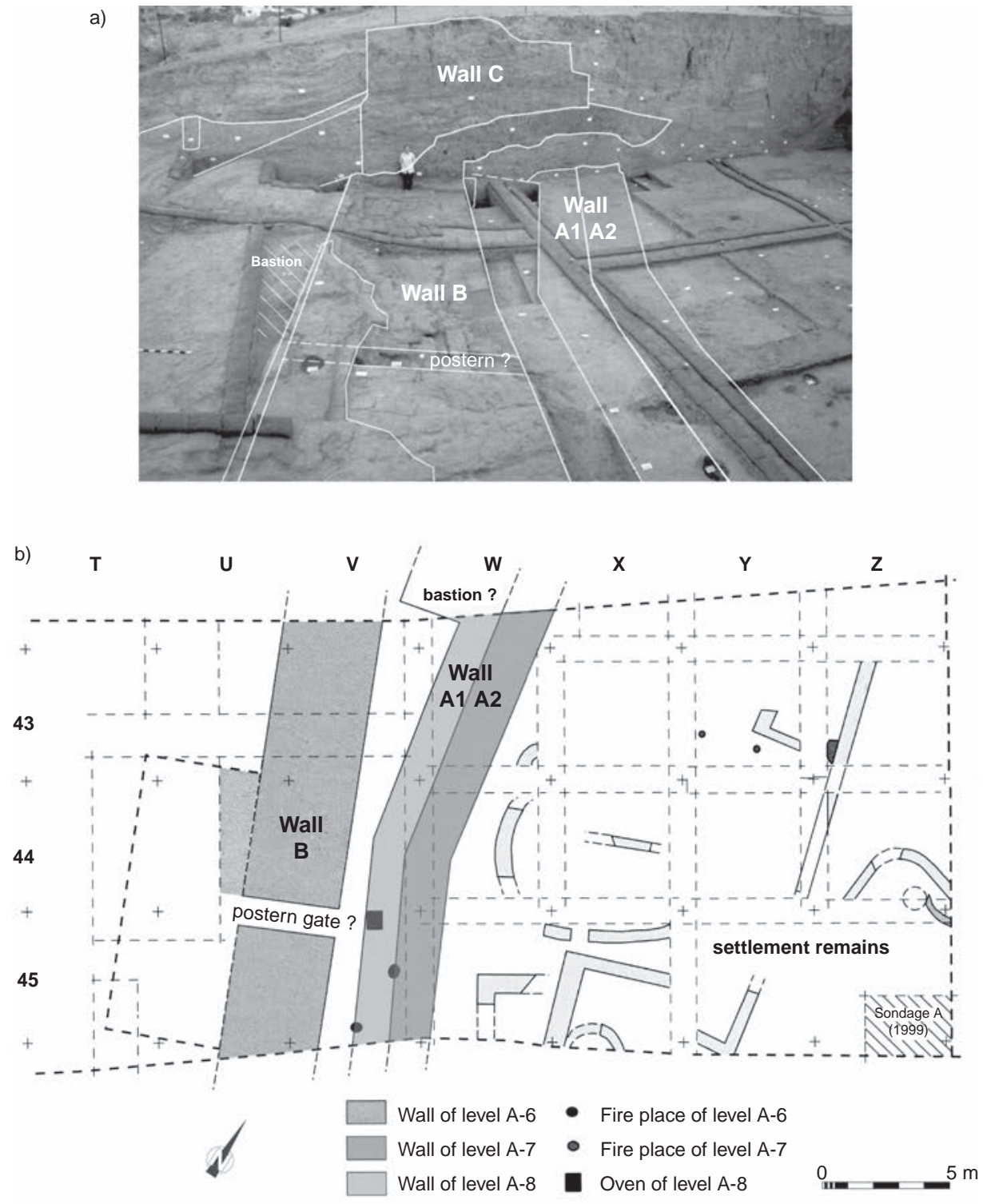

c)

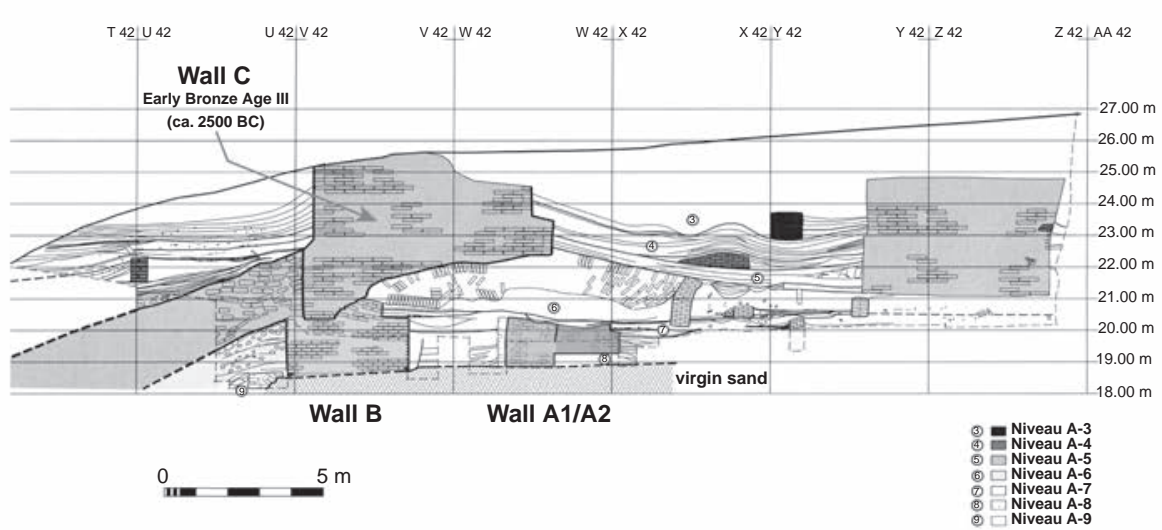

4.I7. View, plan, and northern profile of the different phases of enclosure walls, Area A at Tell es-Sakan. By G. Marouard, after P. de Miroschedji et al., "Les fouilles de Tell es-Sakan (Gaza): Nouvelles données sur les contacts Égypto-Cananéens aux IVe-IIIe millénaires," Paléorient 27 (2001), 82, figs. 86, 88, and 89. Courtesy of P. de Miroschedji. 
official character (see previous discussion). From the archaeological evidence, it can be deduced that a wall with a thickness of two meters or more is most likely an enclosure wall and could have functioned either as a settlement enclosure or as marking an important building complex. The known examples range from relatively simple perimeter-style walls to decorated enclosures such as the palace-façade gate and wall at Hierakonpolis. The enormous mud-brick walls that form the royal funerary enclosures at Abydos can be considered a third kind of enclosure wall - probably with a more symbolic or ritual function. There is currently no evidence for any early temple enclosure wall predating the Old Kingdom. The so-called fort structure at Hierakonpolis, which has been associated with the Second Dynasty ruler Khasekhemwy is another puzzling building marked by a massive enclosure wall and fortified entrance, but its precise function remains speculative. ${ }^{7 \mathrm{I}}$ It resembles most closely the funerary enclosures at Abydos, although it probably did not share their function as a funerary monument. ${ }^{72}$

These various characteristics discernible from the earliest settlements provide a useful framework for the investigation of two sites for which there is a considerable amount of information available from archaeological fieldwork. The best-known settlement encompassing the entire evolution from the Predynastic to the Early Dynastic Period is Hierakonpolis. Together with the settlement at Buto and the new evidence there, these sites are currently the most complete ones that have been studied thus far. They also provide comprehensive evidence for the emergence of early urban centers in Egypt and the beginnings of urban society.

\subsection{THE CASE OF HIERAKONPOLIS}

The ancient city of Nekhen has been regarded as one of the key Upper Egyptian sites that can be closely linked to the emergence of the ancient Egyptian state and the formation of early kingship. ${ }^{73}$ It has also been interpreted as the seat of power for early rulers exercising power over a larger region or "proto-kingdom," until it became integrated into the administrative system of provinces during the early Old Kingdom as the capital of the third Upper Egyptian nome. ${ }^{74}$ The evolution of Nekhen during this early period of ancient Egyptian history has been investigated through extensive fieldwork carried out at the site and is still in progress. ${ }^{75}$
Nekhen's importance was recognized during the first excavations at the site more than Ioo years ago, which were marked by the discovery of historically important objects such as the Scorpion mace head and, more significantly, the Narmer palette at the "Main Deposit" within the temple. ${ }^{76}$ Scholars have credited King Narmer for unifying the country, according to the depictions on the palette, and have assumed that he had a residence or at least a cult at ancient Nekhen. ${ }^{77}$ The rich archaeological data that has emerged, especially from later fieldwork, confirms that Nekhen had been an important urban center early on, possibly as the capital of a proto-kingdom that played an important role in the formative period of the state. ${ }^{78}$

\subsection{The Predynastic settlement at Hierakonpolis}

The larger region of Hierakonpolis is one of the rare archaeological areas where the development from the Predynastic to the Early Dynastic period can be followed without a break, thus providing an important case study of the emergence of an early urban center and for what factors might have been decisive in this evolution. ${ }^{79}$ It is important to include here a brief overview of the earlier Predynastic settlement, which covers the Naqada I to III periods (3800-3IOO BCE), in order to put the later Pharaonic period townsite within the context of this wider development. Large-scale surveys including a drill-core survey and more-detailed excavations in selected areas, which have been conducted since the late I960s, have revealed a considerable amount of data in order to evaluate the characteristics of the early settlement. ${ }^{80}$ Also, and very much an exception for such research, a more interdisciplinary approach was taken at the site by the beginning of the I980s. ${ }^{81}$

As the situation stands now, it is possible to divide the archaeological area into various parts according to the types of installations, such as cemeteries versus settlements, and also according to the environmental settings, such as desert versus floodplain. The current concession encompasses an area of I $44 \mathrm{~km}^{2}$ and includes not only very different habitats but also different types of sites with archaeological remains, providing insights into a variety of human activities (Figure 4.I8). ${ }^{82}$ Archaeological ground surveys and excavations in the desert area at Hierakonpolis have convincingly shown the emergence of a large Predynastic settlement that includes ample evidence for social stratification and craft specialization as well as a population concentration estimated at 


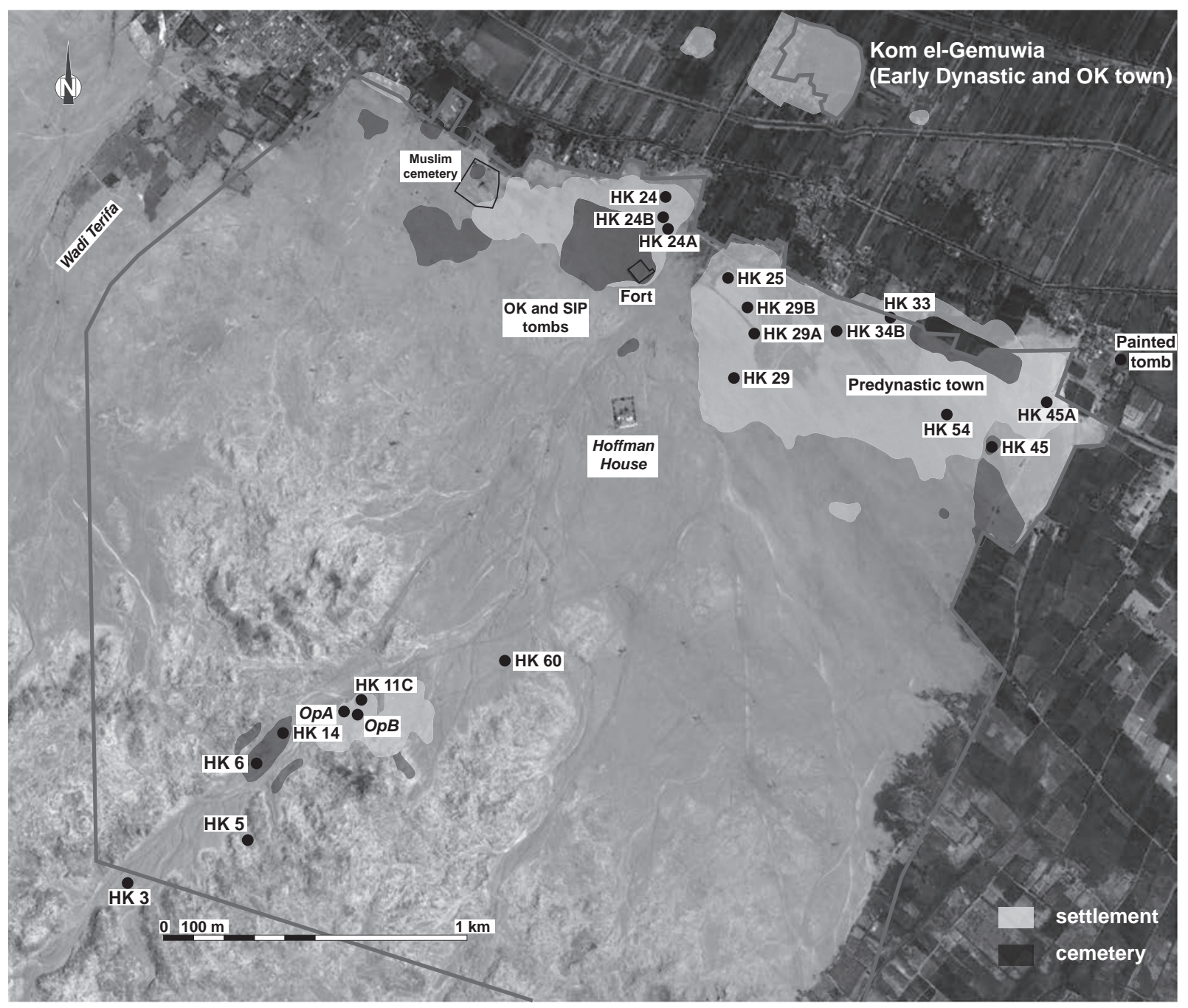

4.I8. Satellite view (2009) of the archaeological area at Hierakonpolis. By G. Marouard, using Google Earth ${ }^{\mathrm{TM}}$, image $\mathrm{C}^{20 \mathrm{I} 4}$ DigitalGlobe, and after M. Hoffman, et al., "A Model of Urban Development for the Hierakonpolis Region from Predynastic through Old Kingdom Times,” JARCE 23 (1986), I79, fig. I; R. Friedman, Nekhen News I4 (2002), 2.

between 5,000 and I0,000 people settling in this area of 32 ha to 37 ha by the Naqada IC-IIA period. ${ }^{83}$ In his groundbreaking study of the urban development at Hierakonpolis, Michael Hoffman was able to discern four major stages that constitute the principal phases in the evolution of settlements, starting with Phase I (Naqada IA-B, ca. 4000-3800/3700 BCE), marked by the first settlers arriving probably from the north and establishing themselves there. The region had the advantage of easily accessible fertile soil and water resources in form, respectively, of Wadi Abu Suffian and a Nile channel running close to the desert edge, and also provided access to raw materials (Figure 4.I9). No architectural remains for this earliest phase have been recovered, but it has been proposed that although the origins of Hierakonpolis might have been in the form of seasonal campsites, the local environment favored the gradual evolution to long-term settlement. ${ }^{84}$

Hoffman determined the second stage of development (Phase II, or the Early Predynastic period) as a period of growth dating between $3800 / 3700$ and $3500 / 3400$ BCE (Naqada IC-IIA/B) (Figure 4.I9). ${ }^{85}$ This unusually large area, covering more than 36 ha, includes various habitation and settlement types, which range from seminomadic campsites and isolated clusters of buildings such as hamlets and farmsteads to larger towns. ${ }^{86}$ Of the two largest settlements, one is located close to the edge of the current floodplain, ${ }^{87}$ probably originally spreading 

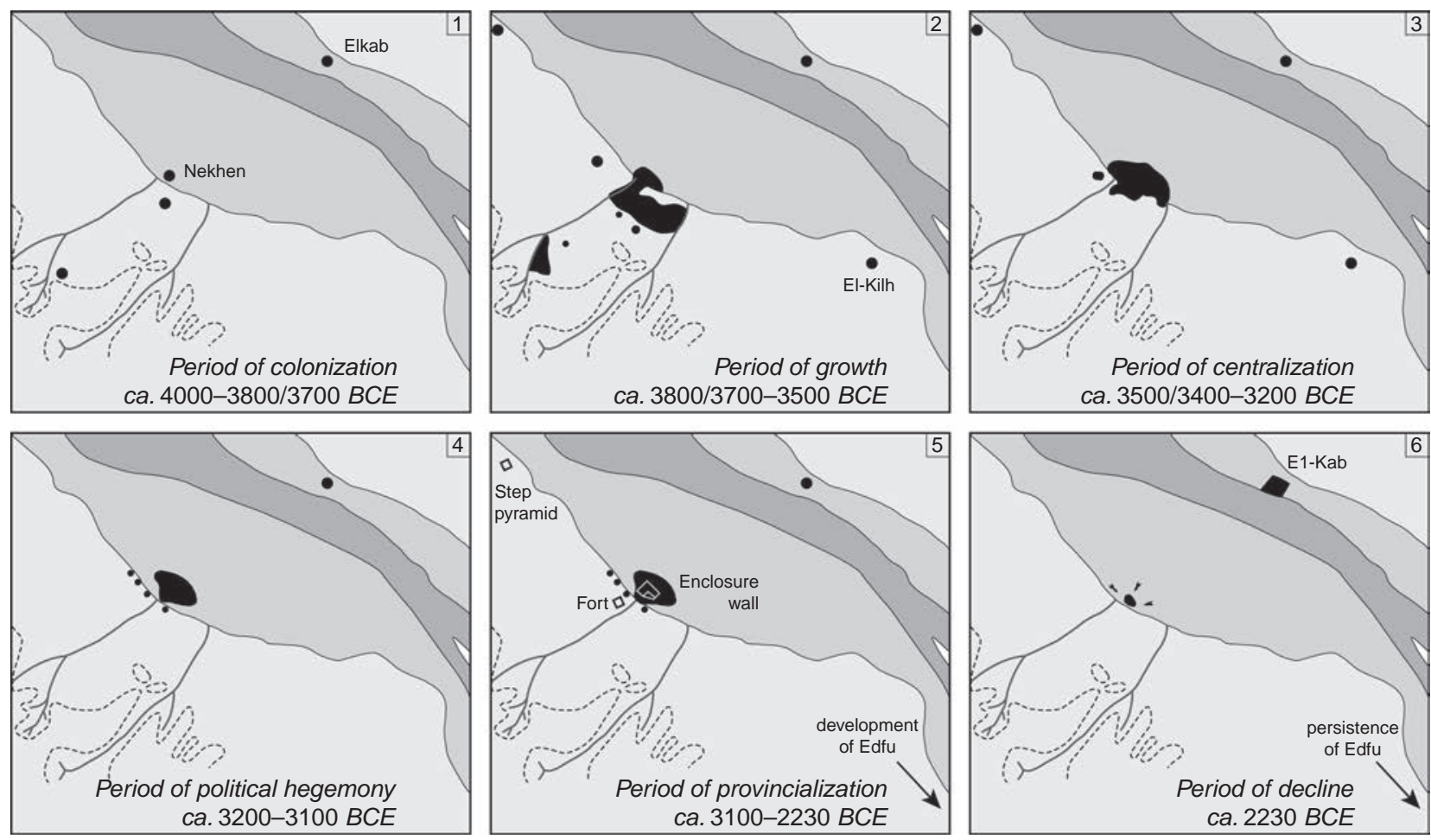

4.I9. Development of the Predynastic-Old Kingdom settlement at Hierakonpolis. By G. Marouard, after M. A. Hoffman, H. A. Hamroush, and R. O. Allen, "A Model of Urban Development for the Hierakonpolis Region from Predynastic through Old Kingdom Times," JARCE 23 (I986), I82, fig. 3.

further toward the east but now lying underneath a cover of thick layers of Nile silt and wadi deposits. ${ }^{88}$ The second-largest site including evidence for settlement activity is situated along the Wadi Abu Suffian. ${ }^{89}$ This latter site has been characterized as a "cluster of multifunctional components including trash mounds, kilns, and habitation areas. ${ }^{\circ \circ}$ Furthermore, numerous production sites for pottery and food (bread and beer) have been excavated that have important implications for the organization and functioning of these settlements (see following discussion).

Phase III of the urban development encompasses the Naqada IIB-D periods (ca. 3500/400-3200 BCE) and has been characterized as a time of "centralization" (Figure 4.19). ${ }^{91}$ The widespread character of the settlement along the desert edge shrinks to a smaller, more nucleated town of $5^{-7}$ ha in size clustering near the border with the floodplain. The full extent and related evolution of the settlement reaching into the floodplain is still largely unknown, but the drill-core survey and excavation at the later settlement situated at Kôm el-Gemuwia ${ }^{92}$ clearly show the presence of human settlement activity there dating back as far as the transitional period between the end of Naqada I and the early Naqada II period. ${ }^{93}$ Main factors influencing this shift from the low desert zone into the Nile Valley are related to changing environmental conditions such as drier conditions in the desert, lower Nile floods, and probably overexploitation of natural resources such as wood for industrial fires for pottery and food production. At the same time, an increase in social complexity can be witnessed - for example, by the elaborate Tomb ıoo, which was built with lined mud-brick walls and had painted decoration on one of its walls. ${ }^{94}$ Further contributing factors - less visible from the archaeological data - might have been of political or strategic nature. The town became more nucleated but did not yet have an enclosure wall.

From the Naqada III period onward (ca. 3200-3 100 BCE $=$ Phase IV), ancient Nekhen developed into a major city in the form of a compact tell site within the floodplain at Kôm el-Gemuwia, while the desert zones were gradually being abandoned for settlement, although still being used for cemeteries (Figure 4.19). ${ }^{95}$ By the Early Dynastic Period into the early Old Kingdom (ca. 3 IOO-2700 BCE), no more settlement could be found in the desert, and all of the population concentrated inside a 
walled city in the floodplain that is located about $360 \mathrm{~m}$ from the desert edge (Figure 4.I8). It currently lies at $2 \mathrm{~km}$ west of the Nile, but there might have been a Nile branch or the Nile itself that once flowed much closer to the town in ancient times. A recent drill core that was taken west of the Pharaonic townsite of Nekhen has provided some evidence for a Nile channel running west of the ancient town during the early Predynastic Period that was silted up already by the Early Dynastic Period, when this channel was migrating eastward. ${ }^{96}$ The width of the fertile valley in this region lies at around $4 \mathrm{~km}$, making it one of the larger valley stretches in the south. From the votive objects and a palace-like building complex (see details following), it is possible to deduce the continued importance of the city for early rulers of the First and Second Dynasties. Especially prominent names associated with the city of Nekhen are Narmer, Scorpion, and Khasekhemwy.

It has been suggested that the site declined considerably during the later Old Kingdom, with activity concentrating around the temple site. This last phase in the suggested development - termed Phase V, Provincialization, ca. $3 \mathrm{IOO}$ to 2230 BCE (Early Dynastic-Old Kingdom, Dynasties I-6) by Hoffman - covers about 800 years, which can be divided into various subphases, the Early Dynastic period (Dynasties I and 2) being one of them (Figure 4.I9). From the archaeological reports of the excavations at the site, it is clear that extensive sebakh digging had removed all the upper layers of the tell site, leaving intact only remains from the Old Kingdom and earlier. It is therefore very difficult to make any firm conclusions about the state of the settlement during the final phase in the development of settlement at Hierakonpolis as established by Hoffman. Archaeological evidence dating to the postFourth Dynasty era is severely disturbed and in many areas completely removed. ${ }^{97}$ In the temple, several objects of the Sixth Dynasty were found in pits of buried votive objects..$^{98}$ According to the current state of research, it is not possible to draw any more conclusions about the development of Nekhen after the Fourth Dynasty (ca. 2500 BCE), and Hoffman's suggestion of a decline remains questionable.

The gradual shift toward the floodplain that led to the rise of a more compacted settlement is the result of one of the later stages of development within a very dynamic region but is also part of a much larger phenomenon that has been observed elsewhere - for example, at the site of Naqada further north, which seems to mirror the situation at Hierakonpolis. ${ }^{99}$ From at least the Third Dynasty onward, ancient Nekhen, the city of the Falcon god Horus, functioned as the capital of the third Upper Egyptian nome. Across the river lies its twin city, Elkab, ancient Nekheb (Figure 4.I), an early urban center of comparable importance, but one where the archaeological remains have been preserved rather poorly. ${ }^{\text {IOO }}$ Satellite images of this part of the Nile Valley show that Hierakonpolis and Elkab are lying exactly opposite each other, probably once adding much control and interaction to river traffic. Evidence for a gradual shift of the Nile eastward can be seen at Elkab from the erosion of parts of the remarkable Late Period enclosure wall still surrounding much of the ancient city and functioning today as a visible landmark.

After having outlined the main phases of development at Hierakonpolis, it is important to investigate some of these phases in more depth in order to establish the various characteristics that define the emergence of early urban society in Upper Egypt. As mentioned previously, Hierakonpolis is one of the rare sites currently published that can be traced back to the early Predynastic period, which helps to establish the origins of numerous components that become typical for later urban centers.

4.3.1.1 The wadi sites of the early Predynastic Period (Naqada I-IIA/B period, ca. 3800/3700-3500/3400 BCE)

The identified sites of settlement activity fall into two main zones: one located along the Wadi Abu Suffian and the other along the flat desert edge close to the floodplain, with possible outliers reaching into the floodplain itself (see Figure 4.I9). This phase of development shows the first signs of large-scale craft specialization in both zones.

At locality $\mathrm{HK}$ I IC, a large, industrial-scale pottery workshop with attached brewery was discovered and excavated recently (Figure 4.20). ${ }^{\text {IOI }}$ The wadi environment during the early Predynastic Period supported a vegetation of tamarisk and acacia trees, providing fuel and also allowing for the existence of seasonal herding. Apart from these production and habitation sites, several smaller outliers of human settlement activity have been noted in the surrounding area along the wadi - such as the round stone huts at $\mathrm{HK}_{3}$ and possibly remains of a small homestead at HK 5 (Figure 4.I8). Evidence for trash disposal from a community living in this area was found at $\mathrm{HK} 60 .{ }^{\text {IO2 }}$ Hoffman suggested that these installations and settlements were linked to the exploitation of seasonal pasturages of the wadi zone. ${ }^{\text {IO3 }}$ One further aspect playing an important role that might actually challenge 

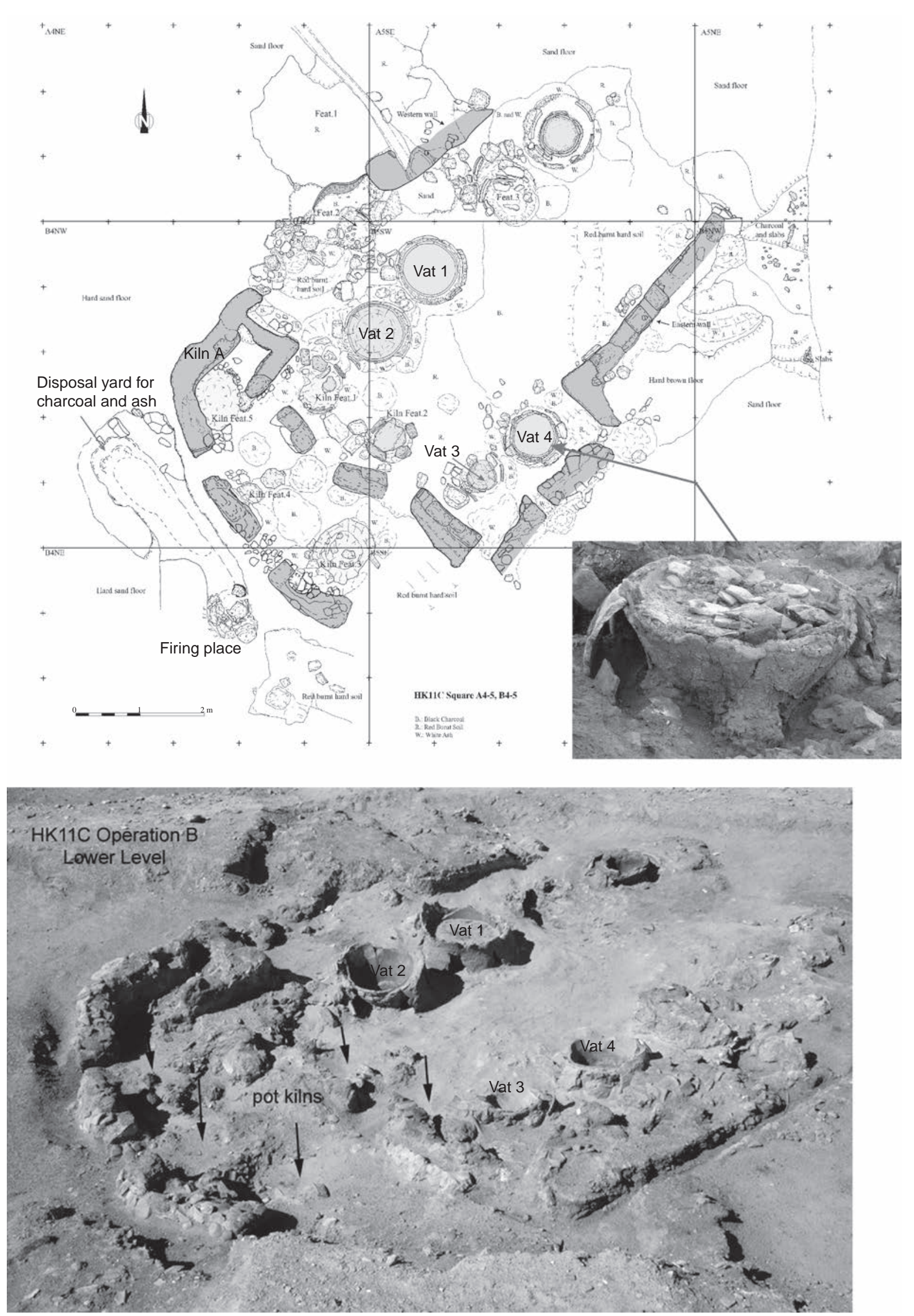

4.20. Brewing facility and pottery kilns at $\mathrm{HK}$ i IC - Square B5 (Naqada IC and IIB period) at Hierakonpolis. Plan by M. Baba, provided courtesy of the Hierakonpolis Expedition. 
some of these identifications as to the nature and role of settlement here is the presence at HK 6 of a large and important elite cemetery whose full significance has only recently been better understood. ${ }^{\text {I04 }}$ This was a place where early chiefs or local rulers were buried, and the site remained a place of veneration for generations to come. ${ }^{\text {IOS }}$ From the current archaeological evidence it is clear that much of the settlement activity was closely related to the cemeteries at the wadi, and specifically the exceptional elite cemetery at HK 6 (Figure 4.I 8). ${ }^{\text {IO6 }}$ This connection evokes the possibility that the production facilities were exclusively supplying the cemetery with goods related to a kind of mortuary cult and operated only on a seasonal basis.

One additional observation that deserves attention on a more general level is the fact that pottery production sites often also included food-producing facilities for example, for beer brewing, which can be identified from remains of large brewing vats on the ground. This is not a phenomenon restricted to the installations discovered along the wadi, because brewing facilities have also been found at other locations in Hierakonpolis. Traces of brewing activity have been noted at other kiln sites: one is the large production complex encompassing localities HK $24 \mathrm{~A}-\mathrm{B}$ and $25 \mathrm{D}$, and another concerns a house and workshop area at HK 29 (Figures 4.I 8 and 4.2I). ${ }^{\text {IO7 }}$

These discoveries certainly show the existence of specialized production sites, which seem to be present within the wider settlement zone but are also found close to the elite cemetery in the wadi area. There does not appear to be a noticeable difference in size or layout of these production areas, whether they were supplying the settlement or the cemetery, except for the fact that the production facility linked to the cemetery functioned on a more intermittent basis. It is possible to note an intrinsic connection between brewery and pottery production, possibly related to practical concerns such as the manufacturing of vessels, which were then filled with beer. This interpretation seems to fit the evidence from the brewery installations at the settlement, but new evidence from $\mathrm{HK}$ I IC shows that although the production of pottery and beer occurred in the same area, the vessels there were not used as receptacles for the beer but instead were items produced exclusively as burial goods. ${ }^{\text {IO8 }}$ It is therefore plausible that production facilities of different kinds of goods were grouped together according to more practical considerations, such as having ovens in the same area, which made it easier for the transportation of firewood or the common use of ovens for different types of production.

$$
\begin{aligned}
& \text { 4.3.1.2 The low-desert settlement near the floodplain } \\
& \text { of the early Predynastic Period (Naqada } I C-I I A / B \text {, } \\
& \text { ca. } 3800 / 700-3500 / 400 \text { BCE) }
\end{aligned}
$$

The largest Predynastic settlement cluster extended into the low desert zone near the floodplain (Figure 4.I9). Today the whole area is characterized by heaps of pottery sherds and holes in the sand, giving it the appearance of a severely eroded and disturbed site. ${ }^{\text {I09 }}$ Nevertheless, the results from surveys as well as excavations in selected areas provide a glimpse of the architectural features and general layout of this settlement and also give an insight into its overall organization. ${ }^{\text {IO }}$ There is evidence for production areas, a religious center, domestic areas, and various other special-purpose installations such as the buildings at the so-called stone mounds. ${ }^{\text {I I }}$

To the east of the Second Dynasty mud-brick "fort" of Khasekhemwy, evidence for a large-scale production area belonging to the early Predynastic town has been identified (Figure 4.I8). It consists of several components: HK 24 A and B were breweries, HK $25 \mathrm{D}$ a breadmaking facility with ovens, and probably all of these localities are outliers of $\mathrm{HK} 24$, an area characterized by the dense accumulation of pottery sherds stemming from a workshop. The close link between these installations can be explained by the fact that evidence for bread making and beer brewing - activities surrounding the two staples of the ancient Egyptian diet - can be found together because bread was needed for making beer. ${ }^{\text {I } 2}$ The proximity of these two facilities to the pottery workshop is probably also linked to practical concerns as, suggested previously for similar installations found along Wadi Abu Suffian.

Apart from the fact that it is possible to see a distinct internal organization within this large settlement according to different settlement quarters, the inhabitants working at this production site situated along the northern limit of the town were probably full-time specialists who received support from other residents of the settlement. Fuel and grain were needed in large quantities for this kind of food and pottery production on an industrial scale, which might have necessitated and encouraged a certain division of labor. The archaeological remains of the installations also provide first evidence for the emergence of the redistributive system, with bread and beer as staple goods playing an important 


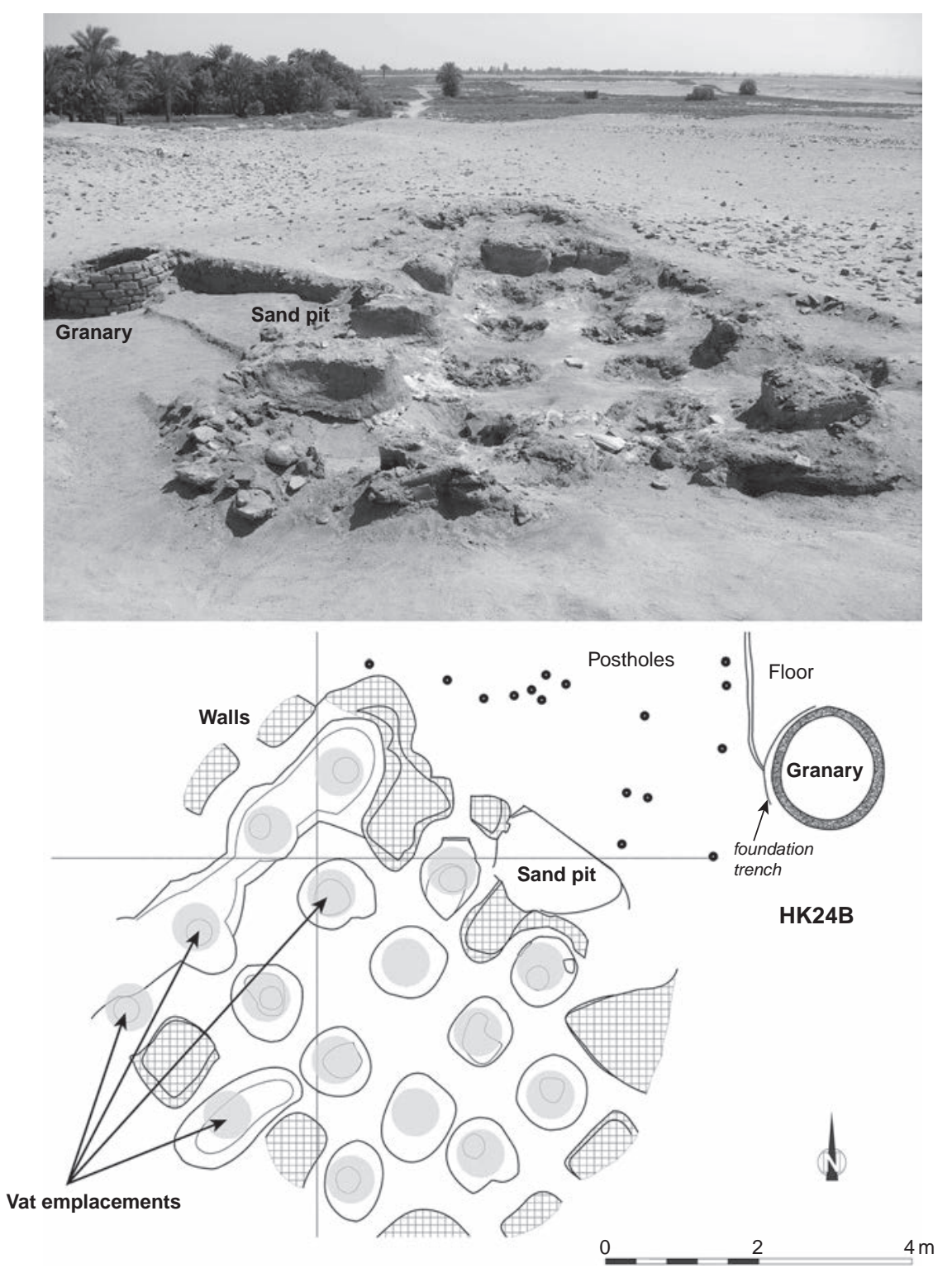

4.2I. Food production installations at HK $24 \mathrm{~B}$ (mid-Naqada I period) at Hierakonpolis. Photo by N. Shirai, and plan by I. Takamiya and N. Shirai, provided courtesy of the Hierakonpolis Expedition.

role within the economic system. ${ }^{113}$ The location of the industrial quarter along the northern margins of the larger settlement area was probably a deliberate choice because of the fumes and smokes from the ovens and kilns, but it was also more convenient for trash disposal and expansion if needed.

At the southwestern edge of the desert-zone settlement, several buildings and associated structures have been excavated at locality HK 29, an area of about I.7 ha and one the best-studied areas of the early Predynastic town (see Figure 4.22). ${ }^{I 4}$ Two principal occupation phases can be distinguished, of which Phase I dates to the very early Naqada IIA period, while the second, later phase (II) is badly disturbed and dates to about Ioo years later. ${ }^{\text {II }}$ The first phase of occupation is characterized by several rectangular, semisubterranean buildings with light walls made in wattle-and-daub technique. Reed fences served as demarcations for larger yard-like areas, giving the settlement a rather loose organization with much open space around each area (Figure 4.22). A kiln consisting of eight shallow pits and measuring 6.I $\mathrm{m}$ by $5 \mathrm{~m}$ was discovered at about $5 \mathrm{~m}$ northeast to the main house. It had been used for the 

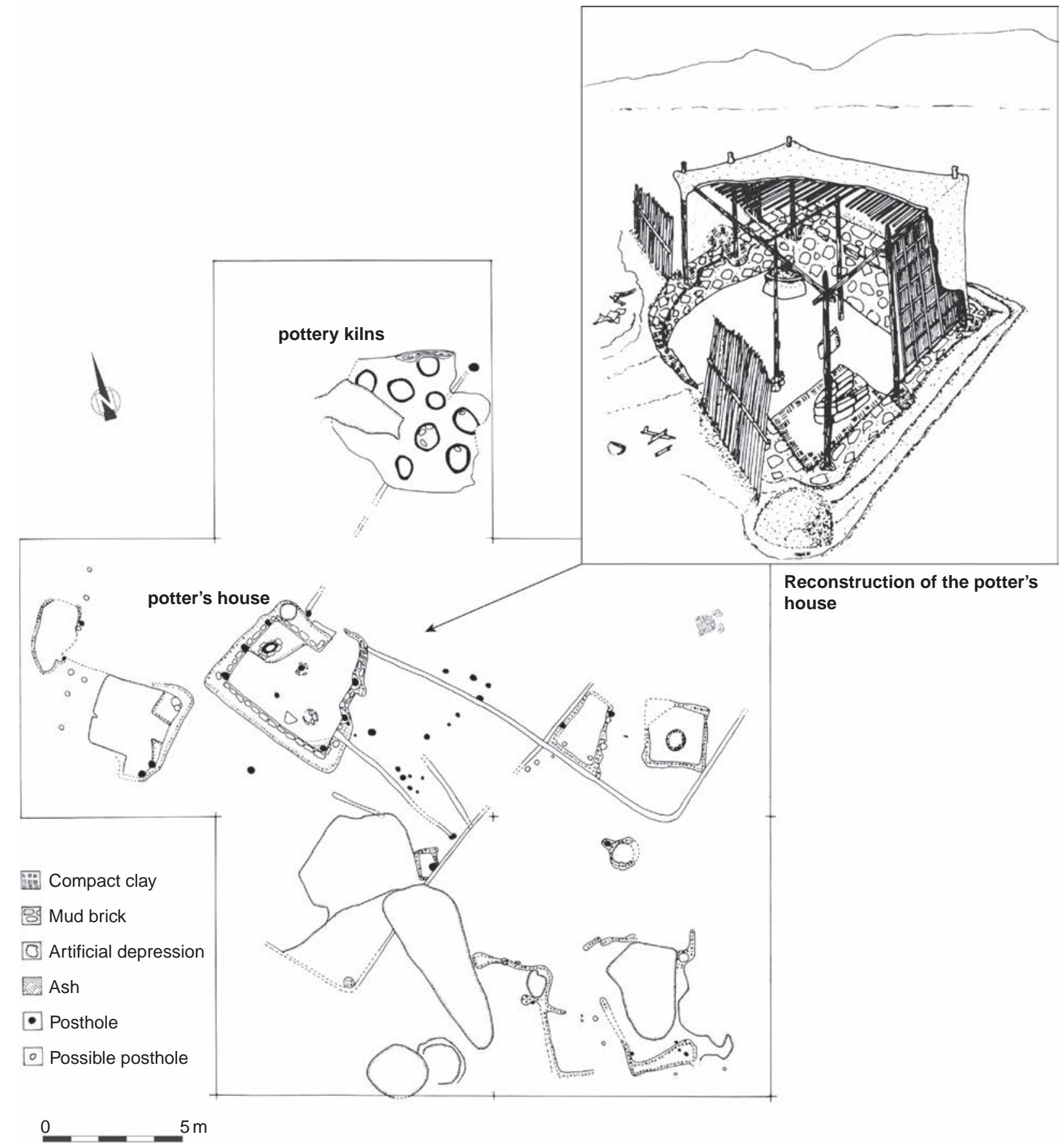

4.22. Plan of Phase I at HK 29 (Naqada IIA period) at Hierakonpolis. By G. Marouard, after M. A. Hoffman, "A Rectangular Amratian House from Hierakonpolis and Its Significance for Predynastic Research,” JNES 39 (I980), I32, fig. I2, and M. A. Hoffman, “The Predynastic of Hierakonpolis - An Intermin Report," Egyptian Studies Association I, I982, Cairo, I I, fig. I.2.

production of straw-tempered rough-ware pottery, exploiting a nearby clay source. Close to the kiln, remnants of several pottery basins were found that had been originally supported by firedogs - very similar to the setup of the brewery complex at $\mathrm{HK}$ I IC. ${ }^{\mathrm{I} 16}$ The presence of the vats and firedogs near the kiln provides good evidence for yet another example of the coexistence of a pottery production facility and a brewery.

The semisubterranean house associated with the pottery kiln has been published in depth because it was the 
best-preserved example at HK 29. ${ }^{\text {II }}$ It burnt down around 3650 BCE, resulting in an excellent preservation of the house and its related structures. The dwelling consists of a simple room, measuring $4 \mathrm{~m}$ by $3.5 \mathrm{~m}$, and its floor was dug into the ground ( $45 \mathrm{~cm}$ to $80 \mathrm{~cm}$ deep), giving it a semisubterranean appearance. The walls were fortified and smoothed by adding a layer of mud plaster mixed with broken pieces of mud bricks against the interior sides of the lower part of the building, into which several wooden posts were inserted for the upper part of the walls, which were finished using the wattle-and-daub technique coated with mud plaster (Figure 4.22). Inside the building, a hearth was found in one of the corners and a storage jar of straw-tempered rough ware still in situ, dug into the floor of the opposite corner. A negative imprint of a further storage vessel was noted near the outside of the building. ${ }^{\text {I } 8}$ These installations within the house provide evidence for food preparation and storage belonging to a single household. However, the pottery kilns the vicinity indicate that the owner of this small house might have been a potter and worked as a kind of specialist within the settlement. The analysis of the faunal and floral remains from this area shows evidence for the usual herding and agricultural activities most of the settlement's inhabitants were involved in. ${ }^{\text {I9 }}$ It is not possible according to the available evidence to discern in any more detail whether the potter of HK 29 was primarily a specialist and receiving supplies by others or whether he was also actively involved in agricultural work.

Further manufacturing areas clustered in the northwestern part of HK 29 were noted for examples of stone objects, foremost the production of flint tools and blades for domestic and other manufacturing purposes. Also found were a few mace-heads, stone vessels, and palettes, which are considered luxury items. ${ }^{\text {I20 }}$ This evidence points to the existence of certain areas used specifically for the production of various types of artifacts, utilitarian as well as decorative in character.

An additional matter of interest for this study is the evolution of the general organization in this part of the early Predynastic town. Whereas Phase I was characterized by a pattern of loosely arranged buildings and larger open areas, Phase II starts to show a much more dense arrangement of buildings using common walls. ${ }^{\text {I2 I }}$ This latter phase already consists of some elements that become increasingly frequent during late Predynastic and Early Dynastic periods at Hierakonpolis.

In conclusion, it is possible to state that the early Predynastic town dating to the period between 3800 and 3500 BCE spread between the low desert area and the wadis over an extensive zone covering more than 36 ha, which in fact constitutes the largest phase of settlement here. ${ }^{\mathrm{I} 22}$ It is characterized by a relatively dense settlement of people making best use of the local environment and depending on a subsistence economy of cereal agriculture and animal herding. At the same time there is first evidence for distinct quarters marked by production and manufacturing facilities along the marginal zones of the town. The excavated finds show that Hierakonpolis was already integrated into a larger network of exchange, witnessed by the presence of nonlocal raw materials. ${ }^{\text {I23 }}$

\subsubsection{The evidence from the late Predynastic} Period settlement at Hierakonpolis (Naqada IIB-III,

$$
\text { ca. 3500-3200 BCE) }
$$

The later Predynastic settlement underwent a process of nucleation and restructuring, resulting in a more compacted form of settlement at the modern edge of cultivation (see Figure 4.I9). It stretches for about $300 \mathrm{~m}$ along the desert edge, covering about 3.6 ha, but there is some evidence that parts of it might extend into the floodplain, where the ancient remains would now be covered by thick layers of alluvium. ${ }^{\text {I24 }}$ Hoffman refers to changes in the environment and climate that affected the inhabitants and led to this marked shift in the settlement toward the floodplain. ${ }^{\text {I25 }}$ Instead of the widespread, relatively open and dispersed character of the earlier settlement that covered a much larger area, the late Naqada II-period town shows increased density. Certain new urban elements can be recognized in the archaeological record. Evidence for an early ceremonial center has been discovered to the east of HK 29, at the locality called HK 29 A (Figure 4. I 8). ${ }^{\text {I }} 6$ The main feature of this structure is a large oval courtyard about $40 \mathrm{~m}$ long and $\mathrm{I} 2 \mathrm{~m}$ wide, made of a thick mud floor and surrounded by thin mud-brick walls and wooden fences of which numerous postholes in the ground bear witness (Figure 4.23). It functioned from the late Naqada II to the beginning of the Naqada III period; a few traces dating to the First Dynasty have been found that constitute the last phase of use here. The limits of the courtyard had been marked by a perimeter wall, which in turn had been fronted by a wooden fence construction along its exterior; only the trench remains. Several refuse pits were excavated on the eastern side of the trench, bearing witness of possible ritual activities performed inside the courtyard. 


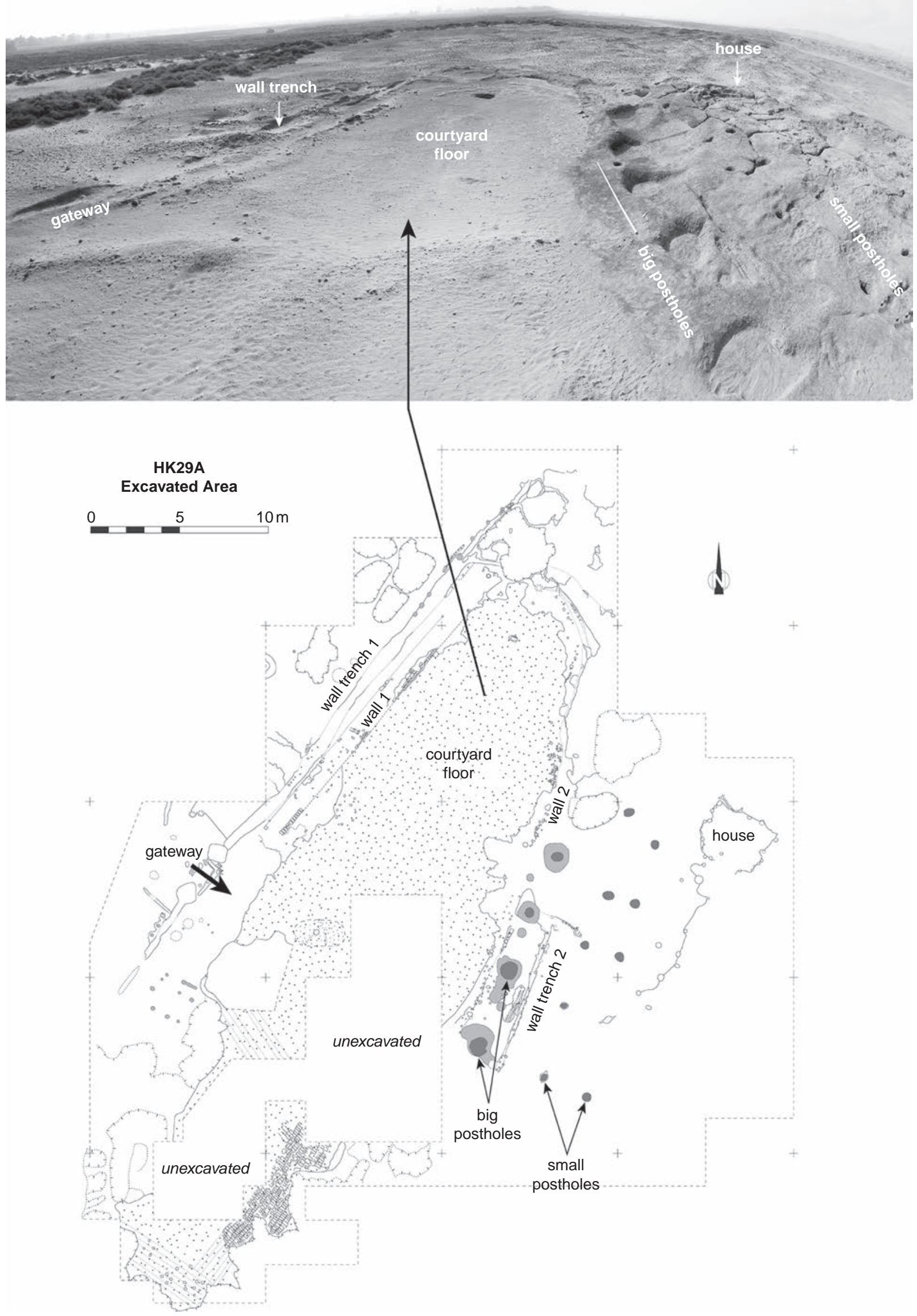

4.23. Early ceremonial center at HK 29 A (late Naqada II-early Naqada III period) at Hierakonpolis. Photo by R. Friedman, and plan by R. Friedman and L. McNamara, provided courtesy of the Hierakonpolis Expedition. 
Two postholes on the northwestern side mark the entrance to the oval courtyard. On the opposite side, four very large postholes for cedarwood posts were excavated; these measured about I.5 $\mathrm{m}$ in diameter. ${ }^{\mathrm{I} 27}$ Their exact function remains unknown, but for some time it had been assumed that they were for flagpoles standing in front of the shrine or sanctuary. However, recent reinvestigations in the area to the south of the postholes did not reveal any further traces of architectural remains except for two rows of four much smaller postholes that could have supported some light installations made of wood - maybe a kind of portico marking the entrance. ${ }^{\text {I } 28}$ This strongly suggests that the ritual activities were performed within the oval courtyard in the open area and not within a covered building. The remnants of such activities seem to have been discarded in various pits and the wall trench along the exterior of the complex, which was filled with a large number of pottery sherds and faunal remains. The analysis of the faunal remains showed evidence for the presence of cattle and sheep/ goat but also bones from wild species such as crocodiles, turtles, and large Nile perches. In addition, numerous flint tools have been found that provide evidence for the butchery of animals on site. ${ }^{\text {I29 }}$

The area to the north of the ceremonial complex has also been the object of recent archaeological investigations. At $\mathrm{HK} 29 \mathrm{~B}$ and $\mathrm{HK} 25$, additional evidence for structures was found in the form of numerous postholes (Figure 4.8). ${ }^{\mathrm{I}}{ }^{\circ} \mathrm{A}$ long palisade (HK 29B) stretching over $50 \mathrm{~m}$ and showing the same orientation as the ceremonial center seems to have been an additional element belonging to this cult complex. ${ }^{{ }^{3} \mathrm{I}}$ At HK 25, which lies to the northeast, five rows of at least ten postholes have been excavated, indicating the existence of a kind of large "pillared hall" here with some parallels to the columned structures at the elite cemetery at HK 6, situated along Wadi Abu Suffian. ${ }^{\text {I }}{ }^{2}$

The unusual architectural features, in combination with the finds of material culture and faunal remains, provide good evidence for an early ceremonial center that saw continuous use over more than 200 years. Its architectural elements, especially the large cedar poles, prove wider-ranging trade and economic connections, already established during this time period. They are also first evidence for architectural features of monumental size. Locality $29 \mathrm{~A}$ is good evidence for the transition to urban settlement toward the end of the fourth millennium BCE, and it falls precisely into the time period in which urban features began to appear in Upper and
Lower Egypt. While this early ceremonial center has no parallels at any other excavated settlement sites, its distinct architectural features (such as the oval courtyard and the four cedar posts) resemble images that can be found on decorative objects of the period (such as mace-heads or stone palettes as well as ivory tags with early writing). ${ }^{\mathrm{I} 33} \mathrm{It}$ has been tentatively identified with the Upper Egyptian $p r-w r$ shrine, known from First Dynasty sources as the most prominent cult center in the south. ${ }^{\mathrm{I}} 4$

Another building complex, which stands out from the rest of the late Predynastic settlement, is situated at HK $34 \mathrm{~B}$. Here a peculiar accumulation of stones was discovered lying on the summit of a small mound, which seems to have had a rectangular layout with a central courtyard. ${ }^{\mathrm{I} 35}$ Hoffman suggested that its prominent location on a mound in the center of a larger settlement as well its large size, covering about $\mathrm{I} 600 \mathrm{~m}^{2}-$ in addition to the building material that was predominantly made up of stone - mark it as an important complex, probably of administrative or ceremonial character. ${ }^{136}$ Another stone complex that has been dated a bit later, to the end of the Naqada III period, was detected at HK I5C (I) and has been termed "northern stone mound." During the survey conducted at this locality, remnants of a large building were noted. ${ }^{\mathrm{I}}{ }^{37}$ However, its bad state of preservation made it impossible for the archaeologists to distinguish individual rooms. Hoffman describes this structure as being a complex with thick walls and rooms organized in a "warren-like" fashion covering about $126 \mathrm{~m}^{2} .{ }^{138}$ Its precise purpose remains speculative, but its architecture indicates that it also served purposes other than primarily domestic functions.

Both of these stone constructions provide evidence for a certain variation and possible hierarchy among the buildings uncovered as part of the late Predynastic settlement along the desert edge. They fit into the development of increasing complexity and the presence of official buildings during this important time period that is marked by the emergence of urban features at the settlement of Hierakonpolis, which seems to reflect a more general trend in the wider region. The various elements and characteristics of the late Predynastic town allow a first evaluation of the "proto-urban" character of a settlement situated along the desert edge next to the floodplain and spreading over a considerable area. Distinct locations of specific settlement activity are recognized, with first evidence for monumental architecture that is witnessed, for example, at the early ceremonial center of HK 29A. Also important is the evidence for numerous 
specialized production areas from the early Predynastic Period onward, in some cases reaching industrial scale and combining the production of various commodities close to each other - such as bread, beer, and pottery, but also luxury objects and utilitarian stone tools. Such facilities have been found along the marginal areas of the settlement. Their presence necessitated to some extent the development of specialists whose main occupation would have been to produce staple foods, pottery, and stone objects. They probably received some support by other groups of inhabitants who were more actively engaged in agriculture. In addition, there is evidence for the manufacturing of specific funerary goods (e.g., special types of pottery vessels) and the supply of offerings in the form of beer, which was destined primarily for the funerary cult at the elite cemetery HK 6 that has been discovered along the Wadi Abu Suffian.

Around the main town, other sites of human settlement have been identified that were of more temporary nature - such as seasonal huts probably linked to herding and smaller hamlet-like installations. ${ }^{139}$ The main difference that Hoffman has pointed out between the early Predynastic phase and the later one is the gradual development to a much denser and agglutinated form of settlement toward the end of Naqada II/early Naqada III period, marking the beginning of the appearance of early urban features in settlements. ${ }^{10}$ Hoffman cites mainly environmental causes for these changes, some of which are related to human overexploitation of natural resources, but there was also a marked shift in the climate to drier conditions and a reduced intensity of Nile floods that favored the shift closer toward the floodplain.

\subsubsection{Ancient Nekhen - the city of the Early Dynastic Period in the floodplain}

The remains of a tell settlement at Kôm el-Gemuwia provides evidence for a compact walled town and its temple, dating to the Early Dynastic Period and the Old Kingdom. The tell is currently situated at about $360 \mathrm{~m}$ east of the desert edge within the floodplain and was the ancient town of Nekhen from the Early Dynastic Period onward (Figures 4.I 8 and 4.24). ${ }^{\mathrm{I} I \mathrm{I}}$

The gradual movement of habitation toward the floodplain was to some extent influenced by long-term climatic changes in the region (lower, less erratic and destructive floods, drier conditions in the desert). Although this shift seems to a widespread phenomenon

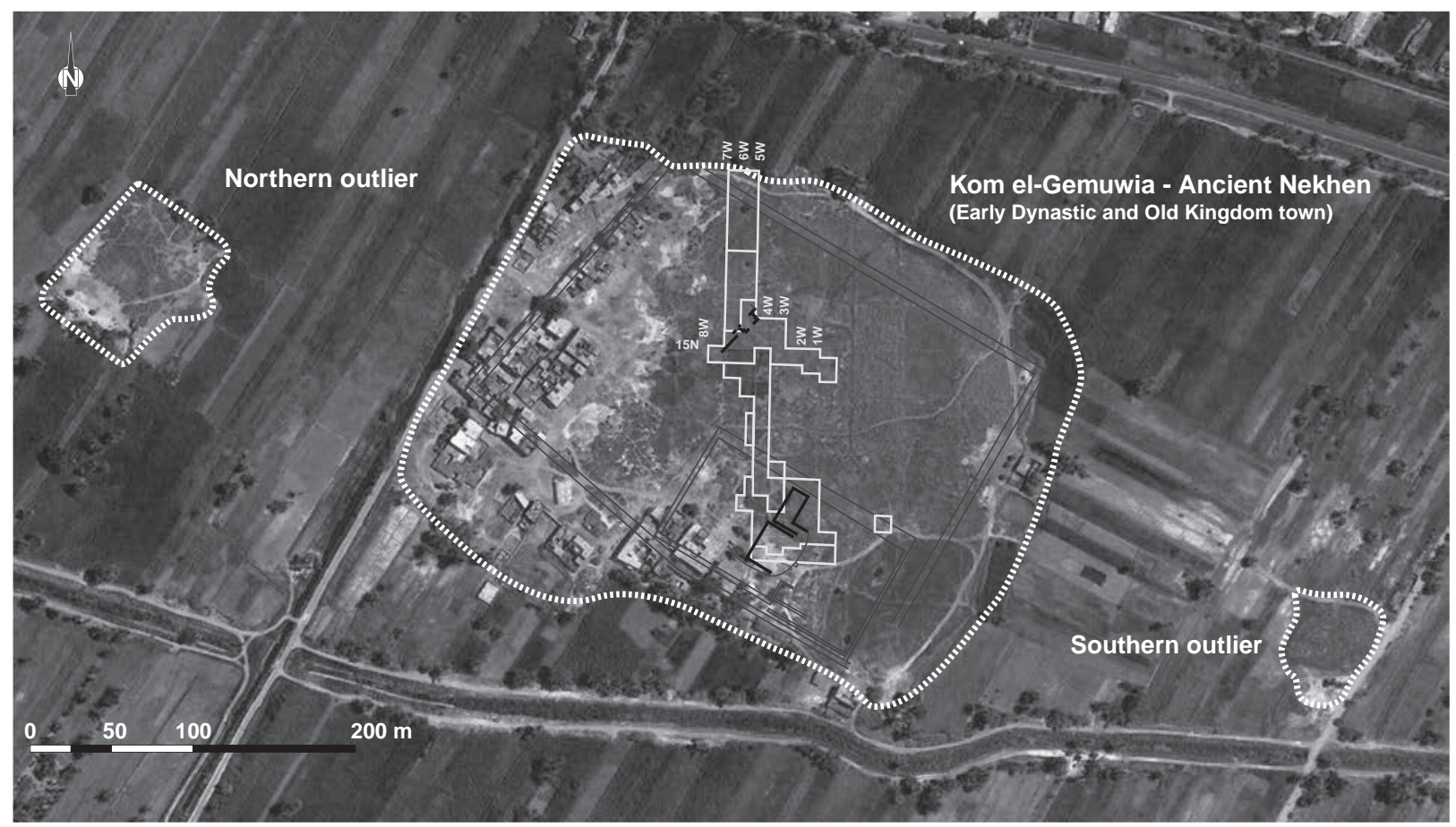

4.24. Satellite view (2009) of Kôm el-Gemuwia at Hierakonpolis, which shows the position of the excavation grid by W. Fairservis. By G. Marouard, using Google Earth ${ }^{\mathrm{TM}}$, image (C) 2014 DigitalGlobe. 


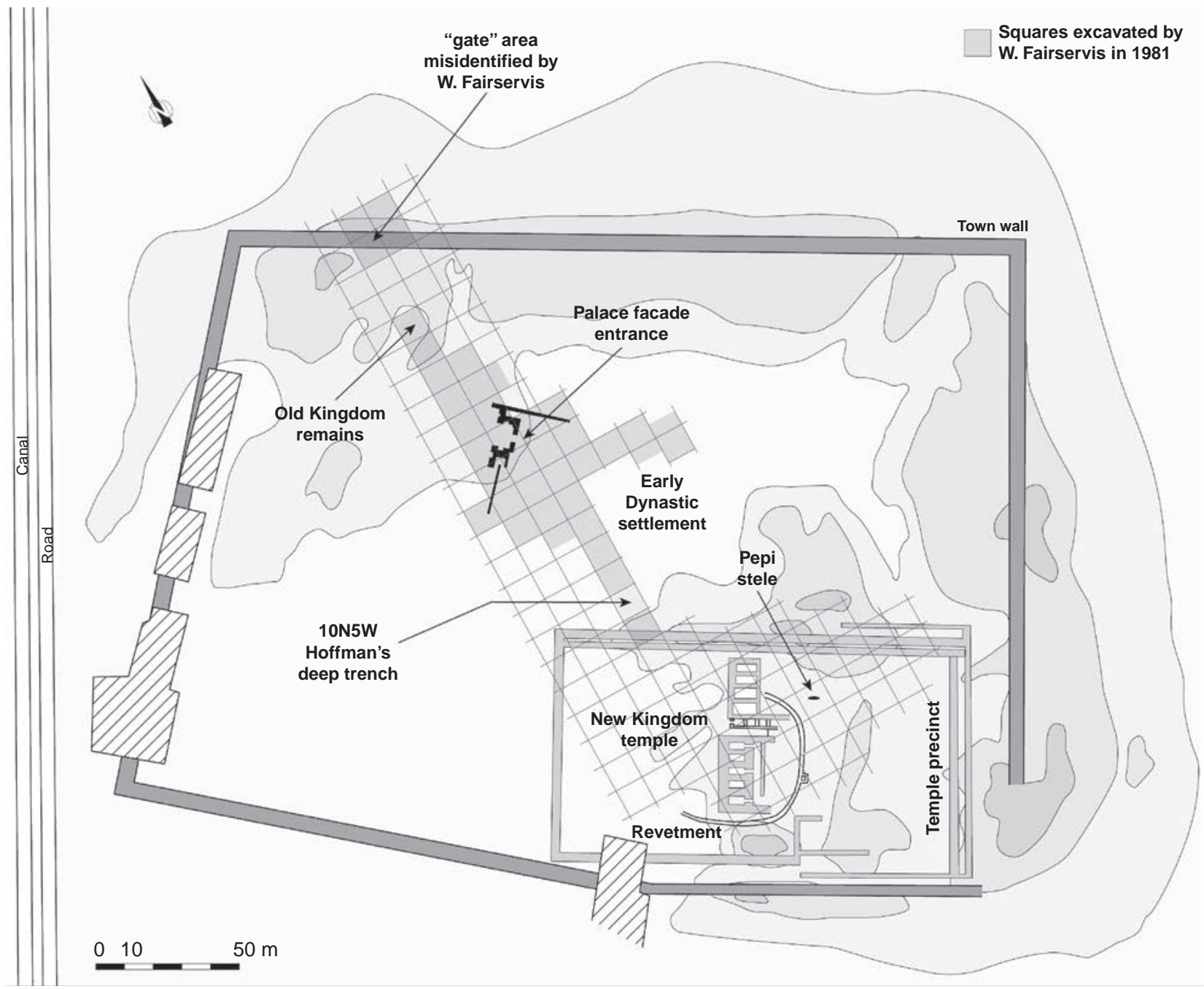

4.25. Plan of the grid laid out by W. Fairservis at Kôm el-Gemuwia (ancient Nekhen) at Hierakonpolis. By G. Marouard, after W. Fairservis, The Hierakonpolis Project. Season January to May 1981. Excavation on the Kôm el Gemuwia, Poughkeepsie, NY I986, fig. I.

also observed elsewhere, it is important to emphasize that the deep trench dug in square $\mathrm{IoN}_{5} \mathrm{~W}$ at Kôm el-Gemuwia shows clear evidence for settlement remains dating to the Predynastic Period underneath the later Pharaonic-period town (Figure 4.25). The various occupation phases and associated material culture provide a good chronological sequence that demonstrates that the later town of Nekhen at Kôm el-Gemuwia was not founded on virgin soil but seems to have been part of a continuous, long-term human occupation in this area. While these findings prove that some settlement in the floodplain existed at least from the Naqada II period onward, it is impossible to estimate the size and layout of the earliest settlement situated in the floodplain and its relation to the larger Predynastic town along the desert edge.

Apart from the archaeological remains in square IoN $5 \mathrm{~W}$ at Kôm el-Gemuwia itself, some indication about the possible size of the settlement in the floodplain during Predynastic times comes from the presence of two small mounds or outliers that have been noted at $200 \mathrm{~m}$ and $300 \mathrm{~m}$, respectively, to the east and west of the main town (Figure 4.24). Those two sites are still clearly visible on satellite images but have never received any in-depth investigation as to their date and nature. ${ }^{\mathrm{I} 42}$ Frederick W. Green gave a brief description about the outliers, and it seems to confirm Predynastic-Early Dynastic activity there: 
The little knoll seen to the S.E. of the town is an "outlier," having been surrounded by the encroachment of the cultivation. In it were found several jars of the prehistoric or early historic period. . . . The upper part of the knoll is composed of rubbish thrown from a pottery kiln. Much pottery of the early dynasties, such as rough vases with pointed bases, and rough pot stands, were found here, as well as a great number of fragments, partly fused and distorted by heat.

On the N.W. side of the town is another outlier in which many fragments of prehistoric pottery and flint flakes were found. ${ }^{\mathrm{I}} 43$

With this brief description provided by Green, it is possible to assume that these two outliers were further elements in the floodplain that provide some evidence for an occupation parallel to the desert settlements. It also raises the question to what extent it is possible that those outliers had originally been connected to the actual townsite in the floodplain or the desert settlement, maybe as part of a loosely spread town or city. ${ }^{\text {I } 44}$

The reason for the initial foundation of the Early Dynastic city of Nekhen in its current location within the floodplain is probably linked to two factors. There was an old wadi fan created by the large Wadi Abu Suffian that had led to the accumulation of a considerable amount of sand, creating some elevated ground. Nekhen might also have had convenient access to the Nile or a branch of the Nile flowing close to the site. ${ }^{\mathrm{I}} 45$

The site of ancient Nekhen in the floodplain at Kôm el-Gemuwia today is characterized by a low mound overgrown with halfa grass and a high groundwater level. In the past this site has seen several major excavations that not only brought to light objects of the Early Dynastic Period from the Main Deposit underneath a later temple construction but also parts of the actual Early Dynastic to Old Kingdom settlement. Although the temple was excavated first by Green and James E. Quibell at the end of the nineteenth century, they only investigated small parts of the actual settlement, which lies to the north of the temple. ${ }^{\text {I } 6}$ Their excavations are famous for the spectacular discovery of key objects in the so-called Main Deposit, such as the Narmer Palette. ${ }^{\text {I47 }}$

John Garstang continued the exploration of the temple and town in I905/1906, but he only published some very preliminary results. ${ }^{\text {I48 }} \mathrm{He}$ excavated within the northeastern corner of the main town wall, where he discovered remains of houses he dated to the Third Dynasty according to the ceramic evidence, but not many details are known from his fieldwork. ${ }^{\mathrm{I}} 49$ Concerning the general preservation of the ancient town and its surroundings, it is worth mentioning the existence of early reports of looting by the local population in order to supply the antiquities dealers in Luxor. This seems to have concerned the town and temple after Quibell and Green's work at the site in I899 and Garstang's brief intervention in I905. ${ }^{\text {I }}{ }^{50}$ Other reports mention organized gangs looting sites and cemeteries of various periods along the Western Desert between Edfu and Hierakonpolis.

The main focus of excavations concerning the actual settlement at Kôm el-Gemuwia started during the fieldwork directed by Walter Fairservis, who dug at Hierakonpolis from I967 to I98I. ${ }^{\text {ISI }}$ The results of this work provide some important insight into a part of the ancient townsite that dates to the Early Dynastic Period and early Old Kingdom.

\subsubsection{Excavation of the settlement at Kôm el-Gemuwia by W. Fairservis - enclosure walls}

Fairservis's aim was to work his way through an established grid of $20 \mathrm{~m} \times 20 \mathrm{~m}$ squares stretching from the town enclosure wall in the north to the temple enclosure (see Figure 4.25). As a starting point, he used the report by Quibell of the possible location of a gate along the northern edge (?) of the town mound, according to a depression visible on the surface. Fairservis started to excavate his first few squares in this area and was able to locate the remains of two town walls dating to different periods. ${ }^{152}$ The first enclosure (Wall A) had a thickness of 5.5 meters, to which a second wall (Wall B) was added on the outside, with a width of $2.5 \mathrm{~m}$. A gap of $\mathrm{I} .85 \mathrm{~m}$ separates the two. ${ }^{\mathrm{I}}{ }^{53}$

Fairservis also noticed that on both sides of the earlier, larger Wall A, various mud-brick buildings were abutting it on both the exterior and interior sides, which he takes as sign of later settlement activity when the actual wall had lost its function. ${ }^{\text {I54 }}$ The phenomenon of having mudbrick buildings leaning against the interior of an enclosure wall is fairly common for ancient Egyptian settlements. ${ }^{\text {I55 }}$ Another observation is the presence of a buttress-like addition on the inside of the wall whose tentative identification as a buttress remains questionable. ${ }^{156}$ The second wall (Wall B) was built later and shows some evidence for a decorative mud-brick pattern, possibly small niches, on its outside. ${ }^{\text {I57 }}$

The "gate" area described by Quibell and Green turned out to be a larger break or gap between the walls 
and is not a constructed gate. Fairservis did not immediately notice this, but he describes a "threshold" through the "gate" that was paved with mud bricks, and this pavement was to some extent bonded to the mud bricks of the enclosures. ${ }^{158}$ The "pavement" constitutes lower brick levels of the enclosures, which were preserved although the upper levels had been destroyed, leaving a gap. His observation that the bricks of the pavement were bonded to the enclosures are good evidence for this explanation, and it seems that he had noticed his error in his last report, in which he mentions a "break between walls built at different periods." 59

The later enclosure wall, Wall $\mathrm{B}$, made use of the remains of the older one, which were still to some extent preserved at the time of the construction. This is an interesting observation because it implies that the new town wall was not necessarily enclosing a larger settlement area but took advantage of the remains of the older enclosure in order to reach a total width of $9.5 \mathrm{~m}$. Concerning the chronology for both phases of enclosure walls, little evidence has been published. ${ }^{160}$ It is hard to find much information about concrete dates for both walls in the first report published by Fairservis, in which he describes his investigation of the town wall in detail. However, in his last report about the fieldwork results from I98I, he states that the older enclosure Wall A dates to the Old Kingdom, while the second enclosure, Wall B, might be New Kingdom in date. The fact that the latter was built close to the Old Kingdom enclosure with the same orientation and following the same course indicates that it is quite likely that these two constructions were built with less of a time gap than Fairservis suggested. ${ }^{\text {I6I }}$ On a more general level concerning the Early Dynastic and early Old Kingdom phases of the ancient town, he notes that

The area just south of the Town Wall from the grid point $25 \mathrm{~N}-8 \mathrm{~W}$ to a mid-point within quadrants I $7 \mathrm{~N}$ and I $8 \mathrm{~N}$ west of the Niched Gate appears to be Old Kingdom in date. The ceramic evidence suggests early Old Kingdom or Late Archaic (=ED) (Fairservis I97I-7I, figure 24). The more one moves northward towards the Town Wall, the greater the evidence ceramically for an Old Kingdom dating. This is also attested by the degree of the discontinuity of structures adjacent to the Archaic gate and those farther to the south (Fairservis I97I-72, figs. I 2, I 3). Even here, however, the orientation of newer walls still appears to conform to that of the older. This is the case with most walls which represent the later occupations. (Fairservis I986, 3)

Several further walls, which can be assigned to the category of enclosure walls according to their architecture and dimensions, were uncovered in other areas of the settlement site, but their precise function remains unclear because only a small area within the townsite was excavated to a larger extent. A large wall, for example, was discovered in square IoN $5 \mathrm{~W}$ by Hoffman's trench, but its precise function remains speculative. This square served as a test trench to investigate as deeply as possible the archaeological remains at Kôm el-Gemuwia, excavating underneath groundwater level in order to establish the earliest settlement remains here. ${ }^{162}$ Due to technical difficulties, the natural bedrock void of any material culture was not reached, but with the help of two drill cores and a deep sondage, the chronological framework was established, with the oldest objects in form of ceramics dating back to the early Naqada I period and the architectural remains dating later, to the end of the Naqada II period. ${ }^{163}$ Next to a wattle-and-daub structure of domestic character - which is characterized on the ground by postholes and thin trenches as well as two superimposed mud-floor levels representing two phases of use with evidence for various activities that can be inferred from the presence of an oven and clay-lined basins - a large mud-brick wall has been found. ${ }^{164}$ This wall is about $3 \mathrm{~m}$ thick and has been interpreted as a "large town or palace wall." Both structures, the domestic building and the large wall, seem to be contemporary and have been dated according to associated pottery to the transition between the end of Naqada II and the early Naqada III period. ${ }^{165}$ The wall is certainly too thick for a domestic building, and its identification as some sort enclosure seems correct. However, it is not possible to draw any firm conclusion on whether the settlement was already enclosed by a town wall during this time - too little of it has been exposed. Various other functions for this wall are equally possible. ${ }^{166}$ The main result of the excavations in square $\mathrm{I}_{0} \mathrm{~N}_{5} \mathrm{~W}$ is the confirmed presence of Predynastic settlement layers underneath the Early Dynastic and later town, but in order to investigate the nature and layout of the town during this time, and especially how it compares to the settlement along the desert edge, a much larger exposure of the archaeological remains would be needed.

The enclosure walls surrounding the temple area at Kôm el-Gemuwia that can be seen on most published 
plans date to the later Pharaonic period (see Figure 4.25). The visible enclosure wall at the temple that is founded on the Early Dynastic floor level is most likely of Eighteenth Dynasty date and was probably rebuilt in parts during the Ramesside period. ${ }^{\text {I67 }}$

This dating means that none of the visible temple enclosure walls are contemporary with the Early Dynastic occupation and the religious features of this time period are only known from buried cult objects such as those that have been found in the Main Deposit. The related architecture is much more difficult, if not impossible, to identify. Remains of a circular sand mound with a distinct stone revetment have been excavated underneath later temple structures. It seems to have functioned in relation with the earliest cultic activities carried out here, but its precise purpose and the nature of any additional architecture on top of the mound remain speculative. ${ }^{\text {I } 68}$ The desert settlement dating to the early and late Predynastic Period did not show any signs for mudbrick enclosure walls.

\subsubsection{The Early Dynastic building complex with the "palace-façade gate"}

In the I969 season at Hierakonpolis directed by Fairservis, a large gateway made of mud brick and showing a decorated exterior face with niches in the so-called palacefaçade style was discovered. It is located about halfway between the New Kingdom temple enclosure and the Old Kingdom town wall in an area that should have been the heart of the settlement (Figure 4.25). ${ }^{169}$ This discovery came as a big surprise, especially because palacefaçade decoration had mainly been found in association with funerary or religious architecture up to that time (e.g., Saqqara mastabas, Abydos enclosures; see discussion at Section 4.2.5, p. 76), which therefore has led to much discussion about the possible function of this building.

The largest exposure of archaeological remains was opened up around this feature, at the heart of Nekhen in squares ${ }_{7} 7 \mathrm{~N} 7 \mathrm{~W}-\mathrm{I} 7 \mathrm{~N} 6 \mathrm{~W}-\mathrm{I} 8 \mathrm{~N} 6 \mathrm{~W}$ (see Figure 4.26). According to the ceramic evidence, it has been dated to the Early Dynastic Period. ${ }^{170}$ This niched façade formed a sort of large gate, but the associated walls, which belong to the gate, have been difficult to identify. To the southwest runs a thicker mud-brick wall without any niching but with small buttresses at certain intervals (Figures 4.26 and 4.27). To the northeast, identification of any wall continuing in this direction has been difficult. Up to the discovery of the decorated mud-brick gate, all of the niched mud-brick architecture that had been known was almost exclusively connected to funerary contexts. This example is the first found within a settlement. From the published plan and the description of the archaeological discoveries in this area, it is clear that the inside consists of a multitude of thin mud-brick walls forming interconnected rooms and smaller courtyards. No individual buildings or streets are distinguishable.

The features within the various rooms included fireplaces, storage installations in the form of small silos or bins, ${ }^{17 \mathrm{I}}$ mud-plaster-lined pits, and sunken storage vessels in the ground. There is also some evidence for postholes and shallow negatives left in the floor from the deposit of pottery vessels. ${ }^{172}$ Little evidence points to anything other than domestic activities, but there are some exceptions that are noteworthy and one in particular that points to a building of official function. The following section discusses the installations and finds in this regard. It is necessary to review these features in more depth because they shed some light on the function of this building complex in the heart of the town.

\subsubsection{The niched gate}

The most striking feature is the gate area, which shows the palace-façade decoration on its exterior face (see Figures 4.26 and 4.27). The niched decoration marks a building complex of importance and potentially official character within the settlement. The opening of the gate itself has a width of about $2.8 \mathrm{~m}$, while the thickness of the walls on both sides varies between $0.88 \mathrm{~m}$ and $\mathrm{I} .9 \mathrm{~m}$ according to the niches. Its foundations were placed directly on a hardened mud surface without a foundation trench. ${ }^{173}$ The exterior and interior wall surfaces show traces of a thick mud plaster, which was once painted white. ${ }^{174}$ The reconstructed total height of the wall has been estimated at around $3.6 \mathrm{~m}$. To the south of the gate with the niched decoration, the wall continues in a southwestern direction, but without indicating niches. Instead, square buttress-like protrusions had been added to the exterior face (Figure 4.27). ${ }^{\mathrm{I}}{ }^{75}$ Here the wall is between I.O $\mathrm{m}$ and I.4 $\mathrm{m}$ thick. Along the outer face of the wall, a well-prepared mud-brick floor was discovered that had been covered by a layer of mud plaster (muna) in its first phase. On top of this floor, remnants of a stone pavement consisting of smaller sandstone pieces were observed. ${ }^{176}$ The northern continuation of the enclosure wall linked to the gate has been more difficult to identify. At first only a small wall stub (ca. $2 \mathrm{~m}$ long and $0.7 \mathrm{~m}$ wide) was found 


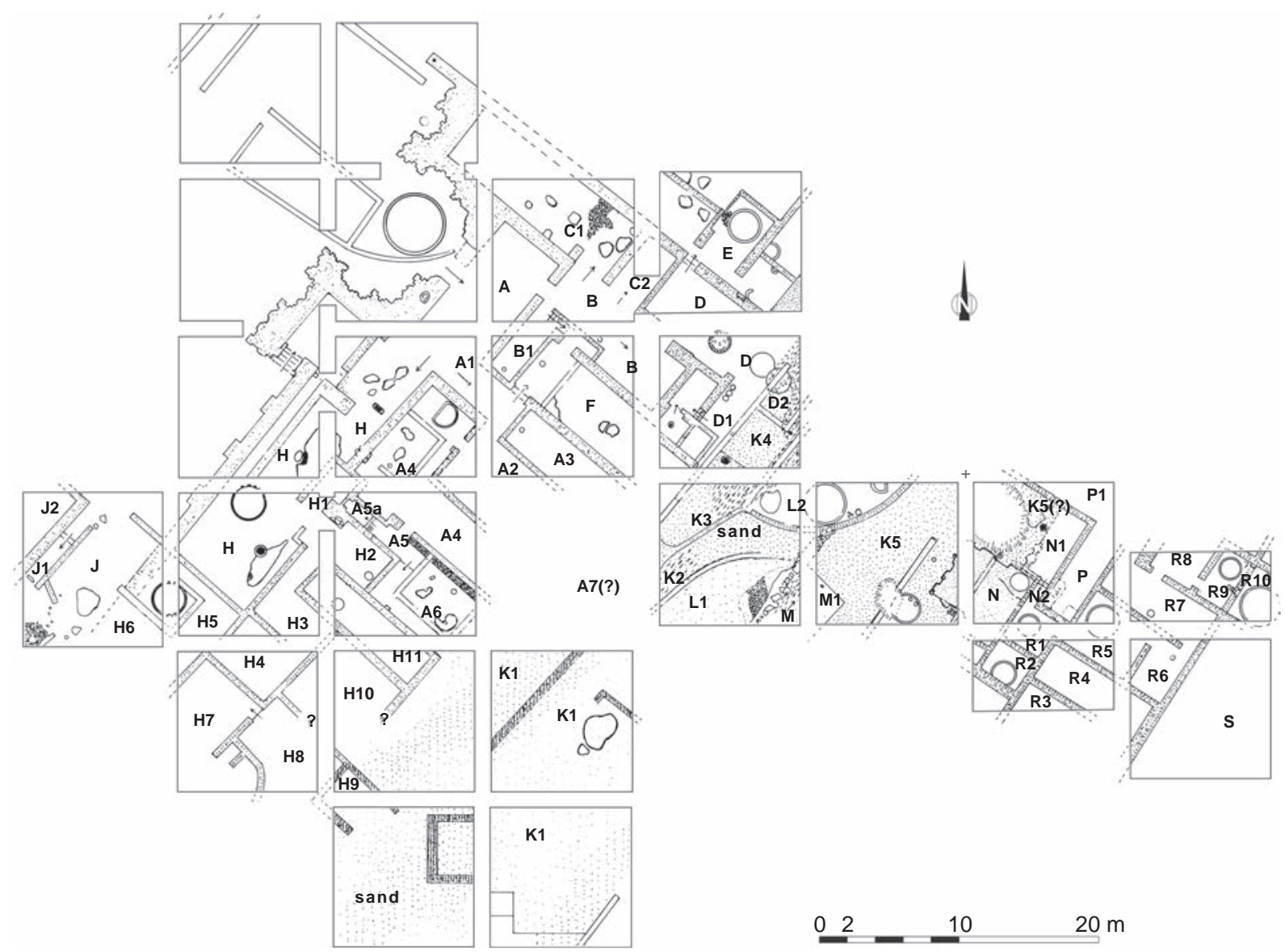

4.26. Plan of the Early Dynastic building complex at Kôm el-Gemuwia. By G. Marouard, after W. Fairservis, The Hierakonpolis Project. Season January to May 1981. Excavation on the Kôm el Gemuwia, Poughkeepsie, NY, I986.

that is directly linked to the northern end of the palacefaçade wall (Figure 4.27). A large posthole has been noted at the very end of this wall stub, and this hole might have held a kind of flagstaff according to the excavators. The wall stub seems to connect with another wall of identical dimensions that was found running in southeasterly direction (see Figure 4.26 , square ${ }_{17} \mathrm{~N}_{4} \mathrm{~W}$ ). If that identification is correct, then the niched gate was situated at the northwestern corner of the building complex. ${ }^{177}$

None of the walls that belong to the niched gate show any characteristics consistent with having been intended as a defensive wall (wall thickness, architecture). On the contrary, the palace-façade decoration and the small buttresses along the southern wall indicate a building of importance and are not part of a fortified enclosure wall. ${ }^{178}$ Also noteworthy in terms of general structural observations is the fact that the excavated floor levels seem to gradually rise from the gate in a southern and eastern direction. ${ }^{179}$
Even though the full extent of the enclosure wall with the niched gate is unknown, the archaeological evidence so far points to the gate being located at the northwestern corner of the complex. Close parallels for this location and also the architecture come from the Early Dynastic funerary enclosures at Abydos, where the remains of the northern gates of Djer, Peribsen, and Khasekhemwy show a striking resemblance to the gate at Hierakonpolis. ${ }^{180}$ However, the latter gate area is part of an urban setting, in contrast to the Abydos examples, which are clearly of a funerary nature.

\subsubsection{The interior layout of the palace-façade complex}

The interior arrangement is characterized by a large number of interconnecting rooms and passages without the demarcation of any particular hierarchy. Apart from the expected objects and features associated with regular settlement activity - such as grinding stones, pottery, flint 

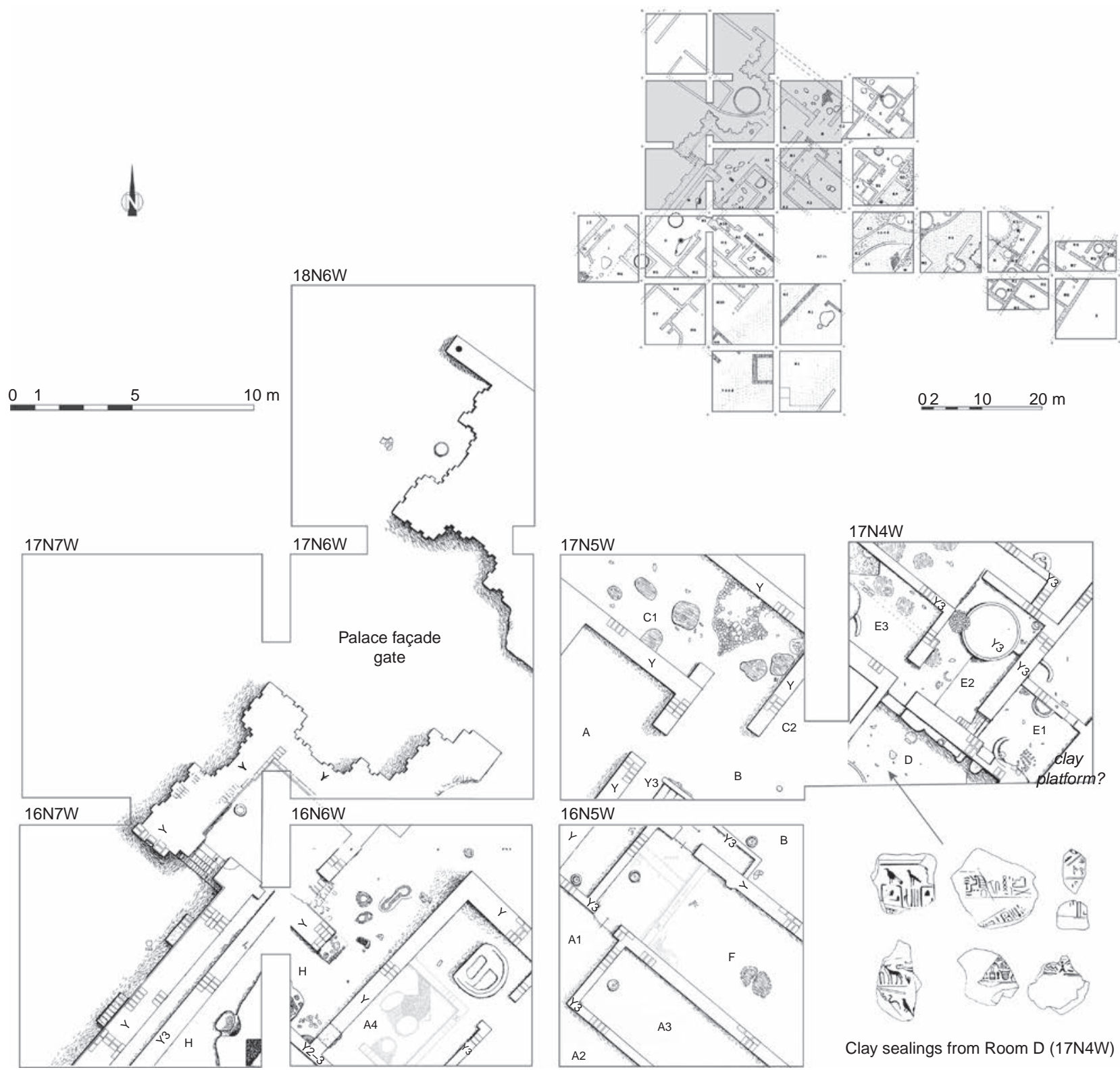

4.27. Detail of the palace-façade gate of the Early Dynastic building complex at Kôm el-Gemuwia. By G. Marouard, after W. Fairservis, The Hierakonpolis Project. Season January to May 1981. Excavation on the Kôm el Gemuwia, Poughkeepsie, NY, I986.

tools, fireplaces, and round storage installations-several areas stand out and have the potential to reveal more about the function of this building complex.

In squares ${ }_{1} 5 \mathrm{~N}_{3} \mathrm{~W}$ and ${ }_{1} \mathrm{~N}_{2} \mathrm{~W}$ and at a distance of about $40 \mathrm{~m}$ southeast of the palace-façade gate, in what should be the inner heart of the building, a large mud-brick platform has been found that also showed a niched or buttress-like decoration along its base. ${ }^{\text {I8I }}$ This platform lies in the direct axis of the palace-façade gate, which is important evidence for its official and representational character (see Figure 4.30). There are several segments of this platform ( $\mathrm{N}$ and $\mathrm{N}_{\mathrm{I}}$; see Figure 4.30), which are separated by thin mud-brick walls and linked via doorways on the south to room $\mathrm{N} 2 .{ }^{182}$ The most prominent platform part $(\mathrm{N})$ is about $4.2 \mathrm{~m}$ long and $4.7 \mathrm{~m}$ deep, while the slightly smaller part situated to its northeast side $(\mathrm{NI})$ is $4 \mathrm{~m}$ long and $2.2 \mathrm{~m}$ deep. Its face was decorated by a simple niche pattern, and several postholes on top of the platform might have held flagstaffs (Figure 4.30). ${ }^{183}$ 

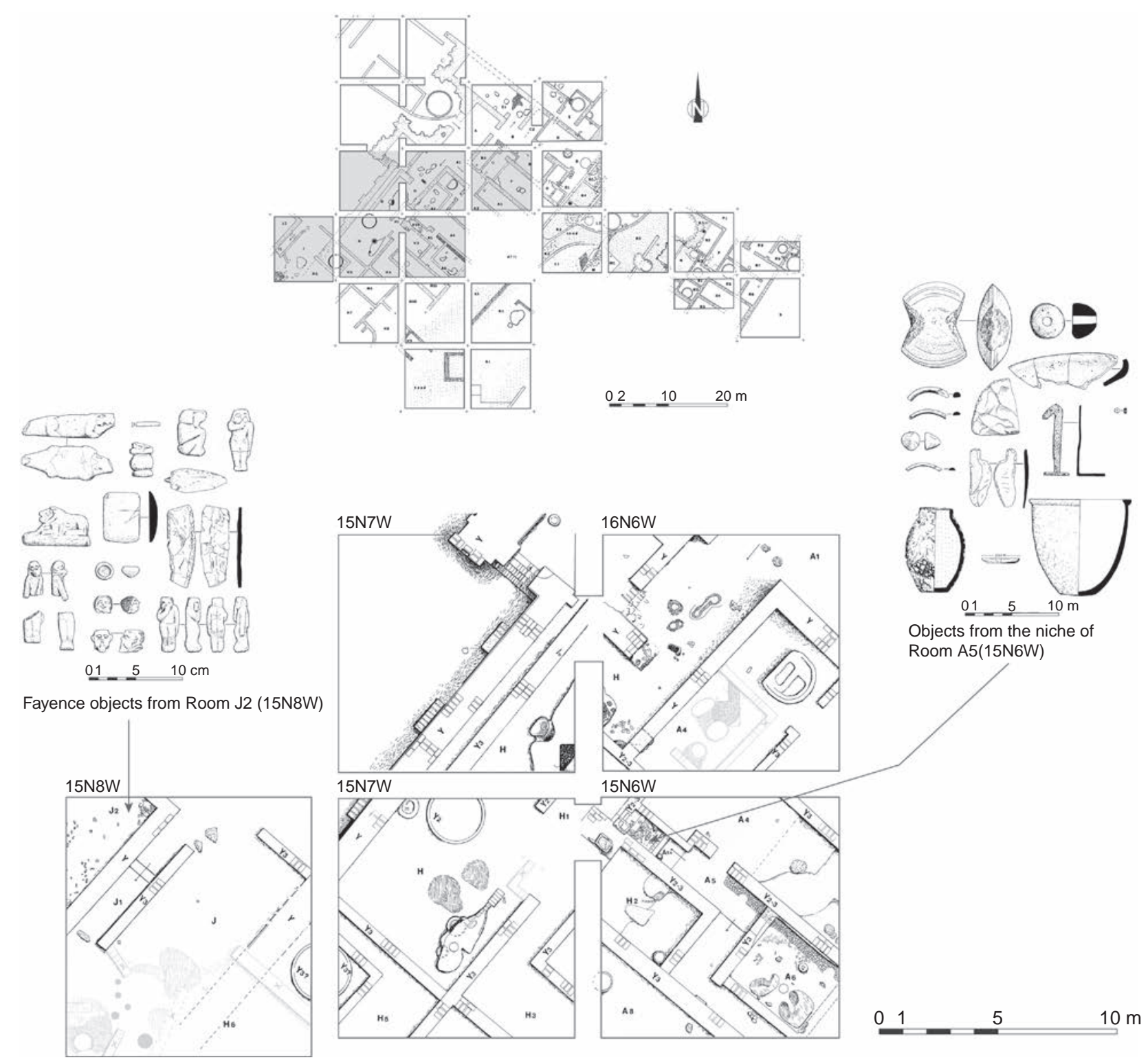

4.28. Detail of the Early Dynastic building complex at Kôm el-Gemuwia. By G. Marouard, after W. Fairservis, The Hierakonpolis Project. Season January to May 1981. Excavation on the Kôm el Gemuwia, Poughkeepsie, NY, I986.

A corridor-like room ( $\left.\mathrm{N}_{2}\right)$ at the rear of the platform gave access to the adjacent rooms, which according to the reconstruction are all at the same elevation. ${ }^{184}$ About four rooms show round silos at their centers, and therefore the platform installation has been interpreted in the context of a large storage facility. It is not clear, though, whether the silos and some of the thin partition walls were part of the original layout or later additions to it, which is, for example, suggested by the fact that some of these round silos are constructed in the center of passages leading from one room to another (see Figure 4.30, RI). As the current evidence stands, it is quite likely that the round silos are later additions and do not belong to the original layout of the platform.

Fairservis suggested that the platform might have been some sort of "loading ramp" in connection with administrative activity, which he relates to the presence of the silos. ${ }^{185}$ The whole platform installation certainly does not resemble any regular domestic structure, and its niched decoration indicates some official purpose, which is further emphasized by its location and orientation in relation to the palace-façade gate. The interpretation as a loading 
THE ORIGINS OF URB A N S C I E T Y
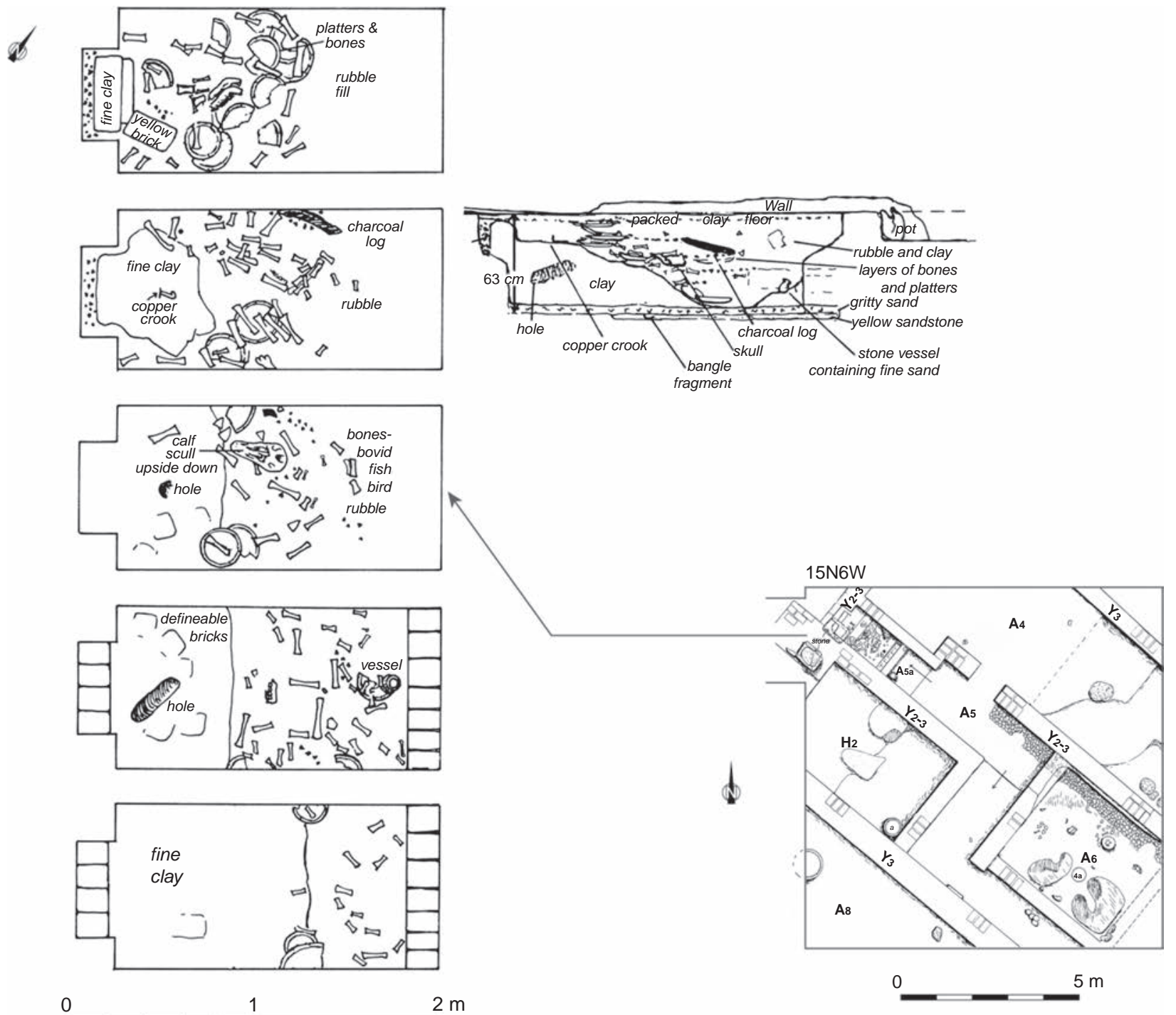

4.29. Stratigraphy of the deposit inside the niche of Room As (Square $i_{5} \mathrm{~N} 6 \mathrm{XW}$ ) at Kôm el-Gemuwia. By G. Marouard, after W. Fairservis, The Hierakonpolis Project. Season January to May 1981. Excavation on the Kôm el Gemuwia, Poughkeepsie, NY I986, fig. 20.

ramp for a large storage facility is therefore quite unlikely. The architectural details indicate some official or representational function - for example, to inspect goods or receive audiences. Its link to administrative activity, however, also remains a good option, especially in comparison with later images of high officials inspecting the delivery of goods. ${ }^{186}$

Additional evidence pointing to an official/representative character of the platform is seen in a stone balustrade or some kind of ramp, of which there are several elements remaining that seem to have been leading up to the platform construction and have been found at about I 5 m southwest of it (Figure 4.30). The "ramp" was built of a lower layer of roughly cut sandstone blocks and covered by thin sandstone slabs, which in turn were covered by well-cut rectangular limestone blocks showing recessed panels carved on their sides. ${ }^{187}$ This peculiar stone structure runs parallel to both the platform and the niched gate and faces an open area or courtyard in front of the platform (see Figure 4.30).

Evidence for a small cult place was also found in the interior of this building complex (Figure 4.28, niche of room A5). A small niche enclosed on three sides by mudbrick walls was discovered at about Io $\mathrm{m}$ south of the palace-façade gate in square ${ }_{15} \mathrm{~N} 6 \mathrm{~W} .{ }^{188}$ Numerous layers associated with offering deposits consisting of various objects - foremost pottery vessels such as large trays 


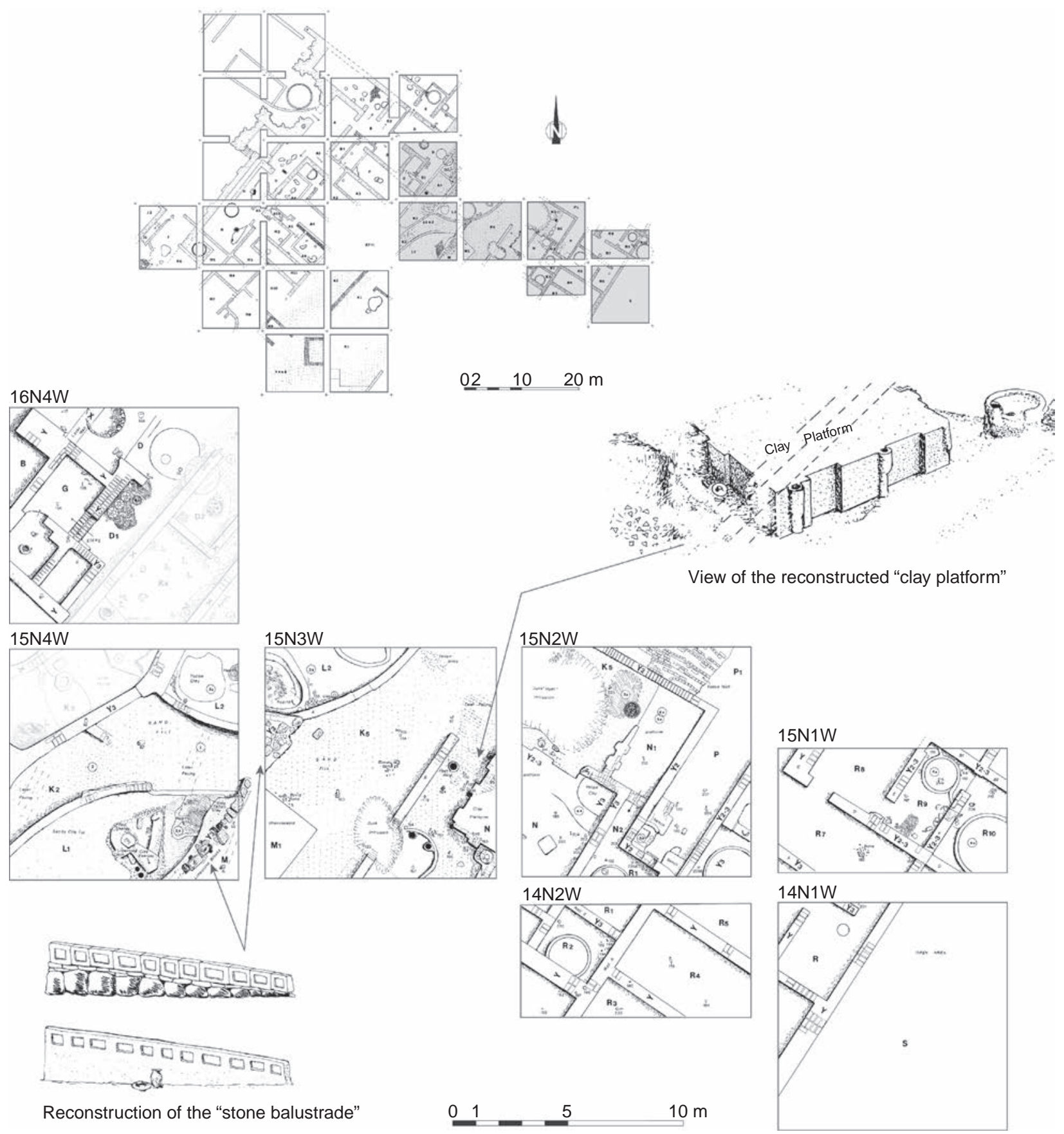

4.30. Detail of the "clay platform” area, Early Dynastic building complex at Kôm el-Gemuwia. By G. Marouard, after W. Fairservis, The Hierakonpolis Project. Season January to May 1981. Excavation on the Kôm el Gemuwia, Poughkeepsie, NY, I986.

and a considerable amount of animal bones - were found here (see Figure 4.29). These finds are good evidence for the regular presentation of food offerings in this small shrine over some period of time, but it has not been possible to identify the recipient of the cult. There was also a complete absence of any small animal or human figurines among the offerings, and these elements are typically found in the contexts of early shrines. ${ }^{189}$ However, such figurines have been excavated in a different location at the site. Numerous examples were discovered in a building situated southeast of the palacefaçade gate that has been identified as a faience 
workshop. ${ }^{190}$ Only the northwest corner of this building has been exposed, and it lies opposite the currently known southern end of the buttressed enclosure wall extending south of the palace-façade gate (see Figure 4.28 , square ${ }_{15} \mathrm{~N} 8 \mathrm{~W}$, room $\mathrm{J} 2$ ).

There is also some evidence for inscribed materials, notably in the form of broken clay sealing fragments, that provide good evidence for administrative activity having taken place in the palace-façade building complex. Several inscribed sealings were found in association with the floor of Room D (squares ${ }_{17} \mathrm{~N}_{4} \mathrm{~W}$ and ${ }_{1} 6 \mathrm{~N}_{4} \mathrm{~W}$; see Figure 4.27). This large room or courtyard lies about I $2 \mathrm{~m}$ to the east of the niched gate and is characterized by the presence of a large circular hearth at its center. ${ }^{191} \mathrm{On}$ its mud floor, seven pieces of broken sealings were found that come from jar stoppers. ${ }^{192}$ One of them shows the serekh with the name of Qa'a, last ruler of the First Dynasty (Figure 4.27, clay sealing no. I28). Three additional sealings were found in squares ${ }_{7} 7 \mathrm{~N}_{7} \mathrm{~W}-6 \mathrm{~W}$ just outside of the niched gate and might be slightly later in date. Two of them were fragments of clay jar sealings showing cylinder seal impressions, while the third was probably a document sealing. ${ }^{193}$

The sealings provide evidence for the official nature of this large building complex and suggest some links to the Early Dynastic rulers. Some of the structures outlined previously that lie within the interior of this complex provide additional support for its interpretation as an early palatial complex, possibly for a local/regional ruler or chief residing at Nekhen.

Although there is ample evidence for seemingly "domestic" activities such as food preparation areas witnessed by ovens and hearths, pottery, and storage installations, there is little doubt about the official and administrative component/function of this building. This observation is validated by the niched enclosure and elaborate gate but also by the presence of the platform in the center of the building. The arrangement of interlocking rooms leaves no possibility of identifying any smaller individual or self-contained structures within the complex; the whole layout seems to consist of an endless succession of small rooms, courtyards, and corridors that, however, excludes the notion that the palace-façade gate was in fact the first town wall of Nekhen. The discovery of the elaborately decorated gate area has led to speculations whether this complex could have been originally a religious structure and the interlocking mud-brick walls on the inside a later addition that was not related to the enclosure. ${ }^{194}$ The evidence for the general stratigraphy of the site presented by Fairservis in his reports is not necessarily ideal, but there is no reason to question the main lines of his analysis and associated chronology of the archaeological remains. ${ }^{195}$ It is reasonable, then, to accept the contemporaneity of the palace-façade gate with the mud-brick walls on the inside. According to the finds and the architectural specifics of this building complex, the only plausible interpretation of its function lies in the official and administrative sphere, in addition to the evidence for residential use as witnessed by the storage installations and traces of food preparation and cooking. It should therefore be considered a secular building probably a kind of "palace." "196

Apart from its residential function, the platform installation in conjunction with the balustrade construction and the open courtyard in front of it, among other features, indicate that official business was dealt with in this building, which is further corroborated by the presence of clay sealings. The discovery of the small household shrine that does not display any formal features could be first evidence for a so-called ancestor cult that allowed for the veneration of deceased family members and acted as a point of communication between the living and the dead. ${ }^{197}$ It is also possible that this palatial complex is an early example of the later governor's palaces or residences that have been part of important provincial capitals and can be considered an urban feature.

Concerning the date of this complex, an Early Dynastic date seems likely with respect to the pottery evidence and the clay sealings. ${ }^{198}$ In addition, excavations conducted below the platform revealed occupational layers dating to Naqada IIIB (= Dynasty o), which can be considered a terminus post quem for the platform, making an Early Dynastic date for the latter a likely option. ${ }^{199}$

The above-mentioned parallels of the entrance gate to the northern gates of several Early Dynastic funerary enclosures make a strong case for the Abydene enclosures being modeled on "palatial" complexes from settlement contexts. Specific architectural features and building styles that have their origins in settlement contexts were evidently transposed into the funerary and religious sphere.

The function of the palace-façade gate at Hierakonpolis as an enclosure demarcating an official administrative and residential building is a rare piece of evidence for this influence of urban constructions on funerary architecture. It is clear that the way archaeological evidence comes to be preserved has an enormous effect on the possibilities for deciphering such evidence. Very little is known about 
these early townsites, whereas the structures belonging to the funerary sphere are often much better preserved due to their location in the desert and along the desert edge.

\subsubsection{Conclusions about the character of ancient Nekhen}

The archaeological finds from the excavations at Kôm el-Gemuwia provide good evidence for the presence of an important early urban center in Upper Egypt - one that already shows some of the principal elements that become typical for provincial capitals in the following periods. The Early Dynastic Period is certainly a formative time for the development of compact towns within the floodplain, which begin to exhibit urban elements such as a major temple and an important administrative complex that was possibly also an official elite residence for the local mayor or governor of the town. The palacefaçade gate clearly sets apart a large building complex from the rest of the settlement. Some of its interior layout stands out, including that of the platform installations and the balustrade, whereas the overall arrangement of interconnecting rooms, passages, and open areas does not seem to be in any way different from that of buildings on the exterior of the complex. A similar observation has been made at the Early Dynastic fortress at Elephantine, where the interior of the fortress does not show a different layout of buildings compared with those found within the settlement next to the fortress. In addition, a major system of streets, for example, does not seem to have developed in any formal way that would allow for the differentiation in the archaeological record of any main streets through the town with smaller side streets. Although it is difficult to compare some of the results from Hierakonpolis with those of other sites in Egypt simply because there is little information from Early Dynastic settlements available in general, some of the characteristics surrounding the agglutinated layouts without any clear infrastructure are also visible at Elephantine.

The large town enclosure wall at Kôm el-Gemuwia that is depicted on most plans of the site is of Old Kingdom date and therefore later than the palace-façade gate. However, according to the ceramic evidence, it appears that the last phase of occupation of the associated building complex continued into the early Old Kingdom. ${ }^{200}$ While the presence of an Old Kingdom town wall is evident, no town enclosure wall has been identified for the Early Dynastic town. The existence of such early town walls has so far been attested at Elephantine, where the fortress is gradually incorporated into the settlement enclosed by fortified walls, as well as at Tell es-Sakan, a site considered an Egyptian outpost that was also surrounded by mud-brick fortifications. Whether this phenomenon is only restricted to settlements situated in the border regions is currently difficult to evaluate with any certainty.

Equally important is the evidence for a major temple at the site of ancient Nekhen, which according to the finds of the Main Deposit was of national importance and closely connected with early kingship. Architecturally, little evidence has been found for it underneath later walls and remains of sanctuaries except for the so-called revetted mound, whose precise function remains unknown. ${ }^{201}$

In conclusion, it is possible to state that the early settlements at Hierakonpolis not only provide much information about the origins of urban society in Egypt during the late Predynastic Period but also confirm that already during the first two dynasties, fully developed towns appeared in the Nile Valley. All the principal elements for a town of urban character are present at ancient Nekhen.

\subsection{EVIDENCE FOR AN EARLY DYNASTIC BUILDING COMPLEX AT BUTO}

\subsection{The geographical setting}

Archaeological settlement remains dating to the Early Dynastic Period have been found at the site of Buto, an impressive mound situated in the northwestern part of the Nile Delta. Today, the site lies about $40 \mathrm{~km}$ inland from the Mediterranean seashore. In I999, the German Archaeological Institute in Cairo (DAIK), under the direction of Ulrich Hartung, conducted a thorough survey of the entire settlement, which encompasses an area of about $\mathrm{I} \mathrm{km}{ }^{2} .{ }^{202}$ Most of the archaeological remains that are visible today cluster around three mounds (Kôm $\mathrm{A}, \mathrm{B}$, and $\mathrm{C}$ ) and are primarily of Ptolemaic and Roman date (Figure 4.3I). However, the importance of Buto goes back much earlier - namely to the late Predynastic and Early Dynastic periods - which is also known from written sources. Buto can be identified with the twin cities of Pe and Dep, two toponyms abundantly attested on seals and sealings. It has been assumed that Buto had the role of the archaic capital of Lower Egypt during that time, thus a major center in the Delta. ${ }^{203}$ Finding archaeological evidence in order to confirm this status has been difficult because of the remains being deeply buried under 


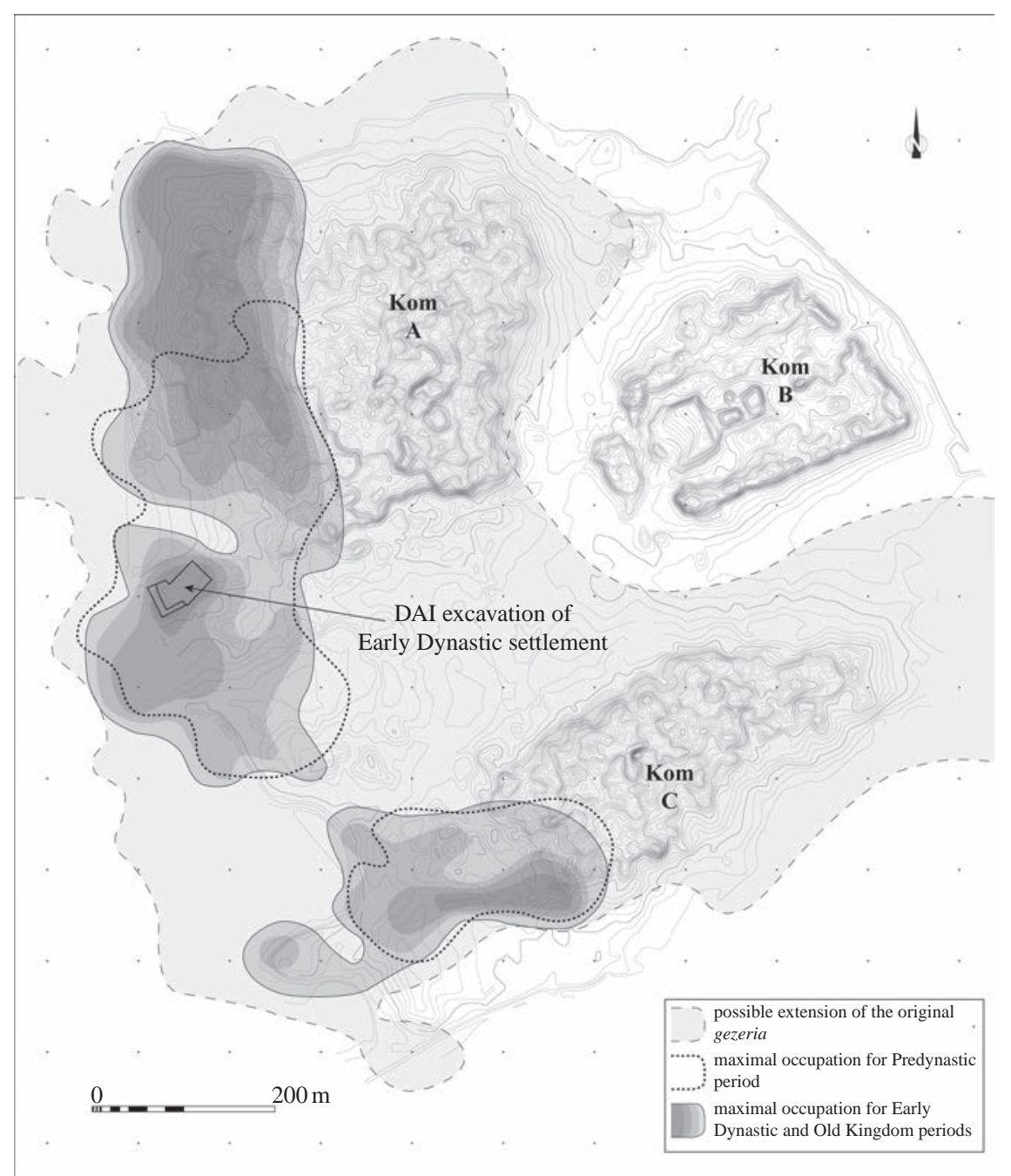

4.3I. General plan of Buto and restitution of the possible limits of the occupation from the Predynastic Period to the Old Kingdom. By G. Marouard, after U. Hartung, et al., “Tell el-Fara'in - Buto. Io. Vorbericht,” MDAIK 65 (2007), 85, Abb. I.

thick layers of alluvium and later settlements. An extensive drill-core survey at the site has shed some light on the location and evolution of the Predynastic and Early Dynastic settlement. Evidence for the earliest settlement activity of the so-called Buto-Maadi culture is mainly present in the southwestern part of the site, near the modern village of Sekhemawy. During the following Early Dynastic Period, this settlement spread farther to the north (Figure 4.3I). ${ }^{204}$

The questions about the reality of Pe and Dep and what might be present in the archaeological evidence for these towns had already intrigued William M. Flinders Petrie in I $886 .{ }^{205}$ Petrie describes a visit to the site, joining Charles T. Curelly, who dug several trial pits at the townsite. Curelly mainly discovered Roman settlement remains, but several Early Dynastic stone vessels were noticed, which made Petrie believe that there was a much earlier settlement somewhere underneath. There were only sporadic finds in the following fieldwork seasons under various directors, and it was not until the early 1980 os that more-substantial evidence for an early town was uncovered. Werner Kaiser initiated the project, and the work continued for several seasons under the direction of Thomas von der Way. With the help of a drill-core survey, the presence of early settlement layers underneath the much later occupation was finally confirmed, and excavations then started along the western side of the tell. During this fieldwork, settlement layers of the Early Dynastic Period were discovered, centering on a large Early Dynastic building complex of official 
nature. ${ }^{206}$ Farther below, settlement remains assigned to the Buto-Maadi cultural complex of the fourth millennium BCE were excavated. ${ }^{207}$ The excavations in this area were expanded when Hartung took over the direction of the project in I999. He also conducted a successful drill-core survey covering the whole site, which led for the first time to a more in-depth understanding of the location, its nature, and its development from the earliest settlement dated at the fourth millennium BCE to the large city of Roman times, taking into account the changing environmental conditions. ${ }^{208}$

The earliest settlement at Buto was located along the western edge of a large Holocene dune ridge adjacent to a water channel, which was probably one of the Nile branches (Figure 4.3I). ${ }^{209}$ Higher ground was sought for habitation because of the perennial inundation affecting the lower-lying ground. Later, during the Early Dynastic Period, the settlement area saw a considerable enlargement toward the north, while the river course remained unchanged in the immediate vicinity. ${ }^{2 \text { Io }}$ Important to note is the steady growth of the settlement deposits from $\mathrm{I}$ to $2 \mathrm{~m}$ in thickness during the Predynastic period to about $5 \mathrm{~m}$ by the Early Dynastic time. Apart from some sparse Old Kingdom evidence, nowhere on this large settlement site have any traces been discovered up to the present for Middle Kingdom or New Kingdom activity, which indicates a long phase of abandonment until the Third Intermediate Period.

\subsubsection{The Early Dynastic building complex}

The large building complex first discovered by von der Way has been excavated since 2000 in a more extensive way, with the aim of gathering additional data about the complete layout. The area was enlarged to about $\mathrm{I}, 500 \mathrm{~m}^{2}$, including the earlier squares excavated by Hartung's predecessors. All of the mud-brick walls that have been dug in this part of the site belong to one large building complex, with a width of at least $58 \mathrm{~m}$, extending for more than $45 \mathrm{~m}$ in a north-south direction, and also consisting of three or possibly four discrete areas resembling wide rows, each separated from the other by a thicker dividing wall (Figure 4.32). The arrangement of the larger internal dividing walls that separate the individual areas give the whole building complex a somewhat symmetrical layout. ${ }^{2 \text { I }}$

The central feature of the complex is a long corridor or courtyard of considerable width $(4.8 \mathrm{~m})$, flanked on the eastern and western sides by two larger mud-brick walls that are three courses wide, measure about $\mathrm{I} \mathrm{m}$ in thickness, and end to the south in a gate area flanked by two large protruding walls, each about $\mathrm{I} .4 \mathrm{~m}$ to $\mathrm{I} .6 \mathrm{~m}$ wide (see Figure 4.32). ${ }^{212}$ From there, continuing in a southern direction, the interior of the central part of the building in the form of a courtyard became accessible, which provided access to the western and eastern parts of the complex (see Figure 4.32, Areas I and 2). These two areas, which form the center of the building complex, are characterized by numerous small interconnecting rooms that follow a labyrinth-like layout and are flanked by long corridors on the eastern and western sides, respectively (Figure 4.32).

The southern enclosure wall limiting the whole building complex has been identified with some certainty, whereas the northern one remains unexcavated (see Figure 4.32). The overall layout suggests that it was to some extent carefully planned and not the result of consecutive additions in a random fashion. However, this does not exclude changes and additions to the initial plan of the internal rooms and walls, observable, for example, in the easternmost part (Area 3), which might have been transformed into magazines at some later time. ${ }^{2 \mathrm{I} 3}$

The internal architectural organization of the various rooms and corridors within the two central areas shows some striking features. The mud-brick walls have a thickness between $0.3 \mathrm{~m}$ and $0.6 \mathrm{~m}$ and join at right angles, with relatively precise orientation, to the cardinal points. Some of the rooms are arranged in such a way that they form interconnecting corridors in which the entrances are marked by slightly protruding doorjambs made of mud brick. These entrances face each other in the

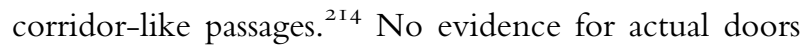
in form of thresholds or door sockets have been found in these passages, and it remains questionable whether they were ever closed. But there was certainly an organizing principle associated with these protruding doorjambs. ${ }^{2 \mathrm{IS}}$ Unlike the doorways between the corridors, the doorways connecting individual rooms are never situated in a direct axis. Instead, they are deliberately placed at the opposite corners of the narrow sides of the rooms and are therefore offset so that any person passing through one room cannot easily see into the following one (see Figure 4.32). ${ }^{216}$ These doorways and room arrangements take on a very complex form, which is further enhanced by the fact that the mud-brick walls were built at right angles to each other. However, the functions and purposes of these rooms and corridors have been difficult to establish because there is little evidence for any particular use or activities carried out inside them. 


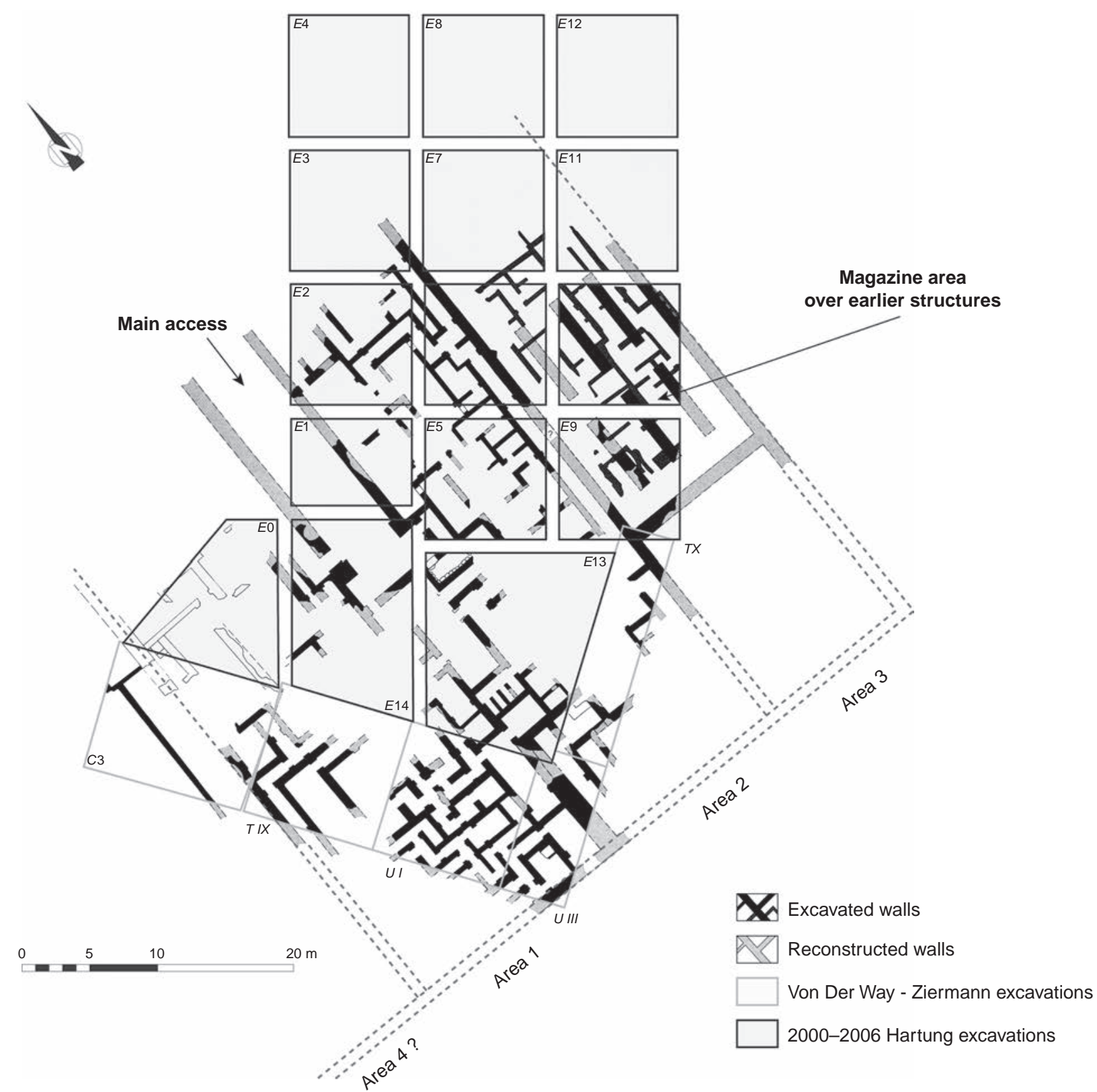

4.32. Early Dynastic building complex at Buto. By G. Marouard, after U. Hartung, "Der Fortgang der Untersuchungen am Tell von Buto: Ein 'Berg' an Informationen wartet auf die Entschlüsselung," in G. Dreyer, D. Polz, Begegnung mit der Vergangenheit - 100 Jahre in Ägypten, Mainz am Rhein 2007, 65, Abb. 82.

In Area I, one of the rooms contained a small deposit of about thirty clays sealings, with impressions left by cylinder seals that mention the names of several officials. ${ }^{217}$ The presence of the sealings is a strong indication that part of this Early Dynastic building complex functioned as an administrative center. Some architectural details, such as evidence for stone thresholds and limestone door frames as well as the recurring traces of painted wall plaster on the walls (large stripes of black, red, white, and yellow), indicate an official building, probably of palatial character. The structure would also have combined other aspects, such as being the residence for a high official and his household - a place where administrative tasks and significant storage would have been possible. Excavations in Area 3 revealed traces of the presence of a stone workshop and manufacturing facility in a first phase 
of use. These were then transformed into a large storage magazine tract, signifying the function as a centralized facility receiving goods from a wider region, maybe in the form of taxes that were collected here and sent back to the royal residence.

According to the pottery associated with this building complex, it was constructed sometime during the early First Dynasty and remained in use at least until the midSecond Dynasty, while some traces of final occupation dating to the late Second and early Third Dynasty show clear evidence for the building having been abandoned by the beginning of the Old Kingdom. ${ }^{218}$ Limited evidence for the late Second/early Third Dynasty activity is mainly present in the form of large pits that were used to destroy some of the mud-brick walls of this building complex, providing a good terminus ante quem for the use and functioning of the latter.

\subsubsection{Conclusions about the role and function of the building complex at Buto}

The precise function of this building complex as a whole has been difficult to establish, even though the expansion of the excavation over the past years has led to a much better understanding of it. The fact that most of the excavated rooms provided almost no further clue about their use and function, except for the examples outlined in the previous section, has led to several hypotheses about the building complex as whole, suggested by the excavators. The results of the earlier excavations during the I980s, which had focused on a relatively limited area (ca. $25 \mathrm{~m}$ by го $\mathrm{m}$ ), first led to a hypothesis that it might have functioned as a religious or funerary complex. The main argument for this interpretation was that certain architectural features have also been found in tombs and temples of the Early Dynastic and early Old Kingdom periods. ${ }^{219}$ This hypothesis was mainly based on the available structures for comparison, which belong entirely to the funerary sphere. Any evidence for secular buildings of official and administrative character and even palatial structures was almost completely absent in the archaeological record at that time, and even now the situation has not improved much. The palace-façade complex at Hierakonpolis was the only mud-brick building of possibly official and palatial character known to authors such as von der Way at the time of the publication of the first results from the excavations at Buto, but this was dismissed as unreliable evidence. ${ }^{220}$ Any interpretation or hypothesis for the role and function of such a structure within a larger settlement, as is the case with Buto and
Hierakonpolis, is still based on relatively little archaeological evidence. It is evident that the architecture and the overall layout of the Buto complex does not belong to any kind of regular domestic building but has an official character of some sort, which becomes especially clear when comparing it with the contemporary but much less structured buildings at Elephantine. ${ }^{221}$ The internal divisions into various areas might suggest a different function for each of them. This is further underlined by the evidence for secondary magazine installations in the westernmost area (Figure 4.32, Area 3). However, the two areas to the east of these installations show less differences, and Hartung suggested that the area adjacent to the magazine area might have been foremost a production area, which is linked to the evidence for food preparation and the manufacturing of stone vessels in at least two rooms there. Several elements near the gateway in the center of the building complex - such as the limestone elements at the doorways and the evidence for the careful wall preparation and decoration, which also characterize especially but not exclusively the rooms of Area I suggest that this was the most official part of the building. This seems to be further confirmed by the presence of sealings here. Considering these various elements that can be recognized within this large Early Dynastic building complex at Buto, a type of official building with administrative function - maybe even of palatial character - is thus far the most plausible interpretation regarding its function and purpose. ${ }^{222}$ The hypothesis that it had religious function has to be discarded. Many elements that can be found in the religious and funerary architecture in ancient Egypt were modeled to some extent on real life and official and private architecture.

Although this official building complex at Buto strongly suggests the presence of an important early urban center here, no further archaeological data concerning other elements of the Early Dynastic settlement have been excavated so far. Hartung interprets the two settlement concentrations that have been noted during the drill-core survey along the western part of the site as Pe and Dep, respectively. The northern one with the administrative complex would have been $\mathrm{Pe}$, while the smaller, southern outlier would have been Dep. ${ }^{223}$ The overall size of the Early Dynastic settlement has been estimated at about Io ha. ${ }^{224}$ The early history of the site has shown important trade contacts with the southern Levant during the settlement phase assigned to the Buto-Maadi culture, and this role most likely prevailed later on too. The ongoing excavations by the German Archaeological Institute will certainly shed more light on this site in the future. 


\subsection{THE EARLY DYNASTIC SETTLEMENT REMAINS AT ELEPHANTINE}

As can be seen from the various examples outlined in previous sections, relatively little evidence for the earliest settlements of urban character is currently available. By far the most details, including the opportunity to investigate the long-term evolution of a major regional center, come from the site of Hierakonpolis in Upper Egypt. Other settlements that certainly had a similar urban character - such as Elkab, Buto, and even Tell el-Farkha - are much less well known. Another settlement site with some urban characteristics but confined to a very limited space is the early town at Elephantine. For Early Dynastic period evidence, the evolution from the initial fortress foundation has been traced into the Old Kingdom, but only a few details are available for evaluating the character of the Early Dynastic settlement there (Figure 4.15). While there have been some good arguments for the fortress being a state foundation and part of an attempt to take control of the southern border region in Egypt, ${ }^{225}$ there is little evidence that allows for a more in-depth understanding of any of the urban characteristics outlined previously. Elephantine certainly had a fortified enclosure wall, which gradually developed from the fortress to include the extramural settlement that was emerging, but there is very little in terms of further details - such as official buildings of administrative character - on the eastern island. Evidence for a small local sanctuary comes from the niche between the granite boulders, which evolved into the later temple of Satet (Figure 4.I I). Few traces of an administrative building dating to the Third Dynasty were found on the western island, which at that time was separated by a water-filled depression from the eastern island and remained separated from the actual town. ${ }^{226}$ This is the earliest building at Elephantine that can be interpreted as an official administrative complex linked to the state, apart from the older fortress. However, there is no evidence for any larger official or residential area dating to the Early Dynastic period on the eastern island. ${ }^{227}$ The organization of small mud-brick buildings and open courtyards follows exactly the same agglutinated pattern in place during the later Dynastic times, without any clear demarcation for individual buildings or settlement quarters and defining streets or alleys (Figure 4.I5). In addition, the occurrence of clay sealings is not concentrated in any specific area; these were found in many places that cannot be distinguished by their architecture alone. These observations do not really categorize Elephantine as a fully developed urban center, but not as a village either. The precise character of Elephantine in terms of whether it can be considered another example of early urbanism in Egypt remains therefore questionable. It is quite likely that this settlement had a somewhat special function as a fortified border town in the First Cataract region and did not exhibit full urban features during the Early Dynastic Period.

\subsection{GENERAL CONCLUSIONS CONCERNING THE EMER GENCE OF URBAN FEATURES IN PREDYNASTIC AND EARLY DYNASTIC SETTLEMENTS}

The archaeological evidence shows that a dynamic development toward increased social complexity is clearly witnessed from the early Naqada II period onward. The site of Hierakonpolis is so far the best example for investigating the long-term evolution of an early urban center in Upper Egypt. From the early Naqada II period, it is possible to detect first signs for a proto-urban development among the installations that were part of the large and loosely organized settlement along the desert margins adjacent to the floodplain. The most prominent feature is the presence of large-scale food production areas along the margins of the settlement, such as the breweries, which have been excavated in several locations. One of the locations is along the principal wadi, which was used for an important elite cemetery of early chiefs or rulers with regional power at locality HK 6. Similarly, there is evidence for manufacturing at the pottery workshop at HK 29. These installations provide a first glimpse for the division of labor and centrally organized food production supplying a larger community. As outlined in this chapter, it is not possible to estimate with any precision how many inhabitants were fully or partially involved in agricultural activities and how many would have focused exclusively on food production and manufacturing of specific objects including pottery. As can be seen at Hierakonpolis, the size of the Early Predynastic settlement was considerable even if it cannot be termed urban yet. The decisive turning-point period in settlement development and early urbanism occurs at the transitional phase at the end of the Naqada II into the early Naqada III period. Suddenly, numerous urban features can be recognized from the archaeological data. This is the time when mud brick starts to be fully employed for domestic structures as well as tombs and small shrines and sanctuaries 
appear within the settlements - as can be witnessed at Tell Ibrahim Awad in the Delta and at the early ceremonial center at HK 29A at Hierakonpolis. Official buildings used by the elite as residences but also functioning on an administrative level can be recognized, such as the socalled Naqada residence situated on the Western Kôm at Tell el-Farkha, which dates to the same time frame. Complex trade relations between the Delta, southern Palestine, and possibly the Levant as well as Upper Egypt can be seen from the import of pottery vessels, foremost wine jars, which have also been found in large quantities as grave goods in tomb $U_{-j} j$ at Abydos. The administrative system that became so prominent in the later Early Dynastic Period starts to grow from regional to national level during the late Predynastic Period. It seems that the early Naqada III period is decisive for the appearance of urban society in Egypt, and the archaeological evidence sheds some light on the emergence of dynamic settlements displaying most of the features that can be considered urban during the following Early Dynastic period.

At Hierakonpolis, a gradual shift of settlement toward the floodplain as well as an increasing nucleation can be observed that seems to have occurred at other sites too for example, at Naqada. This shift has been attributed to some extent to climatic changes that caused lower and less-destructive Nile floods, allowing for the occupation of elevated river levees and geziras or any other higher ground available - for example, in the form of natural rock formations. While settlements became smaller in their overall size, which is to some extent related to the perennial flooding, they were also much more compact and exhibit densely constructed mud-brick buildings of an agglutinated design that leaves no space for major streets or even the recognition of individual buildings. This gives the impression of a kind of labyrinth-like layout. The only structures that are clearly distinguishable from the rest of the settlement are cult places and early shrines/temples as well as official/administrative building complexes that were marked by a perimeter wall. The finds as well as the architectural layout - especially the building complex marked by the palace-façade gate at Hierakonpolis - bear witness of an important hierarchy within the settlement and the presence of a strong elite controlling a wider region, which is paralleled in the nearby cemeteries. Evidence for administrative activities in the form of clay sealings and large storage facilities has also been discovered in conjunction with these large elite residences that during the later Dynastic period developed into the seat of the local mayor or governor. In addition, first traces of a small cult place within such a complex has been found at Hierakonpolis. Thus, the threefold function of these official complexes (residential, administrative, and cultic) is already to some degree present during the first two dynasties.

Little archaeological evidence exists for the overall size of these early urban centers because only small areas have been excavated at the sites. New fieldwork in the future will certainly shed more light on this issue and others discussed in this chapter.

\section{REFERENCES}

Adams, B. 1995. Ancient Nekhen. Garstang in the City of Hierakonpolis, Egyptian Studies Association Publication. New Malden: SIA Publishing.

Baba, M. 2008a. "More Big Pots: HK I IC Square B5 in 2008." Nekhen News 20:18-I9.

2008b. "Pottery-Making Tools: Worked Sherds from HK I I C Square B4, Hierakonpolis." In Egypt at Its Origins 2. Vol. 172, OLA, edited by B. Midant-Reynes and Y. Tristant, 7-20. Leuven/Paris/Dudley, MA: Peeters.

2009. "One More Big Pot: HK I IC Operation B in 2009." Nekhen News 21:23-24.

Barocas, C., et al. I989. "The Oriental Institute of Naples expedition to Petrie's South Town (Upper Egypt), I977I983: An Interim Report." In Late Prehistory of the Nile Basin and the Sahara, edited by L. Krzyzaniak and M. Kobusiewicz, 295-30 i. Poznan: Poznan Archaeological Museum.

Bunbury, J., and A. Graham. 2008. "There's Nothing Boring about a Borehole." Nekhen News 20:22-23.

Bussmann, R. 20Io. Die Provinztempel Ägyptens von der o. bis zur 11. Dynastie. Edited by W. Schenkel, A. Loprieno, and J. F. Quack. 2 vols. Vol. 3o, Probleme der Ägyptologie. Leiden: Brill.

Chlodnicki, M., and K. M. Cialowicz. 2005. "Tell El-Farkha (Ghazala): Season 2005." PAM I7:I43-I 54.

Cialowicz, K. M. 2007. "From the Residence to Early Temple: The Case of Tell el-Farkha." In Archaeology of Early Northeastern Africa. In Memory of Lech Krzyzaniak, edited by K. Kroeper, M. Chlodnicki, and M. Kobusiewicz, 9I7-934. Poznan: Poznan Archaeological Museum.

2009. "The Early Dynastic Administrative-Cultic Centre at Tell el-Farkha." BMSAES I 3:83-I23.

20II. "The Predynastic/Early Dynastic Period at Tell elFarkha." In Egypt before the Pyramids. The Origins of Egyptian Civilization. Vol. 33, OIMP, edited by E. Teeter, 55-64. Chicago: Oriental Institute.

Clarke, S. I92 I. "El-Kab and the Great Wall." JEA 7:54-79.

de Miroschedji, P. 200I. "Gaza et l'Egypte de l'époque prédynastique à l'Ancien Empire. Premiers résultats des fouilles de Tell es-Sakan.” BSFE I 52:28-52.

de Miroschedji, P., et al. 200 I. "Les fouilles de Tell es-Sakan (Gaza): Nouvelles données sur les contacts Égypto-Cananéens aux IVe-IIIe millénaires." Paléorient 27 (2):75-IO4. 
Dreyer, G. I986. Elephantine VIII: Der Tempel der Satet. Vol. 39, $A V$. Mainz am Rhein: Philipp von Zabern.

1998. Umm El-Qaab I. Das prädynastische Königsgrab U-j und seine frühen Schriftzengnisse. Vol. 86, AV. Mainz am Rhein: Philipp von Zabern.

Dreyer, G., and D. Polz. 2007. Begegnung mit der Vergangenheit: 100 Jahre in Ägypten: Deutsches Archäologisches Institut Kairo 19072007. Mainz am Rhein: Philipp von Zabern.

Eckmann, C., and S. Shafik. 2002. Die beiden Kupferstatuen des Pepi I. aus dem Tempel von Hierakonpolis in Ägypten. Vorbericht zur Restaurierung, Konservierung und technologischen Untersuchung zweier Grossplastiken aus dem Alten Reich, Jahrbuch des RömischGermanischen Zentralmuseums. Mainz: Verlag des RömischGermanischen Zentralmuseums.

2005. 'Leben dem Horus Pepi': Restaurierung und technologische Untersuchung der Metallskulpturen des Pharao Pepi I. aus Hierakonpolis Römisch-Germanisches Zentralmuseum, Forschungsinstitut für Vor- und Frühgeschichte: Monographien. Mainz; Bonn: Verlag des Römisch-Germanischen Zentralmuseums.

Eigner, D. 2003. "Tell Ibrahim Awad. A Sequence of Temple Buildings from Dynasty o to the Middle Kingdom." In Egyptology at the Dawn of the Twenty-First Century: Proceedings of the Eighth International Congress of Egyptologists, Cairo 2000, edited by Z. Hawass, I62-I70. Cairo: American University in Cairo Press.

Emery, W. B. I949. Excavations at Sakkara: Great Tombs of the First Dynasty. Cairo: Govt. Press.

Fairservis, W. A. J. I97I-I972. "Preliminary Report on the First Two Seasons at Hierakonpolis: Part I." JARCE 9:7-27.

1986. The Hierakonpolis Project. Season January to May 1981. Excavation on the Kom el Gemuwia. Poughkeepsie, NY: Vassar College.

Faltings, D. 1998. "Canaanites at Buto in the Early Fourth Millennium BC." EA I 3:29-32.

Friedman, R. F. I994. "Predynastic Settlement Ceramics of Upper Egypt: A Comparative Study of the Ceramics of Hemamieh, Naqada, and Hierakonpolis." PhD diss., Near Eastern Studies, University of California at Berkeley, Berkeley.

I996. "The Ceremonial Centre at Hierakonpolis Locality HK29A." In Aspects of Early Egypt, edited by J. Spencer, I6-35. London: British Museum Press.

I997. "The Ancient Egyptian View of Hierakonpolis." Nekhen News 9:I4.

I999. "Investigations in the Fort of Khasekhemwy." Nekhen News I I:9-I2.

2004. "Predynastic Kilns at HK I Ic: One Side of the Story." Nekhen News I6:I 8-I9.

2008a. "Excavating Egypt's Early Kings: Recent Discoveries in the Elite Cemetery at Hierakonpolis." In Egypt at Its Origins. Vol. 172, OLA, edited by B. Midant-Reynes and Y. Tristant, II57-II94. Leuven/Paris/Dudley, MA: Peeters.

2008c. "The Cemeteries of Hierakonpolis." Archéo-Nil I 8:9-. 2009. "Hierakonpolis Locality HK29A: The Predynastic Ceremonial Center Revisited." JARCE 45:79-I03.
Friedman, R. F., and L. McNamara. 2008b. "Return to the Temple Part II." Nekhen News 20:6-7.

Garstang, J. I907. "Excavations at Hierakonpolis, at Esna, and in Nubia." ASAE 8:I32-I 48.

Geller, J. I992. "From Prehistroy to History: Beer in Egypt." In The Followers of Horus. Studies Dedicated to Michael Allen Hoffman 1944-1990, edited by R. F. Friedman and B. Adams, I9-26. Oxford: Oxbow.

Hoffman, M. A., H. A. Hamroush, R.O. Allen, "The Environment and Evolution of an Early Egyptian Urban Center: Archaeological and Geochemical Investigations at Hierakonpolis," Geoarchaeology 2 (I) (I987), I-I3.

Harlan, J. F. I985. "Predynastic Settlement Patterns: A View from Hierakonpolis." $\mathrm{PhD}$ diss., Department of Anthropology, Washington University, St. Louis, MO.

Hartung, U. 2008. "Recent Investigations at Tell el-Fara'in/ Buto." In Egypt at Its Origins 2. Vol. 172, OLA, edited by B. Midant-Reynes and Y. Tristant, II95-I2I9. Leuven/ Paris/Dudley, MA: Peeters.

Hartung, U., et al. 2007. "Tell el-Fara'in - Buto. 9 Vorbericht." MDAIK 63, 69-I65.

Hartung, U., et al. 2009. "Tell el-Fara'in - Buto. Io. Vorbericht." MDAIK 65:83-I90.

Hassan, F. A., and R. G. Matson. I989. "Seriation of Predynastic Potsherds from the Nagada Region (Upper Egypt)." In Late Prehistory of the Nile Basin and the Sahara, edited by L. Krzyzaniak and M. Kobusiewicz, 302-315. Poznan: Poznan Archaeological Museum.

Helck, W. 1974. Die altägyptischen Gaue. Vol. 5, Beihefte zum Tübinger Atlas des Vorderen Orients. Reihe B, Geisteswissenschaften. Wiesbaden: L. Reichert.

Hendrickx, S. 2008. "Rough Ware as an Element of Symbolism and Craft Specialisation at Hierakonpolis' Elite Cemetery HK6." In Egypt at Its Origins. Vol. 172, OLA, edited by B. Midant-Reynes and Y. Tristant, 6I-85. Leuven/Paris/ Dudley, MA: Peeters.

Hendrickx, S., et al. 2009. "The I955 Excavation of an early Old Kingdom Storage Site at Elkab.” In Elkab and Beyond: Studies in Honour of Luc Limme, edited by W. Claes, H. De Meulenaere and S. Hendrickx, I-30. Leuven: Peeters.

Herbich, T. I998. "Magnetic Survey at Hierakonpolis." Nekhen News I0:I7-I 8 .

Hikade, T. 2004. "Urban Development at Hierakonpolis and the Stone Industry of Square $\mathrm{IoN}_{5}$ W." In Egypt at Its Origins. Studies in Memory of Barbara Adam. Vol. 138, OLA, edited by S. Hendrickx, R. F. Friedman, K. M. Cialowicz, and M. Chlodnicki, I8 I-I97. Leuven/Paris/Dudley, MA: Peeters. 2008. "Grand Designs in the Sacred Compound." Nekhen News 20: 4-5.

Hoffman, M. A. I97I-I972. "Preliminary Report on the First Two Seasons at Hierakonpolis. Part III: Occupational Features at the Kom el-Ahmar." JARCE 9:35-47.

I980. "A Rectangular Amratian House from Hierakonpolis and Its Significance for Predynastic Research." JNES 39 (2): I I9-I 37.

I982a. "Excavations at Locality 29." In The Predynastic of Hierakonpolis - An Interim Report, edited by 
M. A. Hoffman, 7-I4. Giza, Egypt; Macomb, IL: Cairo University Herbarium, Egypt.

I982b. The Predynastic of Hierakonpolis - An Interim Report, Egyptian Studies Association. Giza, Egypt; Macomb, IL: Cairo University Herbarium, Egypt.

I982c. "Settlement Patterns and Settlement Systems." In The Predynastic of Hierakonpolis, edited by M. A. Hoffman, I22-I38. Giza, Egypt; Macomb, IL: Cairo University Herbarium, Egypt.

Hoffman, M. A. I986. "A Preliminary Report on the I984 Excavations at Hierakonpolis." NARCE I 32:3-I4.

Hoffman, M. A. I989. "A Stratified Predynastic Sequence from Hierakonpolis (Upper Egypt)." In Late Prehistory of the Nile Basin and the Sahara, edited by L. Krzyzaniak and M. Kobusiewicz, 317-323. Poznan: Poznan Archaeological Museum.

Hoffman, M. A. I991. Egypt before the Pharaohs: The Prehistoric Foundations of Egyptian Civilization. Rev. and updated. ed. Austin: University of Texas Press.

Hoffman, M. A., et al. I986. "A Model of Urban Development for the Hierakonpolis Region from Predynastic through Old Kingdom Times.” JARCE 23:I75-I 87.

Hoffman, M. A., et al. I982. "Chapter I: Site Reports and Mapping Proejct." In The Predynastic of Hierakonpolis - An Interim Report, edited by M. A. Hoffman, 5-36. Giza, Egypt; Macomb, IL: Cairo University Herbarium and Western Illinois University.

Hoffman, M. A. H., et al. I987. "The Environment and Evolution of an Early Egyptian Urban Center: Archaeological and Geochemical Investigations at Hierakonpolis." Geoarchaeology 2 (I): I-I 3.

Kaiser, W. I958. "Zur vorgeschichtlichen Bedeutung von Hierakonpolis." MDAIK I6 (2):I83-I92.

Kaiser, W., et al. I993. "Stadt und Tempel von Elephantine, I9./20. Grabungsbericht." MDAIK 49, I33-I88.

Kaiser, W., et al. I995. "Stadt und Tempel von Elephantine, 2 I./22. Grabungsbericht." MDAIK 51:I00-I87.

Kaplony, P. I992. "Archaische Siegel und Siegelabrollungen aus dem Delta: Die Arbeit an den Siegeln von Buto." In The Nile Delta in Transition, 4th-3rd Millennium B.C.: Proceedings of the Seminar held in Cairo, 21.-24. October 1990 at the Netherlands Institute of Archaeology and Arabic Studies, edited by E. C. M. van den Brink, 23-30. Tell Aviv: E.C.M. van den Brink.

Kemp, B. I989. Ancient Egypt. Anatomy of a Civilization. Ist ed. London and New York: Routledge.

2000. "Soil (Including Mud-Brick Architecture)." In Ancient Egyptian Materials and Technology, edited by P. T. Nicholson and I. Shaw, 78-I03. Cambridge: Cambridge University Press.

2006. Ancient Egypt. Anatomy of a Civilization. 2nd ed. London and New York: Routledge.

Kopp, P. 2006. Elephantine XXXII. Die Siedlung der Naqadazeit. Vol. 118, $A V$. Mainz am Rhein: Philipp von Zabern.

Linseele, V., et al. 2009. "Special Animals from a Special Place? The Fauna from HK29A at Predynastic Hierakonpolis." JARCE 45 : IO5-I36.

McNamara, L. 2008. "The Revetted Mound at Hierakonpolis and Early Kingship: A Reinterpretation." In Egypt at Its
Origins. Vol. 172, OLA, edited by B. Midant-Reynes and Y. Tristant, 90I-936. Leuven/Paris/Dudley, MA: Peeters.

Midant-Reynes, B. 2000. The Prehistory of Egypt from the First Egyptians to the First Pharaohs. Oxford, UK; Malden, MA: Blackwell Publishers Ltd.

Midant-Reynes, B. 2003. Aux Origines de l'Égypte. Du Néolithique à l'émergence de l'État. Paris: Fayard.

2009. "Tell el-Iswid: Les campagnes 2006, 2007 et 2008." Archéo-Nil I 3:9-I 3.

Midant-Reynes, B., and N. Buchez. 20I4. Tell el-Iswid 2006-2009. Vol. 72, FIFAO. Cairo: Institut français d'archéologie orientale.

O'Connor, D. I989. "New Funerary Enclosures (Talbzirke) of the Early Dynastic Period at Abydos." JARCE 26:5 I-86.

I992. "The Status of Early Egyptian Temples: An Alternative Theory." In The Followers of Horus. Studies Dedicated to Michael Allen Hoffman 1944-199o, edited by R. F. Friedman and B. Adams, 83-98. Oxford: Oxbow Books.

Petrie, W. M. F. S. I905. Ehnasya. Vol. 26, Excavation Memoirs. London: Kegan Paul, Trench, Trübner \& Co.

Petrie, W. M. F. S., and J. E. Quibell. I896. Naqada and Ballas 1895. Vol. 1, BSAE. London: B. Quaritch.

Quibell, J. E., and F. W. Green. I9O2. Hierakonpolis. Part II. Vol. 5, BSAE. London: B. Quaritch.

Quibell, J. E., et al. I90o. Hierakonpolis. Vol. 4, BSAE, London: B. Quaritch.

Ritner, R. K. 2008. "Household Religion in Ancient Egypt.” In Household and Family Religion in Antiquity. The Ancient World: Comparative Histories, edited by J. Bodel and S. M. Olyan, I7I-I96. Oxford.

Rizkana, I., and J. Seeher. I989. Maadi III. The Non-Lithic Small Finds and the Structural Remains of the Predynastic Settlement. Vol. 8o, AV. Mainz am Rhein: Philipp von Zabern.

Rowan, Y., and J. Golden. 2009. "The Chalcolithic Period of the Southern Levant." Journal of World Prehistory 22 (I): I-92.

Seidlmayer, S. I996a. "Town and State in the Early Old Kingdom: A View from Elephantine." In Aspects of Early Egypt, edited by J. Spencer, I08-I27. London: British Museum Press.

Seidlmayer, S. J. I996b. "Die staatliche Anlage der 3. Dynastie in der Nordweststadt von Elephantine. Archäologische und historische Probleme." In Haus und Palast im Alten Ägyten, edited by M. Bietak, I95-2I4. Wien: Verlag der österreichischen Akademie der Wissenschaften.

Takamiya, I. H. 2004. "Kilns in Square A6: The Other Side of the Story." Nekhen News I9: I9-20.

2008. "Firing Installations and Specialization: A View from Recent Excavations at Hierakonpolis Locality I IC." In Egypt at Its Origins 2. Vol. 172, OLA, edited by B. MidantReynes and Y. Tristant, I87-202. Leuven/Paris/Dudley, MA: Peeters.

Tristant, Y. 2004. L'habitat prédynastique de la Vallée du Nil. Vol. 1287, BAR International Series. Oxford: Archaeopress.

Tutundzic, B. I989. “The Problem of Foreign North-Eastern Relations of Upper Egypt, Particularly in the Badarian Period: An Aspect." In Late Prehistory of the Nile Basin and the Sahara, edited by L. Krzyzaniak and M. Kobusiewicz, 255-260. Poznan: Poznan Archaeological Museum. 
van Haarlem, W. 2002. "The Ivory Objects from Tell Ibrahim Awad." EA 20:I6-I7.

van Haarlem, W., and T. Hikade. 2006. "Recent Results of Research at Tell Ibrahim Awad." In Timelines. Studies in Honour of Manfred Bietak, Vol. 149 (1), OLA, edited by E. Czerny, 389-198. Leuven/Paris,/Dudley, MA: Peeters.

Von der Way, T. I992. "Excavations at Tell el-Fara' in/Buto in 1987-1989." In The Nile Delta in Transition: 4 th-3rd Millennium BC, edited by E. C. M. van den Brink, I-IO. Tel Aviv: E.C.M. van den Brink.

I996. "Early Dynastic Architecture at Tell el-Fara'in - Buto." In Haus und Palast im alten Ägypten, edited by M. Bietak, 247-252. Wien: Verlag der österreichischen Akademie der Wissenschaften.

1997. Tell el-Fara'in -Buto I. Ergebnisse zum frühen Kontext. Kampagnen der Jahre 1983-1989. Vol. 83, AV. Mainz am Rhein: Philipp von Zabern.
Weeks, K. I97I-I972. "Preliminary Report on the First Two Seasons at Hierakonpolis: Part II: The Early Dynastic Palace." JARCE 9:29-33.

Wengrow, D. 2006. The Archaeology of Early Egypt, Cambridge World Archaeology. Cambridge: Cambridge University Press.

Winlock, H. E. I955. Models of Daily Life in Ancient Egypt from the Tomb of Meket-Re' at Thebes. Vol. 18, Publications of the Metropolitan Museum of Art Egyptian Expedition. New York: Harvard University Press.

Ziermann, M. I993. Elephantine XVI: Befestigungsanlagen und Stadtentwicklung in der Frühzeit und im frühen Alten Reich. Vol. 87, $A V$. Mainz am Rhein: Philipp von Zabern.

2003. Elephantine XXVIII: Die Baustrukturen der älteren Stadt (Frühzeit und Altes Reich). Grabungen in der Nordoststadt (11.-16. Kampagne) 1982-1986. Vol. 108, AV, Mainz am Rhein: Philipp von Zabern. 